\title{
Mixed Waste Paper to Ethanol Fuel
}

A Technology, Market, and Economics Assessment for Washington

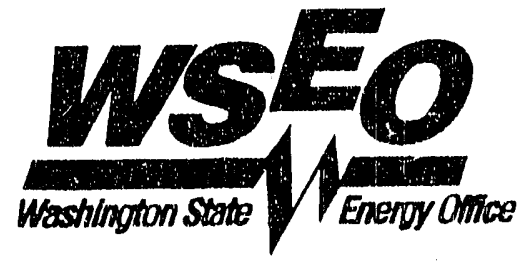

homo 


\section{Acknowledgements}

This work was co-funded by the Washington Department of Trade and Economic Development, the Washington State Legislature, and U.S, Department of Energy Bioenergy Program. We want to thank the Weyerhaeuser Corporation for their funding of the laboratory hydrolysis work.

We watnt to thank Richard Strickland of the Tennessee Valley Authority for arranging the carbohydrate analysis of the paper samples. The cooperation of Recycle America and Altar Recycling in providing samples is also appreciated. The data on ethanol fuel prices provided by Jim Peeples of Information Resources was most helpful. Preston HorneBrinc's review and comments on this report are much appreciated. Finally, we want to thank the people that gave their tine to talk to use about their projects and research.

\section{DISCLAIMER}

This report was prepared as an account of work sponsored by an agency of the United States This employees, makes any warranty, express or implied, or assumes any legal liability or responsibility for the accuracy, completeness, or usefulness of any information, apparatus, product, or bility for the accuracy, or represents that its use would not infringe privately owned rights. Reference herein to any specific commercial product, process, or service by trade name, trademark, manufacturer, or otherwise does not necessarily constitute or imply its endorsement, recommendation, or favoring by the United States Government or any agency thereof. The views and opinions of authors expiessed herein do not necessarily state or reflect those of the United States Government or any agency thereof.

Additional Copies of this report may be obtained from:

Energy Library

Washington State Energy Office

809 Legion Way S.E., Mail Stop FA-11

Olympia, Washington 98605-1211

91

WAOENG -05

January 1991 


\section{Table of Contents}

WAOENG--91-05

DE92 011828

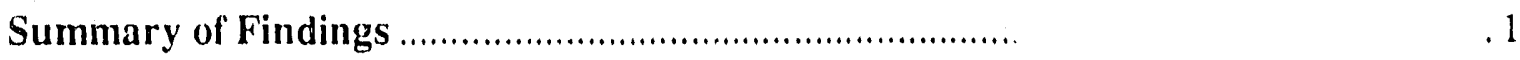

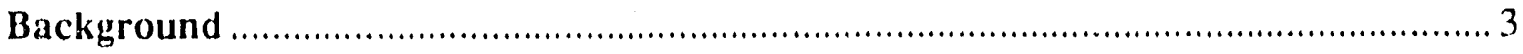

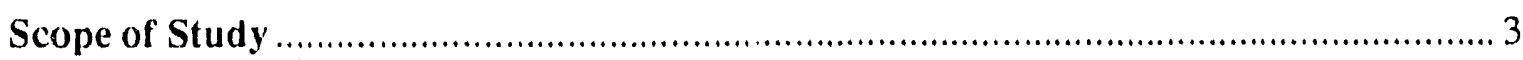

Scientific Basis for Converting MWP to Ethanol .................................................. 3

Composition of Mixed Waste Paper .................................................................... 3

Conversion of Paper to Ethanol ................................................................... 5

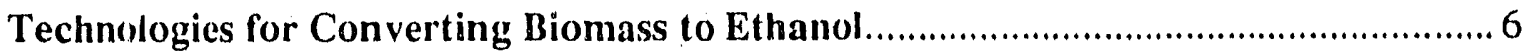

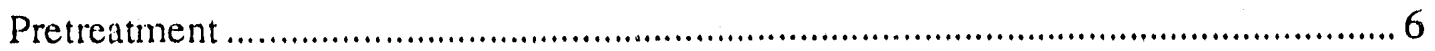

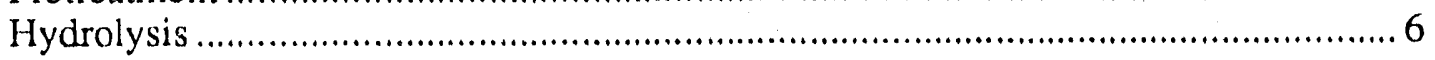

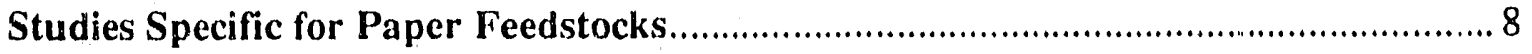

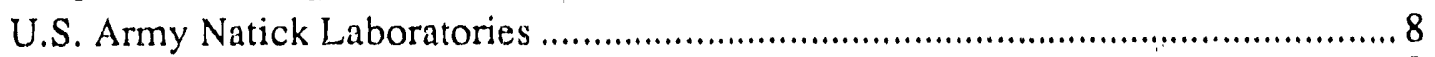

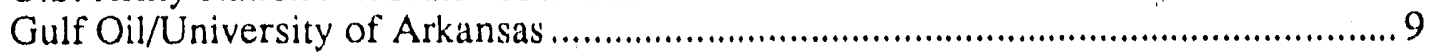

Procter \& Gamble Paper Company .................................................................. 9

Solar Energy Research Institute ....................................................................... 10

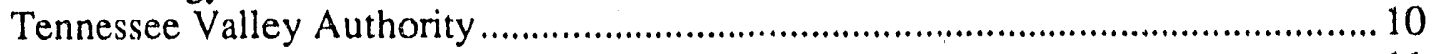

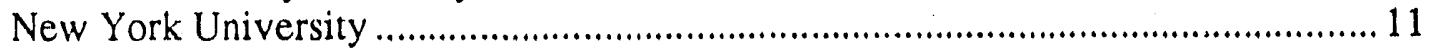

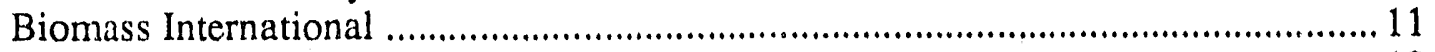

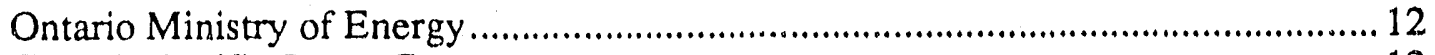

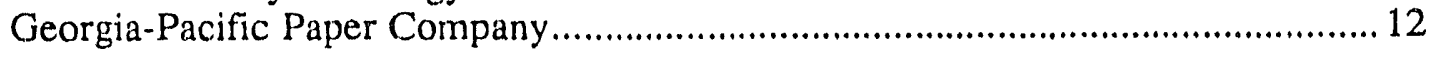

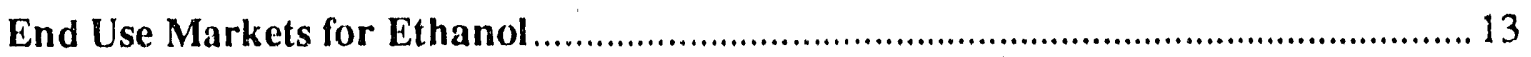

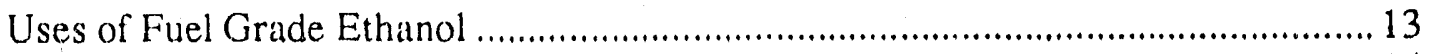

Fuel Ethanol Production and Consumption ..................................................... 14

Washington State Ethanol Markets .................................................................. 16

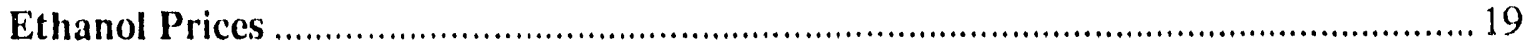

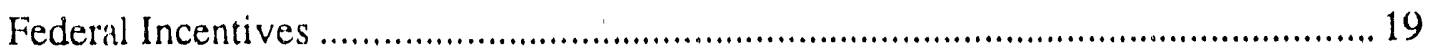

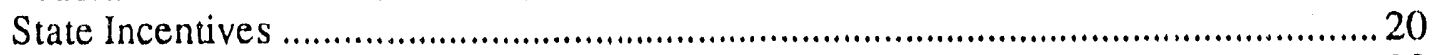

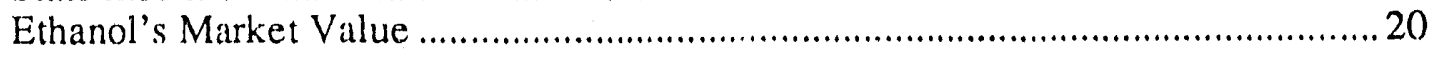

Economics of Ethanol Production from Paper ........................................................... 22

Tennessee Valley Authority Dilute Acid Hydrolysis ................................................ 22

Gulf Oil/University Arkansas Enzymatic Process ................................................. 24

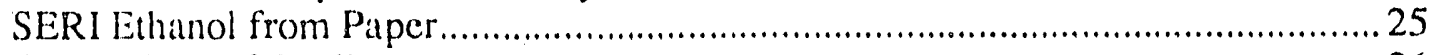

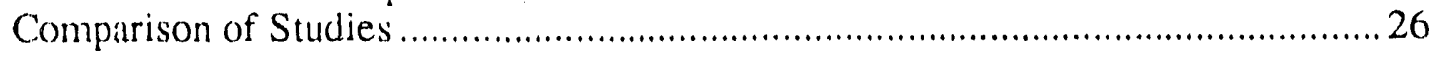

Economies of Ethanol Production from Mixed Waste Paper in Washington.............29

Cost of Producing Ethanol from Paper in Washington.........................................29

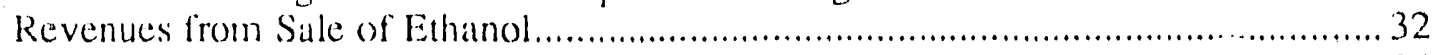

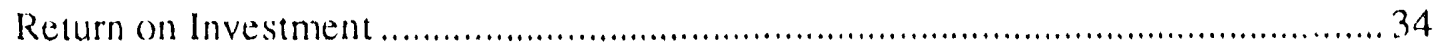

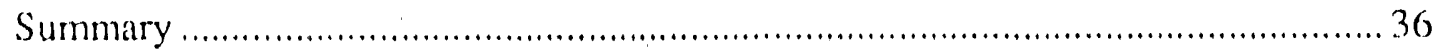




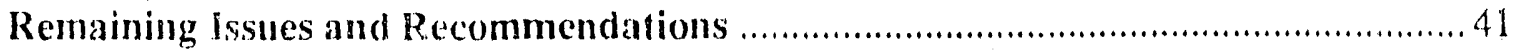

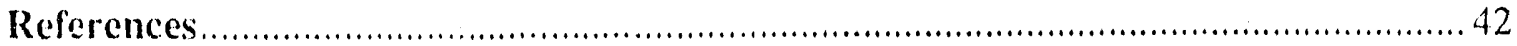

Appendix A. Record of Telephone Conversations and Site Visits

Appendix B. Carbohydrate Analysis of Mixed Waste Paper and Sludge Appendix C.. Enzymatic Hydrolysis Analysis of Mixed Waste Paper and Sludge

\section{List of Figures}

Figure 1. Carbohydrate Composition of Wood, Newsprint, and Ledger Paper........... 4

Figure 2. Ethanol Yields: Comparison of Technologies.........................................7

Figure 3. Effect of Pretreatment on Saccharification of Newspaper .......................... 8

Figure 4. U.S. Ethanol Fuel Production, 1979-1988 .............................................. 14

Figure 5. Washington State Ethanol Fuel Use, 1977-1989 ................................... 15

F' gure 6. Washington State Gasoline Use, 1979-1988 .......................................... 17

Figure 7. Historical Fuel Prices, Gassoline and Ethanol ........................................ 21

Figure 8. Major Operating Costs for Ethanol Production ........................................ 30

Figure 9. Production Cost Sensitivity to Feedstock Costs and Yields ..........................31

Figure 10. Production Cost Sensitivity to Capital and Depreciation Period.................. 31

Figure 11. Cumulative Probability Distribution of Gasoline. Prices ........................... 32

Figure 12. Effect of State Incentives on Ethanol Selling Prices ................................. 33

Figure 13. Sensitivity of ROI to Revenue and Expense Variables .............................. 35

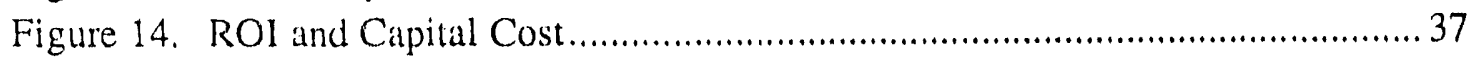

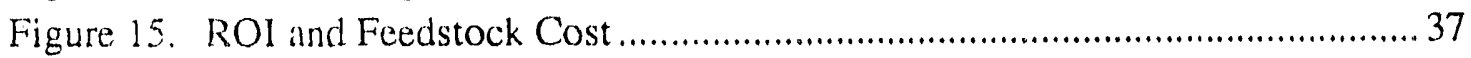

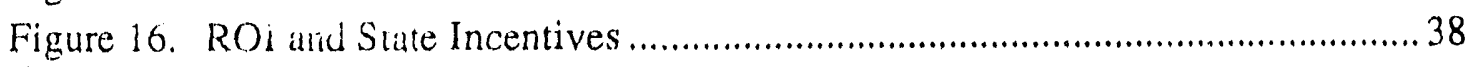

Figure 17. Major Capital Cost Items for Ethanol Production Facility ........................ 39

\section{List of Tables}

Table 1. Carbohydrate and Hydrolysis Analysis of Mixed Paper and Sludge ........... 5

Table 2. Composition of Potential Feedstocks from Pulp Mill Wastes..................... 9

Table 3. Composition and Ethanol Yichls from Newsprint and Ledger Paper ........ 10

Table 4. Carbohydratc Composition of RDF, Newsprint, and Corrugate ............... 11

Table 5. Capital Costs for 500 tpd WDF to Ethanol Facility ....................................22

Table 6. Production Costs for TVA Dilute Acid Hydrolysis of WDF .....................23

Table 7. Estimated Capital Costs for Gulf 2000 tpd Enzymatic Ethanol Facility .... 24

Table 8. Estimated Production Costs for Gulf 200 tpd Enzymatic Ethanol Facility. 25

Table 9. Ethanol Production Costs Using SERI Enzymatic Process ....................... 26

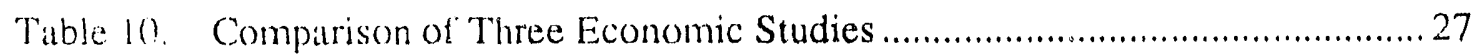

Table 11. Base Case Assumptions for Hypothetical Ethanol Plant in Washington .... 29

Table 12. Economic Factors Determining Profitability ............................................ 34

Table 13. Economic Advantages of Using Sludge as a Feedstock .......................... 40 


\section{Summary of Findings}

A recent report prepared for the Washington Committee for Recycling Markets entitled "Mixed Waste Paper Market Assessment" made several findings. They found that the demand for mixed waste paper in 1995 and 2000 would be essentially the same as current demand and that current demand in Northwest mills is extremely limited. They further stated that "unless the recycling rate for mixed waste paper increases to over 50 percent, it is unlikely that the state will meet it 50 percent recycling goal". The need for new markets was clearly established.

The Washington State Energy Office (WSEO) has been investigating alternative markets for mixed waste paper. Last year WSEO evaluated the economic and environmental feasibility of using mixed waste paper as a fuel in existing boilers. There were no environmental problems identified with the use of paper in properly designed combustors. However, the cost of processing the paper into a form usable in existing boiler exceeded its value to potential users. The need for a higher value-added product was identified and ethanol fuels offered several advantages including their strategic importance and a growing interest in "clean" transportation fuels.

The Department of Trade and Economic Development co-funded a study with the WSEO to evaluate the use of mixed waste paper for the production of ethanol fuels. Also, the Weyerhaeuser Company provided financial support.

The objectives of this study were to evaluate the use of mixed waste paper for the production of ethanol fuels and to review the available conversion technologies, and assess developmental status, current and future cost of production and economics, and the market potential.

This report is based on the results of literature reviews, telephone conversations, and interviews. Mixed waste paper samples from residential and commercial recycling programs and pulp mill sludge provided by Weyerhauser were analyzed to determine the potential ethanol yields. The markets for ethanol fuel and the economics of converting paper into ethanol were investigated.

The findings of this report are the following:

1. Technologies available for converting MWP to ethanol fuel include: dilute acid hydrolysis, concentrated acid hydrolysis, and enzymatic hydrolysis.

2. Approximately 70 gallons of ethanol fuel can be produced from one ton of mixed waste paper.

3. Government research laboratories have only recently begun investigating the conversion of paper tc ethanol. Previous work has been directed to converting woody feedstocks to ethanol.

4. Private industry is showing interest in ethanol production from paper feedstocks both as a market for paper collected by recycling programs and as a profitable venture.

5. The cost of production is sensitive to the size of the facility. Larger facilities offer lower production costs mainly due to lower capital cost and labor costs per gallon of production. 
6. Currently 6.5 million gallons of ethanol fuel is sold in Washington. The market potential is much larger and currently constrained by lack of supply.

7. The use of ethanol blended fuels reduck carbon monoxide vehicle emissions.

8. The selling price of ethanol is equal to the wholesale price of gasoline plus federal and state incentives less marketing costs. The average price for ethanol over the past thirteen years was $\$ 1.40 /$ gallon.

9. Federal incentives, equal to $\$ 0.054 /$ gallon of blended fuel, have been extended to December 31,2000 . State incentives, equal to $\$ 0.034$, are scheduled to sunset December 31, 1992.

10. The capital cost for a facility to process all the mixed paper generated in the Puget Sound area is estimated at $\$ 53$ million.

11. If gasoline prices show the same fluctuation in prices that they showed in the past thirteen years, there is a fifty percent probability that the after tax return on investment would exceed sixteen percent.

12. Existing facilities offer several advantages as market entry points for the production of ethanol fuel from mixed waste paper. 


\section{Background}

Recycling is one of the key elements in an integrated solid waste management program. A successful recycling program requires several components: convenient collection service, continuing education and promotion, and a market for the collected materials. Government agencies have assumed much new responsibility for making collection services available and government is also active in educational programs. However, government has a much more difficult challenge in helping to encourage the development of markets for materials collected by recycling programs.

The domestic market currently have or are building the capacity to use all the glass, newsirint, aluminum, tin cans, and corrugate materials that are collected. Mixed waste paper (MWP) is the one commodity that has currently limited domestic markets and the one without any clear future markets. A majority of the mixed paper collected in Washington is exported and the selling price is decreasing. Indeed, most end-use markets are private sector industrial manufacturers.

The Washington State Energy Office has been investigating alternative markets for mixed waste paper. WSEO evaluated the economic and environmental feasibility of using MWP as a fuel in existing boilers. MWP was found to have properties similar to wood and coal fuels and would not pose an environmental problem if burned in a properly designed combustor. However, the current cost of processing the MWP into a fuel is greater than the value of the fuel to potential users.

The Department of Trade and Economic Development co-funded a study with the Washington State Energy Office to evaluate the use of mixed waste paper to produce a higher value energy product, ethanol fuel. The Weyerhaeuser Company provided financial support.

\section{Scope of the Study}

The purpose of this study is to make a preliminary assessment of the potential for converting mixed waste paper into ethanol fuel. The study assesses the technical, economic, and environmental questions. The report is divided into three major sections. The first section reviews the science and available technologies, comparing their advantages and disadvantages. The second section looks at the market potential, both current and future, for ethanol fuel and its value in the market place. The final section focuses on the cost of producing ethanol from mixed waste paper and the projected profitability of facilities in Washington.

The time frame and budget for this study limited it to a review of the scientific and technical literature, telephone interviews with current investigators in the United States and Canada, and discussions with the ethanol fuel marketing organizations. Laboratory analysis of samples collected from residential curbside programs, commercial recycling programs, feedstocks, and pulp mill sludge provide some information specific for Washington.

\section{Scientific Basis for Converting MWP to Ethanol}

\section{Composition of Mixed Waste Paper}

Mixed waste paper is a heterogeneous mixture consisting of box board from cereal and shoe boxes, magazines, junk mail, some newspaper, and other varieties of paper. Previous investigations determined the elemental composition of mixed waste paper (Lyons and Kerstetter, 1989). Elemental composition is used to calculate the products of combustion when the material is burned. When mixed waste paper is used to make ethanol the carbohydrate content is important. 
Paper is made from wood and wood is made from carbon dioxide and water. The carbon dioxide and water make sugars that then combine into larger molecules or polymers. The major chemical components of wood are cellulose, hemicellulose, and lignin. Cellulose is a polymer made from glucose sugar molecules forming a crystalline material with high chemical stability.

Hemicellulose is a polymer made from xylose sugars, glucose sugars, and organic acids.

Hemicellulose is not crystalline and is easily decomposed. Lignin, the non-carbohydrale portion of the cell wall, is a complex phenolic polymer not convertible to sugars.

Figure 1 shows a comparison of the composition of wood, newsprint, and ledger paper (SERI, 1990). Wood contains about 45 percent cellulose, 20 percent hemicellulose, and 25 percent lignin, with smaller quantities of ash and other organic molecules. The chemical composition of paper produced from wood depends upon the type of pulping process used. Newsprint is balsically ground wood and contains 52 percent cellulose, 5 percent hemicellulose, 25 percent lignin and other materials. Office paper is produced from wood by a chemical process which rernoves most of the lignin and hemicelluiose. Office paper has a composition of 71 percent cellulose, 6.5 percent hemicellulose and 0.4 percent lignin.

Mixed waste paper collected by residential and commercial recycling programs is available at relatively low costs. Sludges from pulp and paper mills are also available at low or negative costs. Samples were collected and analyzed for sugar content. The residential sample was taken from the City of Olympia curbside program, the commercial sample from state agency recycling program run by All Star Recycling in Olympia, and the sludge sample was provided by Weyehaeuser. The Tennessee Valley Authority volunteered to do the laboratory analysis. Table 1. shows the results. The glucose and mannose can both be converted to ethanol by ordinary yeast. The xylose and other materials would be used as fuel. Residential mixed waste paper contains paper that has not been treated as thoroughly as office ledger paper in the pulping process and thus has a higher lignin and inerts content. Commercial mixed waste paper is higher in fermentable sugars and would be the preferred feedstock. The enzyme hydrolysis of these samples was performed at Mycotech, Inc., where the cinnversion of cellulose to glucose was determined and the ethanol yield was calculated. These results are in agreement with the data from SERI on newspaper and office paper.

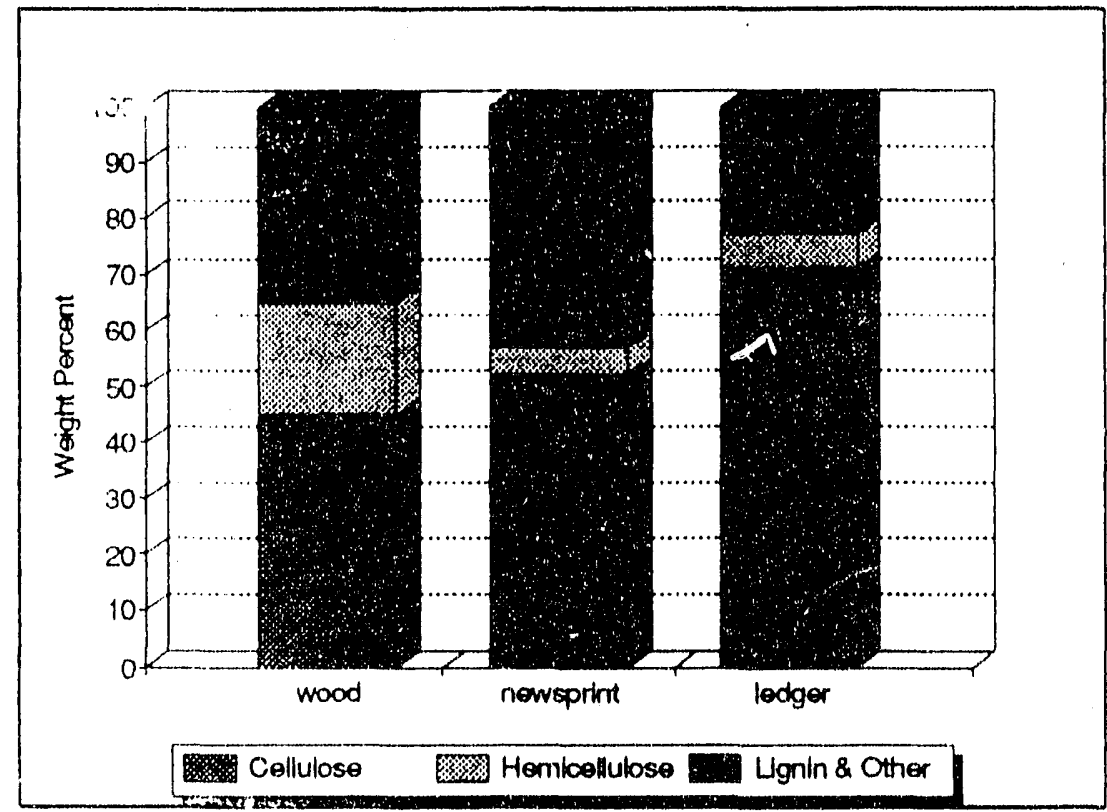

Figure 1. Cellulose, hemicellulose, and lignin composition of wood, newsprint, and ledger paper. (SERI, 1990) 
Table 1

Sugar Analysis of Mixed Waste Paper and Pulp Sludge

\begin{tabular}{lrrr} 
Component & Residential & Commercial & Sludge \\
\hline Glucose, \% & & & \\
Mannose, \% & 55.97 & 68.63 & 22.08 \\
Xylose, \% & 5.61 & 7.76 & 5.70 \\
Lignin/inerts, \% & 8.32 & 12.35 & 4.03 \\
Ethanol yield, gal/ton & 30.10 & 11.26 & 68.19 \\
& 60.00 & 74.00 & 25.00
\end{tabular}

The theoretical or maximum amount of ethanol that can be produced from cellulose is determined by the chemistry of the conversion processes. Each pound of cellulose can yield 1.11 pounds of glucose. Each pound of glucose can yield 0.511 pounds or 0.0774 gallons of ethanol. The theoretical yield of ethanol from one pound of cellulose is 0.086 gallons. The theoretical yields from one ton of newspaper, ledger paper, mixed residential paper and mixed commercial paper are $89,122,95$, and 118 gallons of ethanol, respectively.

Since no conversion process is 100 percent efficient, the actual yields will be less than theoretical. Typical cellulose to glucose conversions are 70 percent efficient and the conversion and recovery of ethanol from glucose is 90 percent efficient. Thus, the expected yields ivould be 63 percent of the theoretical yields.

\section{Conversion of Paper to Ethanol}

There are three basic steps in converting paper or wood into ethanol. First is the separation of cellulose, hemicellulose, and lignin. This is done by a pretreatment process that mechanically reduces the feedstock into small pieces and then chemically reacts the material producing a mixture that can be separated into cellulose, hemicellulose, and lignin streams. Cellulose is the major component of paper and it must be broken down (hydrolyzed) into glucose before it can be fermented to ethanol. This can be accomplished by use of acids or by enzymes. The hemicellulose is generally converted into xylose sugars during the initial pretreatment steps. Lignin is separated but not changed during pretreatment.

The second step in ethanol production is conversion of sugars into ethanol. Ordinary yeast can be used to convert glucose and other six carbon sugars to ethanol. Yeast will not convert xylose, a five carbon sugar, into ethanol and different organisms must be used. In general, the xylose sugars would not be fermented if paper were the feedstock because of their relatively low concentrations in paper. If wood were the feedstock, it would be economic to convert the xylose to ethanol.

The final step in producing ethanol fuel is distillation. This process concentrates the ethanol by removing the water. The solution formed by fermentation contains about six percent ethanol while the final ethanol fuel contains 100 percent ethanol.

The lignin contained in the paper is recovered and used as a fuel to generate steam and electricity to run the equipment. In general there is enough lignin to provide all the process energy needs. 


\section{Technulogies Converting Biomass to Ethanol Fuel}

The scientific principals involved in converting wood and wood derived products to ethanol were outlined above. There is currently no one particular process or technology that has proven itself to be substantially better than the alternatives. The major tradeoffs involve choice of the pretreatment method to separate the components and hydrolysis method to convert the carbchydrates into sugars. Most research effort has been devoted to using wood and agricultural residues as a feedstock. The experience gained with these materials is appliciable to paper feedstocks. In fact paper is often thought of as a preferred feedstock. because it has already been partially processed.

\section{Pretreatment}

The process of making pulp from wood is one of pretreatment, or separating the cellulose fibers from the other components of the wood. Thus, pretreatment options have been thoroughily investigated for the production of pulp and paper from wood. Work is continuing on the pretreatment of wood and other biomass feedstocks for ethanol production. A limited amount of work has been performed on pretreatment of paper for ethanol production.

Pretreatmen methods that have been tried for conversion of wood or other biomass feedstocks to ethanol include mechanical roller mills, steam explosion, acid pre-hydrolysis, alkali treatment, organic solvents, and radiation. The selection of one over the other is a balance between conversion efficiency or yield of separated products and the capital and operating costs for the particular technology. Just because one method gives a better yield does not mean that it is the preferred technology. Basically if the marginal cost is greater than the marginal return than the technology will not be chosen.

\section{Hydrolysis}

Hydrolysis is the addition of water to the polymer molecule and breaking it down into simple sugars. There are many methods that have been tried for both wood and other biomass feedstocks. Paper has also been studied to a fair degree. More work has been done on the hydrolysis of paper than has been done on pretreatment of paper.

Many of the pretse:" ment methods, besides separating the cellulose, hemicellulose, and lignin, also hydrolyze the hemicellulose to xylose. Therefore, xylose does not require further hydrolysis. It may require additional processing steps since ordinary yeast do not convert xylose to ethanol. However, since paper is low in xylose, these steps would probably not be pursued since they would not be economically justified.

Cellulose must be converted to glucose before it can be fermented to ethanol. Cellulose occurs in a crystalline form and is more difficult to hydrolyze. The crystalline structure must first be disrupted and than the chemical bonds broken to separate the individual glucose molecules. There are three basic technologies available: concentrated acid hydrolysis, dilute acid hydrolysis, and enzymatic hydrolysis.

Acid can be used to break cellulose down into glucose. Dilute acids require higher temperatures to atfect the conversion. Unfortunately, the glucose molecules themselves will decompose if held at high temperature under acidic conditions. The trick is to break down the cellulose to glucose before the glucose is decomposed and to still produce a solution. with a high n! were concentration. Various methods have been used including processes called plug fow. percelation, and progressing batch reactors. Concentrated acids result in high con the acids or recovery of the acids are expensive. 
Each method offers some advantage over the others but also carries some disadvantages. The pluses and minuses are usually involved in the sugar yield, the operating costs, the sugar concentration, and the capital costs for the equipment. A compurison of the various acid hydrolysis methods, using wood as the feedstock has recently been carried out by the Solar Energy Research Institute (Wright, 1986).

Enzymes can also be used to hydrolyze cellulose to glucose. These enzymes are called cellulases and are produced by fungi, bacteria, and other organisms. The advantages they have over acid hydrolysis are the mild operating conditions and little degradation of glucose. These advantages translate into lower capital costs for reactor vessels and higher yields. Cellulases decompose cellulose in three steps. First is a splitting of the cellulose chain by endoglucanase. Next, exo-glucanases split the chain into cellobiose units (two glucose molecules linked together). Finally, beta-glucosidase splits the cellobiose units into glucose. The glucose can than be fermented into ethanol.

Enzyme technologies offer the advantage of being able to combine hydrolysis and fermentation in the same vessel, a process called simultaneous saccharification and fermentation or SSF. That means cellulase enzymes and yeast are present together. As the glucose is released from the cellulose it is fermented to ethanol by the yeast. This offers an added advantage because cellobiose can inhibit the activity of exo-glucanase and glucose can inhibit the action of beta-glucosidase. By removing these compounds as they are formed their inhibitory effect is reduced.

Figure 2 shows a comparison of expected ethanol yields from woody feedstocks assuming only the cellulose portion was converted to ethanol. The strong acid and enzymatic processes give better yields and thus make more efficient use of the feedstock. This is especially important if feedstock costs are high. The yield for concentrated $\mathrm{H} 2 \mathrm{SO} 4$ represents 71 percent of the theoretical conversion of cellulose to ethanol, assuming a 50 percent cellulose content.

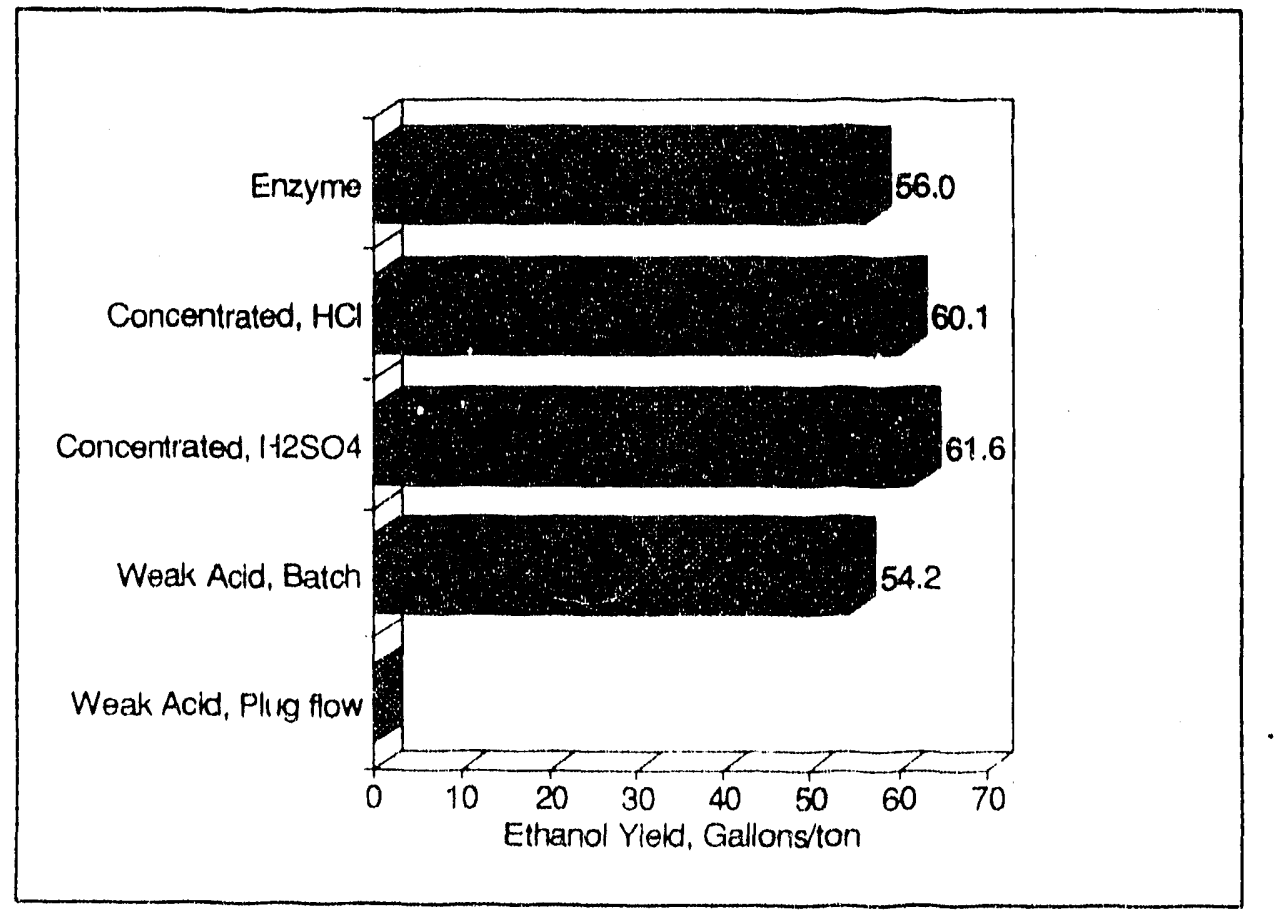

Figure 2. Comparison of ethanol yields from woody feedstocks using different hydrolysis technologies. (Wright, 1986) 


\section{Studies Specific for Paper Feedstocks}

Six published studies were identified that evaluated waste paper as feedstock for conversion to ethanol fuel. Two of the studies looked at a dilute acid hydrolysis process and four looked at enzymatic hydrolysis. Three other paper to ethanol activities were identified and contacted by telephone.

\section{U.S. Army Natick Laboratories}

Dr. E. Reese of the U.S. Army Natick Laboratories in the 1940's researched the degradation of cellulose. The Army's concern was the disintegration of cloth and tents in jungle environments. Research showed that fungal organisms were producing enzymes that degrade cellulose to glucose. While this is a problem for troops in the field it also offered another way to produce glucose from biomass resources.

In 1975 Natick researchers reported sugar yields obtained by converting several different types of industrial paper waste using enzymatic hydrolysis (Andren, 1975). They measured the conversion yields compared to newsprint conversion. Samples of pulp, shredded government documents, and pulp mill waste all gave higher conversion to sugars than did the newsprint. The effect of various pretreatment methods on the conversion of newsprint were also reported. The importance of pretreatment methods is shown in Figure 3 where conversion yields ranged from 26 percent for boiled water pretreatment to 70 percent for a pot milling pretreatment.

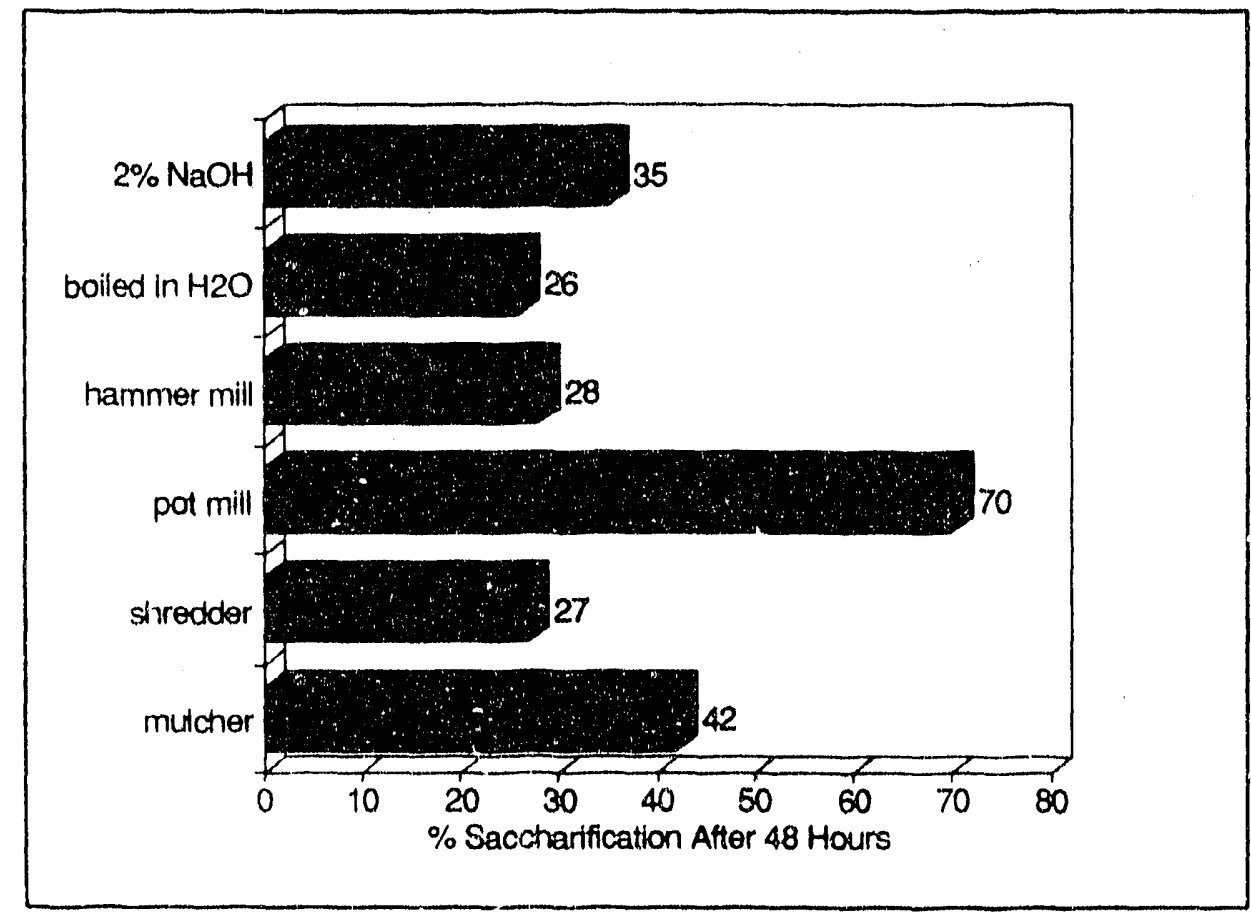

Figure 3. Effect of pretreatment methods on saccharification of newsprint. (Andren, 1975) 


\section{Gulf Oil and University of Arkansas}

Gulf Oil Chemical Company supported laboratory and pilot plant research on the conversion of cellulosic feedstocks to ethanol. In 1976, they started operation of a 1 ton per day (tpd) pilot plant that used enzymatic hydrolysis to convert various biomass materials into ethanol. The facility was the first to demonstrate the simultaneous saccharification and fermentation process at a pilot plant scale. In 1979 Gulf donated the patents and pilot plant to the University of Arkansas. A 50 tpd facility was designed to provide detailed process engineering data for a commercial scale plant. The 50 tpd plant was never built.

The Gulf and University of Arkansas work demonstrated some of the advantages of enzymatic hydrolysis. They also investigated several materials that may be available in Washington. Table 2 shows the composition of cellulosic materials studied by Gulf. The cellulose content and thus the potential ethanol yields look good. Gulf assumed a yield of 71 gallons of ethanol per ton of feedstock (Emert and Katzen, 1979). Cost estimates were made for a commercial sized 2000 tpd facility using pulp mill sludge and paper from municipe' solid waste.

Table 2

\section{Composition of Potential Feedstocks from Pulp Mills}

Percent Comcosition, dry basis

\begin{tabular}{lcccc} 
Material & Cellulose & Lignin & Ash & ADS \\
\hline Primary clarifier sludge & 48 & 8 & 18 & 26 \\
Secondary clarifier sludge & 21 & 4 & 55 & 20 \\
Deinking sludge & 29 & 4 & 38 & 29 \\
Super fines & 62 & 6 & 9 & 24 \\
Digester rejects & 65 & 13 & 1 & 21 \\
Digester fines & 64 & 9 & 5 & 22 \\
RDF & 61 & 9 & 8 & 22
\end{tabular}

\section{Procter \& Gamble Paper Company}

Procter \& Gamble Paper Company recently evaluated the SSF process to produce ethanol from their pulp and paper mill waste fiber (Easley, et al, 1989). Testing was done in the laboratory as well as at a 2,600 gallon pilot plant fermenter. Various fiber pretreatment were also evaluated. The motivation for the studies is the high costs ( $\$ 80$ to $\$ 100$ per wet ton) for land filling these waste materials.

The most cost effective pretreatment method was a combination of double disk refining and low level $(0.5 \%)$ caustic addition. The bench scale ethanol yields were between 86 and 99 gallons per ion. The pilot scale optimization studies indicated yields of 86 to 94 gallons per ton. There were no economic evaluations presented. 


\section{Solar Energy Research Institute}

The Solar Energy Researcli Institute (SERI) recently released a draft report on the production of ethanol fuel from biomass resources in the mid-western section of the United States (SERI, 1990). Waste paper was one of the feedstocks considered.

SERI has been actively involved in research to improve the economics of converting biomass into ethanol. Their work ranges from basic research into the genetic manipulation of yeasts to pilot work on mixing of wood slurries. They investigated both acid hydrolysis and enzymatic hydrolysis methods for woody materials. They are just beginning to look at waste paper as a feedstock.

Their recent study considered the enzymatic hydrolysis of waste paper that had properties midway between newsprint and ledger paper. They determined the cellulose composition and ethanol yields for these two materials. The results are shown in Table 3.

Table 3

\section{Composition and Ethanol Yields \\ from Newsprint and Ledger Paper}

\begin{tabular}{lrc} 
Measurement & Newsprint & Ledger Paper \\
\hline Cellulose, wt \% & 52.0 & 71.3 \\
Xylose, wt. \% & 5.0 & 6.5 \\
Lignin, wt. \% & 25.0 & 0.4 \\
Ash, wt. \% & 0.5 & 0.5 \\
Moisture, wt. \% & 7.0 & 7.0 \\
Ethanol, gal/ton & 47.0 & 80.0
\end{tabular}

The relatively low xylose levels support the notion that it would not be economically feasible to ferment xylose to ethanol if paper were the feedstock. SERI did an economic evaluation for commercial scale facilities converting paper to ethanol. The results are presented in the section on economics.

\section{Tennessee Valley Authority}

The Tennessee Valley Authority has been investigating the conversion of biomass to ethanol for the past decade. They focused on wood and agricultural field residues as feedstocks and concentrated and dilute acid hydrolysis conversion technologies. They have recently begun looking at waste paper as a feedstock. The carbohydrate composition of RDF, newsprint, and corrugate are shown in Table 4. Their laboratory work using dilute and hydrolysis gave ethanol yields of 30 gallons per ton of RDF. They are just beginning to work on paper feedstock. 
Table 4

Carbohydrate Composition of RDF, Newsprint, and Corrugate

\begin{tabular}{lrrc} 
Component, wt. \% & RDF & Newsprint & Corrugate \\
\hline & & & \\
Glucose & 64.9 & 56.0 & 68.5 \\
Mannose & 8.9 & 9.0 & 9.5 \\
Xylose & 12.0 & 8.5 & 10.4 \\
Lignin \& other & 14.2 & 26.5 & 11.6
\end{tabular}

\section{New York University}

Professor Barry Rugg has been working on a dilute acid hydrolysis process that uses a modified screw extruder. The extruder allows accurate control of temperature, pressure, and residence time, all of which are critical in dilute acid hydrolysis processes. Rugg has been working to develop this process since the mid 1970's. A one ton per day pilot plant was constructed with support from the Environmental Protection Agency. Using a RDF type of feedstock, glucose yields of 50 percent were achieved. That is equivalent to an ethanol yield of 47 gallons per ton of RDF.

\section{Biomass International}

Biomass International is a privately funded organization located in Ogden, Utah. They have been working on conversion of biomass feedstocks to ethanol fuel for the past decade using a concentrated acid process.

Their 56 tpd MSW to ethanol demonstration pilot plant was 50 percent complete as of December 1990. They expect to begin accepting material within six months. The 56 tpd represents the modular size for their commercial facilities.

They will produce an RDF type of nuaterial from mixed garbage that will then undergo concentrated hydrochloric acid $(\mathrm{HCl})$ hydrolysis. They contracted with a Delaware company to provide the acid recovery equipment. They expect an 85 percent recovery of fermentable sugars. This should give a yield of 40 gallons of ethanol per ton of "as received" MSW.

The demonstration unit is projected to cost $\$ 4$ million. Initially, they had planned to spend $\$ 1$ million. They are working to obtain funds for completion of both the demonstration plant and the commercial plant (500 tpd).

Biomass International has an agreement with Weber County, Utah to process all the counties MSW, approximately 550 tpd. The county will pay a tipping fee of $\$ 11 /$ ton and will provide land for the processing facility free of charge. Biomass will separate the MSW intc a fermentable fraction, a recyclable fraction, and a disposal fraction.

This facility, if successful, will be the only one in the country with a pilot plant large enough to obtain good engineering data for the scale up to large facilities. There are several critical features of their facility that must be demonstrated. One is the ability to recover a substantial proportion of the $\mathrm{HCl}$. Second is the materials compatibility with the residue $\mathrm{HCl}$ that will be left. 


\section{Ontario Ministry of Energy}

The Ontario Ministry of Energy recently entered into a jointly funded project with two private Canadian companies to investigate the conversion of waste paper to ethanol. The purpoie of the investigation is to compare the ethanol yields from paper samples using acid hydrolysis and an enzymatic hydrolysis technology. Pretreatment will be by a steam explosion process.

Biohol, a subsidiary of Diversified Industries, will test a plug flow acid hydrolysis process. They plan to modify a commercial system that is currentiy used to convert starch material into glucose. The principal objective is to get a higher concentration of the paper slurry to move through the reactor. Diversified Industries owns several pulp mills and is interested in evaluating these technologies for their own use.

Stake Technology is the other company participating in the study. They developed the steam explosion pretreatment method for wood feedstocks. They recently received a patent that would apply their technology to de-inking paper. Stake will take the pretreated paper and subject it to enzymatic hydrolysis. They are using an enzyme that was developed by the French Petroleum Institute. Mohawk Oil in Canada is following their progress but has not committed any funds at this time.

The project is scheduled to be completed by November 1991. At that time they hope to be able to decide which hydrolysis process, acid or enzyme, is "best". Both Stake and Biohol have stated that they will then pursue further work on the selected technology.

\section{Georgia-Pacific Paper Company}

No one is currently producing cthanol fuel from waste paper as a commercial venture. Georgia-Pacific, in Bellingham, Washington, is the only facility in the United States producing ethanol from cellulosic feedstock. They produce ethanol from the waste pulping liquors that are generated when wood in converted into pulp. They are unique for two reasons. First, their pulping process does not reuse the pulping liquurs and would have to be undergo treatment before they could be discharged. Second, the conversion process was financed by the U.S. government during World War II to provide a source of ethanol that could be used to produce synthetic rubber. 


\section{End Use Markets for Ethanol}

The ethanol fuel industry emerged during the oil market turbulence of the late 1970's. Spiraling oil prices and supply vulnerability spurred the Federal government to support the development of a domestic renewable fuel industry. As a result, the ethanol fuel industry was born and a blend of 10 percent ethanol with 90 percent gasoline was introduced to the U.S. gasoline market. With time, ethanol expanded beyond this market and has been used by the petroleum industry for both octane enhancement and fuel enleanment.

\section{Uses of Fuel Grade Ethanol}

Supply extender:

Initially, ethanol was promoted as a supply extender in an effort to reduce dependence on foreign oil. When it was first introduced on a commercial basis, ethanol was blended at the retail site, with retailers mixing 1000 gallons of ethanol with 9000 gallons of unleaded gasoline in their underground storage tanks. As the ethanol market matured, fuel distributors or "jobbers" would blend the fuels at their bulk facilities, or directly in the ianker trucks, and deliver the blended product to the dealers. Up until the mid-eighties, some of the larger oil companies including Chevron and Texaco, also marketed ethanol blend fuels. The larger oil companies have dropped out of this market however, and it is now held primarily by "independent" oil companies and dealers.

Octane enhancement:

At the same time that ethanol was recognized as a volume extender, oil companies became interested in its use as an octane booster. Gasolines are rated on their Antiknock Index (AKI), which is a measure of a fuel's ability to resist engine knock. The AKI of a motor fuel is the average of the Motor Octa- -2 Number (MON) and the Research Octane Number (RON). Optimum engine performance and fuel economy is achieved when the AKI or octane rating of a fuel is equal to that required by the engine in which it is combusted. When the octane rating is below recommended levels, pre-ignition of the air-fuel mix can occur in the cylinder resulting in loss of power and possible engine damage.

In the past, octane enhancement of gasoline was achieved in part by the addition of tetraethyl lead. Federal reductions in the allowable lead content in gasoline as per EPA (rulemakings on lead content) required the petroleum industry to use other octane enhancing components besides lead. Oil refineries responded by increasing the octane number of gasoline through more severe refining, and through the addition of alcohols and ethers, primarily ethanol and methyl tertiary butyl ether (MTBE).

Ethanol has a pump octane level of 112.5 , and will boost pump octane by 2.5 to 3 octane numbers when blended at 10 percent. Other octane enhancers are petrochemical additives such as toluene, benzene and petroleum derived alcohols or ethers such as MTBE and TBA.

Fuel oxygenate:

Carbon monoxide is a highly toxic gas that is caused from incomplete combustion. The primary strategy used to reduce $\mathrm{CO}$ emissions is to chemically add oxygen to the fuel through the addition of oxygenates. By increasing the amount of oxyge. 1 in the fuel, a more complete combustion of the fuel is achieved, with carbon monoxide (CO) oxidized to carbon dioxide (CO2). Fuel oxygenates include alcohols such as ethanol and methanol, and ethers such as methyl tertiary butyl ether (MTBE) and ethyl tertiary butyl ether (ETBE).

Ethanol can be used as an oxygenate in two ways, either as a direct blend or as a component for manufacturing ethyl tertiary butyl ether (ETBE). In the former case, ethanol is typically splash blended and is no different than when used as an extender. Ethanol blends have been used successfully to improve air quality by communities in Nevada, Colorado, Arizona and New Mexico. 
A disadvantage of using splash blended ethanol as an oxy'genate is that it increases the Reid Vapor Pressure (Rvp) of the finished fasoline. This can be particularly troublesome during the summer months as higher Rvp fuel increases hydrocarbon evaporative emissions, a precursor to ozone. While his problem could be overcome by either increasing the allowable ethanol concentration to 22 percent, or by limiting its use to winter months, the long range industry direction is anticipated to be the manufacture of ETBE.

Unlike ethanol, ETBE is pipeline fungible and consequently more acceptable to the oil industry. ETBE also has similar physical properties to MTBE, a compound currently used by industry for octane enhancement and enlcanment, and could use the same basic technology and facilities for production. Finally, ETBE, like MTBE, can reduce the aromatic content of gasoline. Aromatics such as benzene, toulene and xylene are extremely toxic compounds and are of increasing concern to air quality regulators.

The level of $\mathrm{CO}$ reduction varies depending on the oxygenate and the vehicle. A 10 percent ethanol blend contains 3.7 percent oxygen by weight, MTBE contains 2.7 percent oxygen, and ETBE contains 2.0 percent oxygen by weight. Theoretically, the higher the oxygen crntent of the fuel, the greater the reductions in $\mathrm{CO}$. However, older vehicles may experience greater $\mathrm{CO}$ reductions than vehicles equipped with oxygen sensors. In general, the addition of fuel oxygenates have been reported to reduce $\mathrm{CO}$ emissions by 10 to 30 percent depending on vehicle type.

\section{Fuel Ethanol Production and Consumption}

In 1979 , U.S. ethanol production was next to zero. With the aid of federal and state incentives the ethanol fuel industry expanded rapidly and was producing mure than 750 million gallons of ethanol fuel by the mid eighties (see Figure 4). The growth of this industry suffered a severe setback during 1986, however, when world oil prices plummeted. In November, 1985 a barrel of crude oil sold for approximately $\$ 30$. Seven months later, a barrel of crude oil had a market value of only $\$ 10$.

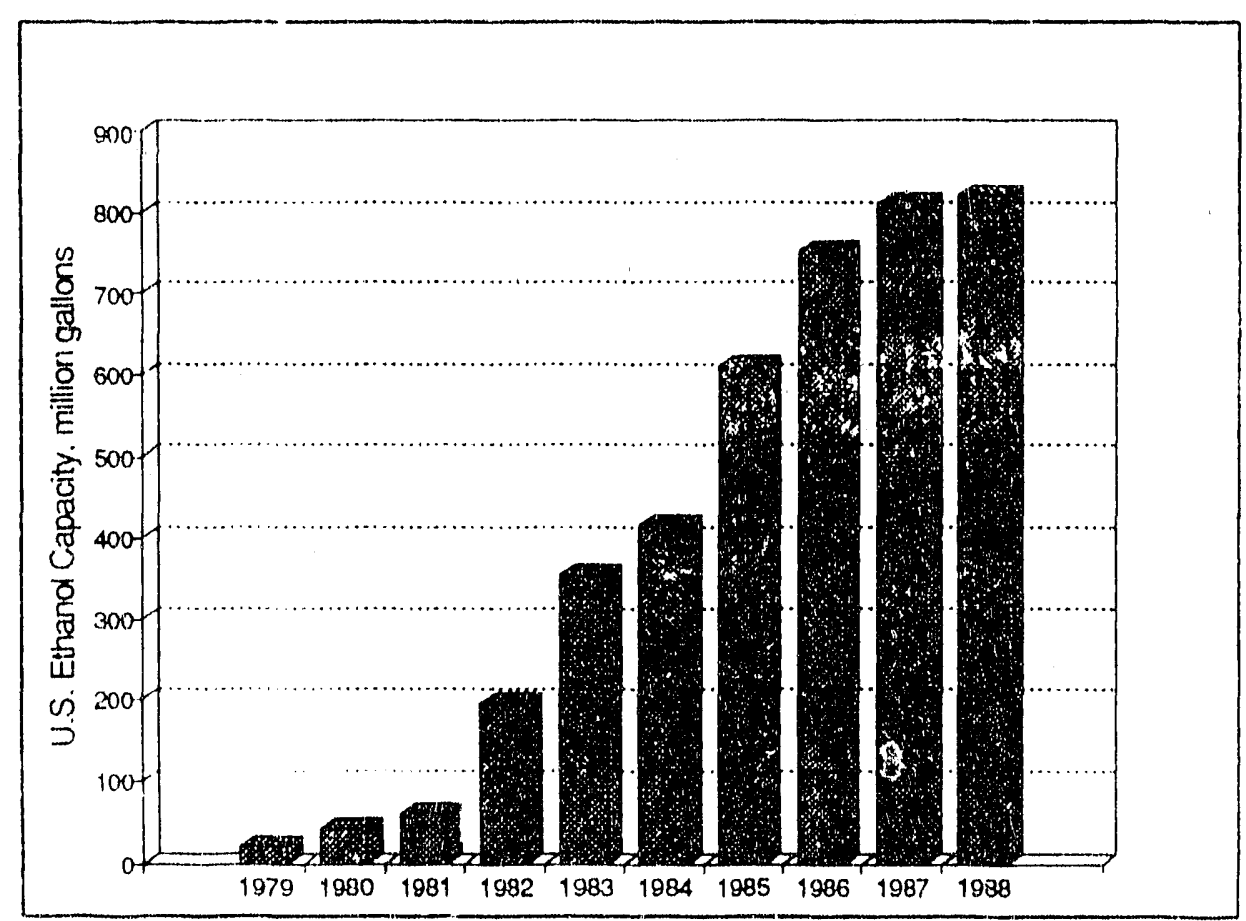

Figure 4. Historical growth of United States ethanol fuel production capacity from 1979-1988. (DOE, 1989) 
The decline in world oil prices directly impacted the value of ethanol. Wholesale gasoline, which helps to set the market value of an ethanol blend fuel, dropped in price by 50 percent. Similarly, petroleum based octane additives also became more competitive, further squeezing ethanol's market base. The result of these price drops was that fuel ethanol prices fell from a $\$ 1.60$ per gallon in January 1986, to only $\$ 0.73$ per gallon by December 1986 (GAO,1987). This decline severely eroded the profitability of ethanol producers and forced plant closures and expansion cutbacks.

With the recovery of the world oil market, ethanol prices have slowly edged up. As of September 1990 , the market price for ethanol was listed at $\$ 1.40$ per gallon. Industrial expansion also shows some signs of recovery, as approximately 16 million gallons of new ethanol capacity was brought on line in 1988 and an additional 11 million gallons are under construction. This brings the total nameplate capacity of the ethanol industry to somewhere around 1.35 billion gallons, with U.S. production reaching 850 million gallons in 1989. The extension of the federal fuel tax credits is also expected to improve the outlook for ethanol capacity expansions in the near future.

Washington State has undergone a similar growth in ethanol use. In 1979, 194,000 gallons of ethanol fuel were consumed in Washington State. By 1989, nearly 6.5 million gallons of ethanol, or 65 million gallons of ethanol blended fuel, were consumed by Washington motorists, see Figure S (Washington State Department of Licensing, 1990). Unlike the national ethanol market which saw a leveling off of growth in 1986, ethanol use in Washington doubled between 1986 and 1987 and did not level off until 1988.

Regionally, there are four operating ethanol production facilities which have a combined production capacity of $8,200,000$ gallons. The oldest plant is operated by Georgia Pacific and is located in Bellingham, Washington. This facility was constructed during World War II and recovers sugars from its pulping operation for use as an alcohol feedstock. The plant has a production capacity of 3 million gallons of ethanol per year and is operating at full capacity. A second, smaller ethanol plant is also located in Washington and is operated by the Pabst Brewing Company. The plant is located in Olympia and has an installed capacity of 700,000 gallon per year. The facility came on line in the early eighties and was built primarily to recover brewery wastes which were overloading the municipal wastewater treatment plant.

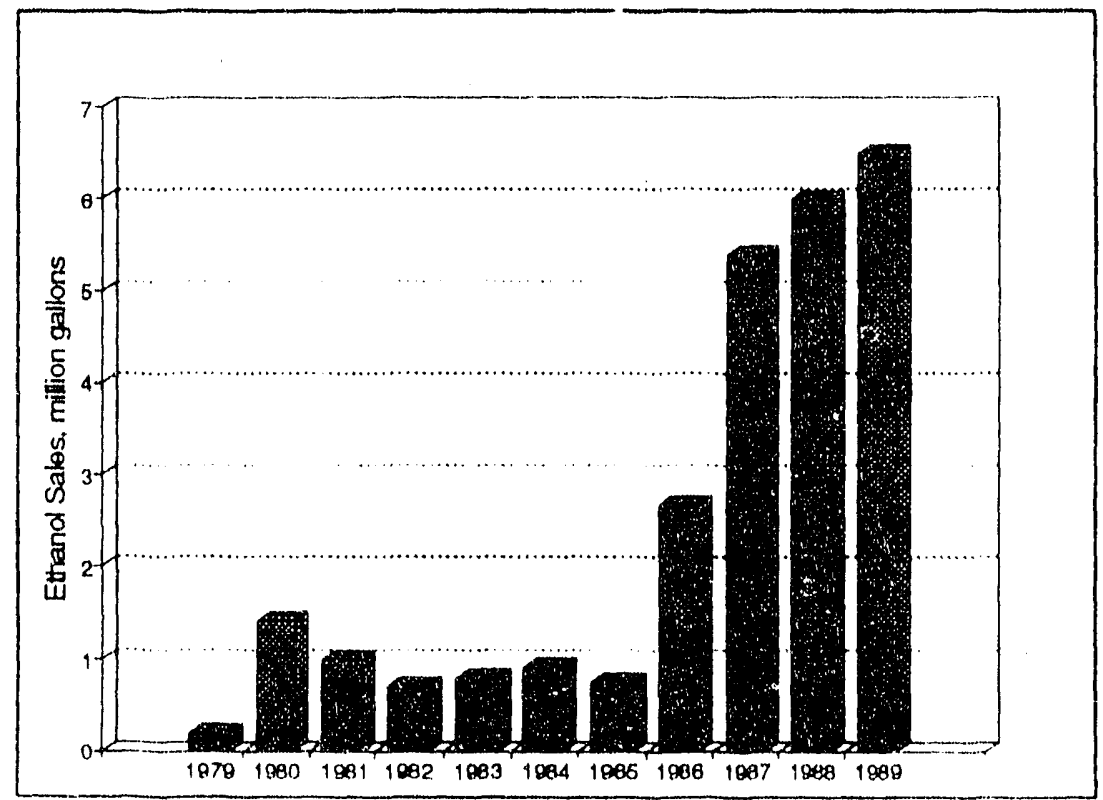

Figure 5. Historical use of ethanol fuel in Washington from 1979-1988. (Department of Licensing, 199()) 
The two other regional ethanol plants are located in Idaho and Montana. J.R. Simplot, a major agricultural company, operates a 3 million gallon plant in Caldwell, Idaho, using potato processing wastes as teedstock. A fourth ethanol plant is located in Ringling, Montana and is owned and operated by Alcotech. This plant has a production capacity of 1.5 million gallons and relies on distressed grain for a feedstock.

Washington State Ethanol Markets

\section{Existing markets}

Ethanol is marketed in Washington, and the region, as a volume extender/octane enhancer for gasoline. In this market, ethanol's value is determined by the wholesale price for gasoline plus state and federal tax credits. As the price of crude oil increases, the value of ethanol as a fuel extender also increases. Conversely, as crude oil prices decrease, so does the price paid for ethanol. Since 1988 the price of crude oil has been increasingly steadily and has more than tripled in price from its 1986 low of $\$ 10$ per barrel. Figure 7 presents historical fuel prices for gasoline and the calculated value of ethanol fuel.

Independent oil companies control the regicnal marketing of ethanol blended fuel as all of the large oil companies discontinued its sale in the mid-eighties. The three primary companies responsible for distributing ethanol blended fuel in Washington are Time Oil Company of Seattle, Washington, Ethanol Marketing Inc., of Boise, Idaho and CENEX, a national agricultural co-op. Time Oil serves Western Washington dealers, providing ethanol fuel to approximately 50 retail stations composed primarily of Jackpot dealers. Georgia Pacific is Time's major supplier of ethanol, with supplementary stocks supplied by Minnesota Corn Products when needed. On average, Time sells approximately 300,000 gallons of ethanol per month, with annual sales of about 3.6 million gallons.

Ethanol Marketing Incorporated (EMI) and CENEX supply Eastern Washington dealers, serving about 60 outlets comprised primarily of CENEX and Circle-K Stores. EMI distributes approximately 100,000 to 120,000 gallons per month of ethanol to Eastern Washington dealers, while CENEX supplies a similar amount to their dealers. The J.R. Simplot facility in Caldwell, Idaho is EMI's primary supplier, with additional supply provided by Alcotech. CENEX is supplied by their plant in Valhalla, North Dakota which has a production capacity of 4.5 million gallons per year.

The demand for ethanol currently exceeds the region's production capacity. Combined Washington, Idaho and Montana consume more than 11 million gallons of ethanol per year, with Washington being the largest market followed by Idaho at 4.5 million gallons and Montana at 250,000 gallons. This level of consumption exceeds the region's production capacity by 3 million gallons, the balance being imported from outside the region.

\section{Future markets}

Future markets for ethanol fuel in Washington State could include expansion of its use as a supply extender/octane enhancer, and the emerging oxygenated fuel market.

Supply extender: Future ethanol markets in Washington State could include an expanded presence as a gasoline extender and octane enhancer. In 1988, motor gasoline sales in Washington exceeded 2.2 billion gallons (see Figure 6) (Anderson, 1990). Over the same time, blended ethanol sales reached slightly more than 59 million gallons (5.9 million gallons of ethanol), representing a market share of less than 3 percent of total gasoline sales. By comparison, ethanol blended gasoline accounts for slightly more than 7 percent of the total U.S. gasoline consumption (DOE, 1989). 


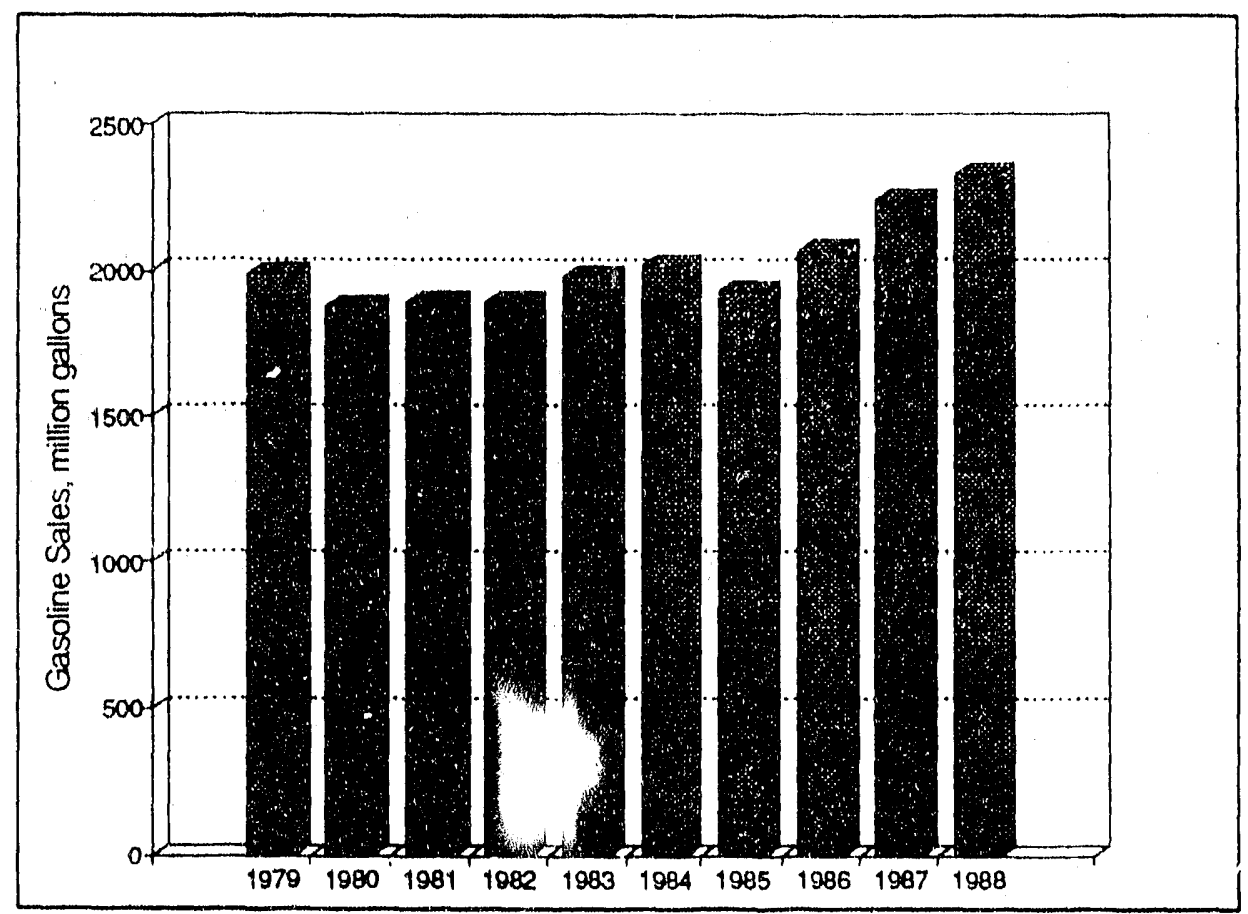

Figure 6. Historical motor vehicle gasoline use in Washington from 1977-1988. (Anderson, 1990)

Other states, most notably those located in the corn rich Midwest, have achieved much higher ethanol penetration rates than Washington. For example, in 1988, ethanol blend sales in Nebraska exceeded 34 percent of total gasoline sales. During the same period, ethanol blends achieved a market share of 29 percent of total gasoline sales in lowa, followed by penetration rates of 25 percent in Tennessee, 22 percent in Kentucky and 21 percent in New Mexico (DOE, 1989).

The success of ethanol sales in these and other states does not appear to be solely the result of liberal state tax incentives. Nebraska's tax credit of approximately 3 cents per gallon of ethanol blend is slightly below Washington's, while lowa's credit of one cent per gallon is less than one-third of Washington's incentive. Availability of feedstocks and public support are probably most responsible for the success of ethanol sales in these states. Other factors may include aggressive marketing, education, and promotion by private and public entities and the willingness of gasoline retailers to carry the product.

Increasing the demand for ethanol blend fuels in Washington should not present a problem. In fact, the major Washington distributors of ethanol blends have indicated plans to expand their market share and have found the existing environment of high gasoline prices complimenting their efforts. (jiven an ethanol blend markel share of only 7 percent of total State gasoline use, the national average, would increase the State consumption of ethanol to over 15 million gallons per year. Under a more aggressive scenario of 2.5 percent of the total state gasoline use, more than 53 million gallons of fuel cthanol could be consumed in Washington each year. With any market development scheme, the affect of subsidies on the State Highway Trust Fund would need to be examined. 
Oxygenate market: An emerging market for ethanol is as a fuel oxygenate. Recent amendments to the federal Clean Air Act have strengthened emission standards for carbon monoxide and established a fuel oxygen content level of 2.7 percent for 44 cities. These provisions will require the use of oxygen containing additives like ethanol and MTBE and could encourage the use of oxygenated fuels in other, unlisted areas.

How the petroleum industry responds to the "oxygen" mandate passed by Congress is difficult to forecast. The status quo favors MTBE as it is already being used by some refineries and it is a petroleum based product. ETBE, while not currently being produced, may also find support within the petroleum industry. With the extension of the federal alcohol fuel credit to ETBE production, some industry analysts feel that ETBE may have an economic edge over MTBE, particularly for refineries located in the Midwest. Since there is little investment if any required to switch from MTBE to ETBE, operational changeovers to ETBE could occur quickly if the economics were favorable.

Regardless of market share, fuel oxygenates have an increasing role to play in the production of motor fuels. During 1988, oxygenated fuels were added to approximately 21 percent of the nation's gas supply. MTBE's share amounted to about 14 percent of the country's gasoline use, an amount equivalent to about 380 million gallons of methanol, while ethanol accounted for about 7 percent. Although the ethanol industry's market sharc has remained the same, MTBE's share is improving with 1988 seeing a 24 percent increase in MTBE use over the previous year (DOE, 1989).

Locally, an increased use of fuel oxygenates by Washington refineries is also anticipated. Although no Washington cities were included in the EPA list of 44 cities, CO is a problem in some Washington airsheds. The Washington State Department of Ecology has identified the following seven cities as CO non-attainment areas - Seattle, Bellevue, Tacoma, Everett, Vancouver, Spokane and Yakima - and will probably recommend or perhaps even require the use of oxygenates in these areas.

Currently, the greater Puget Sound area is served almost exclusively by Washington insed refineries which delivered over 33 million barrels of gasoline to Puget Sound customers in 1987. In order to keep this market, local refineries would undoubtably respond to any air quality initiatives by producing a reformulated gasoline. Currently, it would appear that local refineries wouid favor MTBE. However, with the extension of the federal blenders credit, ETBE may enjoy a price advantage over MTBE. If this situation were to occur, as much as 64 million gallons of ethanol could be consumed on an annual basis in order to meet Western Washington refinery demands.

Summary: Growth in the ethanol fuel market looks promising. The extension of the federal fuel tax exemption largely eliminates investor uncertainty and provides a stable price base for producers of ethanol fuel. Rising oil prices have also boosted the demand for ethanol as well as its value. Finally, growth in the use of oxycenated fuels as a clean air strategy has opened a whole new market for ethanol. When taken together, these factors present a favorable market picture for ethanol sales in Washington State. While, the degree to which ethanol sales could penetrate Washington's motor fuel market is unknown, the market potential is large and should be able to support some level of regional increase in ethanol production. 


\section{Ethanol Prices}

Federal Incentives

Starting in 1978, the federal government has provided a number of incentives to promote the development of a domestic ethanol fuel industry. Tax incentives, loan programs, subsidized feedstocks and impcrt restrictions have all been applied by the federal government and ' largely define what the ethanal fuel industry is today. Following is a list of the most influential government programs to date.

- The Energy Tax Act of 1978 partially exempts fuels containing 10 percent ethanol from the federal gasoline excise tax. The Act also established a 10 percent energy investment tax credit on equipment purchased to produce ethanol.

- The Crude Oil Windfall Profit Tax of 1980 extended the investment tax credits and the excise tax exemption through 1985 and 1992, respectively. A blenders income tax credit was also created by this law.

- The Omnibus Reconciliation Act of 1980 placed import duties on fuel ethanol thereby removing any tax advantages to ethanol importers.

- The Energy Security Act of 1980 authorized funding to build ethanol plants.

- The 1980 amendment to the Consolidated Farm and Rural Development Act authorized the Farmers Home Administration to guarantee loans for alcohol production facilities.

- The Surplus Agricultural Commodities Disposal Act of 1982 provided the authority to use surplus Commodity Credit Corporation (CCC) grain stocks as a feedstock for ethanol.

- The Food Security Act of 1985 authorized the Secretary of Agriculture to make federally owned commodities available free, or at a reduced cost, for the production of liquid fuels.

- The Miscellaneous Tax and Budget Reconciliation Act of 1990 extended the excise tax exemption for gasoline blended with 10 percent ethanol through December 31,2000 . The blenders tax credit was also extended through December 31, 2000.

\section{Gasoline Excise Tax Exemption:}

The most influential federal ethanol incentive is the gasoline tax exemption. This incentive was passed in 1978 and exempts gasoline from a portion of the federal excise tax if it is blended with at least 10 percent ethanol. The availability of this subsidy allowed ethanol producers to compete with gasoline as well as attract investors.

Initially, a 10 percent ethanol blend gasoline was exempt from 4 cents of the 9 cent per gallon federal gasoline excise tax. This is equivalent to a 40 cent per gallon subsidy for each gallon of ethanol produced. Passage of the Surface Transportation Assistance Act of 1982 increased the subsidy to 5 cents per gallon of blended gasoline, while the Tax Return Act of 1984 raised the subsidy again to 6 cents per gallon. 
No further action was taken by the federal government until passage of The Miscellaneous Tax and Budget Concilation Act of 1990. Although this Act reduced the excise tax exemption to 5.4 cents per gallon, its passage was critical to the future of the ethanol industry. By extending the ethanol tax exemption from 1992 through the year 2000, the federal government renewed its commitment to the development of an ethanol fuels industry. The Act also established a 10 cent per gallon tax credit on the first 15 million gallons per year of ethanol produced at facilities with a capacity less than 30 million gallons per year. These actions by the federal government should spur further investment in the industry and will strengthen ethanol's position within the motor fuels market.

\section{Blenders Credit:}

A blenders income tax credit was introduced in 1980 as part of the Crude Oil Windfall Profit Tax. This credit may be claimed by a blencier of ethanol/gasoline and was originally set at 40 cents per gallon of ethanol to parallel the federal fuel excise tax exemption. The credit increased to 50 cents per gallon in 1982 and was raised to 60 cents per gallon in 1984. The Miscellaneous Tax Act of 1990 set its current value of 54 cents per gallon and extended it through the year 2000 .

The blender tax credit cannot be taken in addition to the excise tax exemption. To date, few blenders take the credit over the exemption because the credit is treated as income and taxed accordingly, reducing its value to the blender by approximately one-third that of the excise tax exemption. Use of the blender tax credit may increase, howeve:, as the Treasury Department extended the blenders credit to Ethyl Tertiary Butyl Ether (ETBE) in 1990. Currently, ETBE is not eligible for the excise tax exemption because gasoline containing ETBE would contain less than 10 percent ethanol.

\section{State Subsidies}

State incentives have also played an important part in the development of the ethanol fuel industry. Twenty seven states offer incentives to ethanol producers/blenders ranging from state motor fuel tax exemptions to property tax savings.

In Washington, four separate incentives are available to ethanol producers. The primary incentive is the state fuel tax credit as defined under RCW 82.63.225. Under this statute, alcohol that is sold for use as a motor fuel is exempt from the state fuel tax. The current fuel tax stands at \$.22 per gallon of gasoline, increasing to $\$ .23$ per gallon on April 1, 1991. In addition to the state fuel tax exemption, a credit equal to 60 percent of the fuel tax is allowed for every gallon of alcohol used in a fuel blend containing at least $91 / 2$ percent alcohol by volume. When combined, the state fuel tax exemption of $\$ .22$ per gallon of ethanol coupled with the 60 percent fuel tax credit, yield a state ethanol fuel subsidy of $\$ 0.352$ per gallon.

Other state ethanol incentives include a property tax exemption for the six years following the date on which an ethanol producing facility becomes operational (RCW 84.36.490), a retail sales tax exemption (RCW 82.08.0286) and an exemption from the state use tax (82.12.0281). All state incentives are scheduled to expire on December 31, 1992.

\section{Ethanol's Market Value}

As discussed, the ethanol fuel industry is heavily subsidized and at present could not exist without Government support. Therefore, these credits are integral to the value of ethanol. In Washington State, federal and state tax credits combine to form a subsidy of approximately 9 cents per gallon of a 10 percent ethanol/gas blend. This is equivalent to $\$ 0.90$ per gallon of ethanol. 
While government subsidies help set the value of ethanol to the producer, the rack, or wholesale price of gasoline sets the market price for ethanol blend fuels. Unless it can be marketed as a premium fuel, the pump price for a 10 percent ethanol blend should equal the price of regular unleaded. Therefore, a distributor of ethanol blends has to sell his fuel at a price equal to or below the wholesale price a dealer would pay for regular unleaded. Since a dealer would be indifferent to an ethanol blend if it is sold at the sume price as gasoline, a distributor will typically sell the fuel at a cost 1 or 2 cents below wholesale gatsoline prices.

The historical relationship between wholesale gasoline prices and ethanol selling prices is shown in Figure 7. The ethanol prices are FOB Decatur, IL. (Information Revenues). The wholesale gasoline prices are national average figures (Energy Information Administration). The calculated ethanol price curve is the sum of the wholesale gasoline price and the federal and state incentives, less an assumed marketing cost of $\$ 0.22 /$ gallon. The calculated price is very close to the actual selling price beginning in about 1985. Before that time ethanol sold for a premium sometimes even above the indifference price. For predictive purposes, the ethanol selling price in Washington is assumed to follow the relationship between wholesale gasoline prices and incentives.

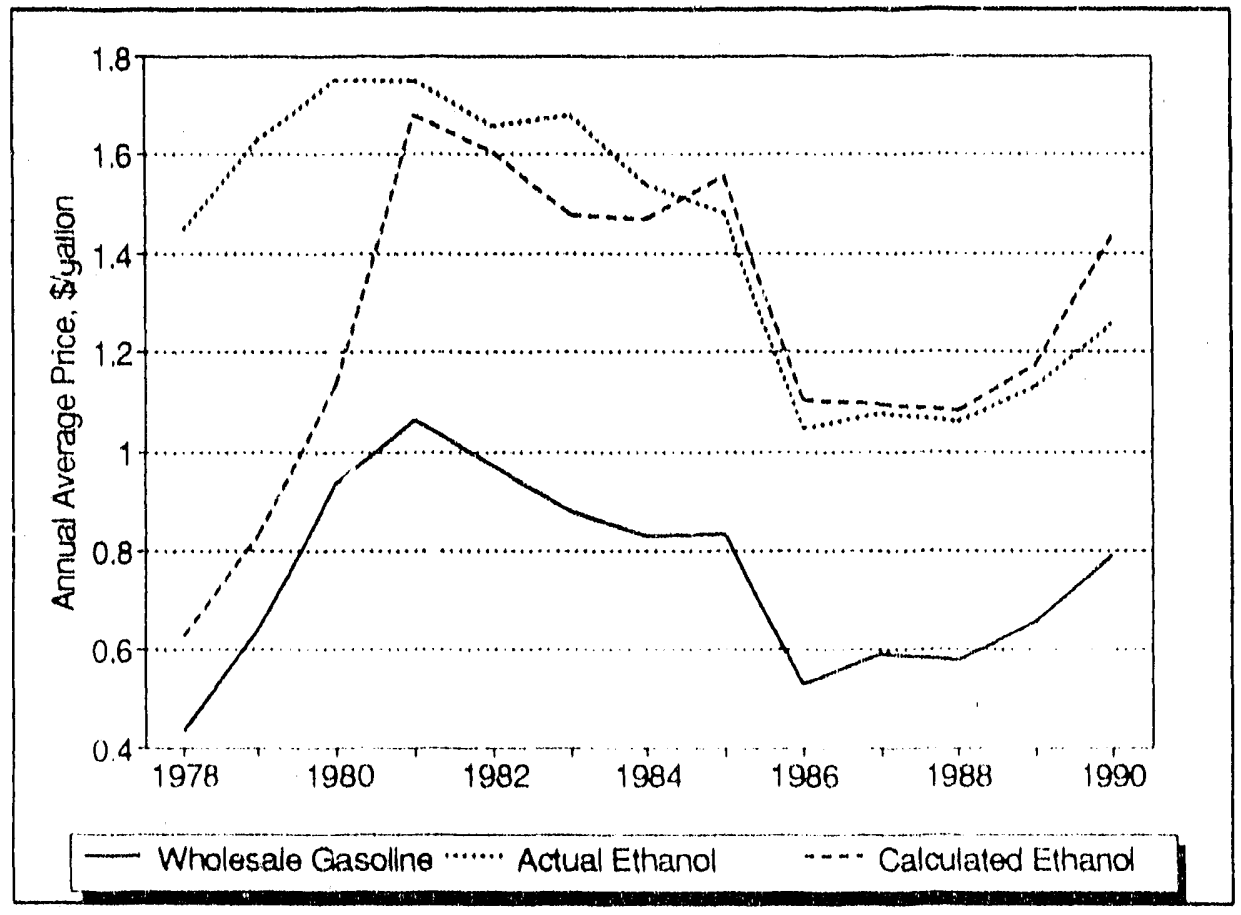

Figure 7. Historical relationship between wholesale gasoline prices, ethanol fuel selling price, and calculated ethanol selling price based on incentives. 


\section{Economics of Ethanol Production from Paper}

The economics of producing any product in the private sector is a question of profitability. Will the sale of the product bring in enough revenue to cover the cost of production and provide a reasonable return on the capital dollars invested? The elements involved in an economic analysis include the following: capital costs, cost of capital, operating and maintenance costs, financing options, federal or state incentives, and revenue from the sale of products and by-products.

The information available on the cost of producing ethanol from waste paper comes from the technical literature. This literature is based on proposed facilities using technologies that in some cases have not been demonstrated at a commercial scale. Three studies provided enough data to make a reasonable evaluation of the overall costs. These studies are the Tennessee Valley Authority dilute acid hydrolysis, the Gulf and University of Arkansas enzymatic process, and the Solar Energy Research Institute enzymatic process.

\section{Tennessee Valley Authority Dilute Acid Hydrolysis}

TVA published a report evaluating the economics of converting 500 tpd of waste-derived feedstock (WDF) to 5.2 million gallons of ethanol fuel per year and other chemicals using a dilute acid process (Barrier, 1990). The WDF would be recovered from mixed solid waste at a separate facility and delivered to the ethanol facility.

The process involves feeding the WDF to a hydrolysis reactor where dilute sulfuric acid $(2 \%)$ is added. The system is heated to $160^{\circ} \mathrm{C}$ by injecting steam. Under these conditions, cellulose is converted to glucose and hemicellulose is converted to xylose and a small amount of furfural. The mixture is de-watered and the remaining solids fed to the boiler to produce steam. The liquid is fed to a stripper that removes the furfural and then to a tank where lime neutralizes the sulfuric acid. The remaining liquid is fermented to ethanol, concentrated by distillation, and sold as a fuel.

One ton of WDF is estimated to give 30 gallons of ethanol and 32 pounds of furfural. The total energy requirements are estimated at $2.5 \mathrm{MBtu} /$ ton of WDF. The energy available in the residues that would be burned in the boiler are $13 \mathrm{MBtu} / \mathrm{ton}$. The plant should be able to supply all its process energy needs plus sell excess electricity as a by-product.

The capital costs for the 500 tpd processing system were estimated on the basis of vendor quotes for the major equipment. Equipment installation, instrumentation, piping, etc. were estimated using standard cost factors. Table 5 shows the elements of the capital cost estimate. These costs are equivalent to $\$ 8.70 /$ gallon annual capacity or $\$ 275.50 /$ ton WDF annual capacity.

The cost of production includes chemical costs, utility costs, supplies, tixed charges such as depreciation, insurance, local taxes, and maintenance. Table 6 shows the values used in the TVA study.

Table 5

\section{Capital Costs for 500 tpd WDF to Ethanol Facility}

Item

Direct Costs

Indirect Costs

Fees \& Contingency

Total Fixed Capital

Working Capital

Total Capital Investment
Cost, million \$

28.0
5.4
4.7
38.1
7.3
45.5


Table 6

\section{Production Costs for TVA Dilute Acid}

Hydrolysis of WDF

\begin{tabular}{lrr} 
Element & \multicolumn{1}{c}{$\$ \mathbf{y r}$} & c/gallon \\
\hline Raw Materials & & \\
Feedstock & $-4,950,000$ & -0.95 \\
Acid and lime & 679,538 & 0.13 \\
Yeast, etc. & 397,104 & 0.08 \\
Denaturant & 124,265 & 0.02 \\
Water \& Disposal & 180,299 & 0.03 \\
Labor & $1,686,923$ & 0.32 \\
Supplies & 228,890 & 0.04 \\
Fixed Charges & & \\
Depreciation (20 yrs) & $1,873,657$ & 0.36 \\
Insurance \& local tax & 762,966 & 0.15 \\
Maintenance & $1,525,933$ & 0.29 \\
Plant Overhead & 843,462 & 0.16 \\
& & 0.64
\end{tabular}

TVA assurced four sources of revenue. They include ethanol fuel, carbon dioxide, furfural and electricity. The quantity, price and net income are shown below:

\begin{tabular}{lrrr} 
Product & Quantity & \$/unit & \$/year \\
\hline Ethanol(gal) & & & \\
Carbon Dioxide (t) & $5,219,145$ & 1.25 & $6,523,931$ \\
Furfural (t) & 15,917 & 10.00 & 159,166 \\
Electricity (kWh) & 2,641 & $1,000.00$ & $2,640,825$ \\
Total revenue & $70,700,000$ & 0.04 & $2,826,349$ \\
& & & $\$ \mathbf{1 2 , 1 5 0 , 2 7 1}$
\end{tabular}

The base case for TVA results in a 19.35 percent return on investment (ROI) before taxes. The ROI sensitivity to tipping fee, electricity selling price, and plant size were calculated. TVA's assumption of a tipping fee for an already processed waste derived fuel is very optimistic. The WDF has some value as fuel and it is doubtful that someone would pay to process raw MSW into a WDF and then pay to dispose of the processed material. 


\section{Gulf Oil/University Arkansas Enzymatic Process}

In 1980, Gulf Oil Chemicals reported on the cost of converting a mixture of pulp mill waste and municipal solid waste into ethanol fuel using enzymatic hydrolysis. Their costs were based on results from a 1 tpd pilot plant. Costs have been converted to 1990 dollars. Table 7 shows the estimated capital costs for a 2,000 tpd facility. The largest capital cost item is for general facilities and includes boilers and water treatment equipment. Table 8 shows the projected production costs. 'The feedstock was assumed to cost $\$ 14 /$ ton.

Their process was based on processing 2,000 tpd of cellulosic waste material, containing approximately 57 percent cellulose, into 50 million gallons per year of ethanol fuel and a byproduct animal feed. A typical mixed feedstock would contain $2 / 3$ processed municipal solid waste and $1 / 3$ pulp mill waste. About 15 percent of the feedstock would be used to produce the cellulase enzymes. The remaining material would be pasteurized and combined with the cellulase broth and processed by simultaneous saccharification and fermentation (SSF). The beer slurry (approximately 3.5 percent ethanol content) from the SSF process is neutralized prior to distillation. The residues from the alcohol recovery section are evaporated to produce a 60 percent solid content syrup animal feed by-product. The lignin and unconverted cellulose would be used to provide essentially all the thermal energy and a major part of the turbine drive energy.

The yield is expected to be 71 gallons ethanol per ton of feedstock, substantially higher than the TVA dilute acid process. The system is also expected to be 48 percent energy efficier.t based on the energy content of the products and feedstocks.

Table 7

Estimated Capital Costs for 2,000 ton per day Gulf Enzymatic Ethanol Facility

Riceiving \& Storage

10.7

Materials Preparation

Enzyme Production

10.0

SSF

20.2

Distillation

12.5

Condensate Treatment $\quad 16.8$

General Facilities

32.9

Total Installation

117.1

Contingency, $15 \%$

17.6

Total Investment

134.7 
Table 8

\section{Production Cost \\ Gulf Enzyme Process}

\begin{tabular}{lcr} 
Item & million $\$ / \mathbf{y r}$ & c/gal \\
\hline Feedstock & 9.24 & 18.5 \\
Nutrients,Chemicals,etc. & 11.6 & 23.2 \\
& 10.6 & 21.2 \\
Utilities & 3.0 & 6.0 \\
Labor & & \\
Fixed Charges & 13.4 & 26.8 \\
Depreciation (10yr) & 2.7 & 5.4 \\
Insurance \& local tax & 5.4 & 10.8 \\
Maintenance & 55.9 & 11.9 \\
Total Production Cost & &
\end{tabular}

Gulf assumed two income streams. One from the sale of ethanol and the other from the sale of animal feed. They calculated that the animal feed would provide an income equal to $\$ 0.42 /$ gallon of ethanol sold. Assuming 100 percent equity financing and a 10 year amortization period for capital recovery, the necessary selling price for the ethanol to give a 15 percent after-tax ROI was $\$ 1.44 /$ gallon. Gulf also examined the sensitivity to size of the facility and to the financing. As expected the smaller plants resulted in a higher selling price required to meet the 15 percent ROI criteric. For a 10 million gallon plant the sellin price would have to be $\$ 2.50 /$ gallon and for a 25 million gallon facility the price would $b_{b}$ $\$ 1.75 / g a l l o n$. The effect of financing was shown when they considered financing 80 percent of the capital cost with municipal bond financing. The required ethanol selling price dropped from $\$ 1.44$ to $\$ 0.95 /$ gallon. Obviously, the leveraging of funds would result in a higher ROI.

\section{SERI Ethanol from Paper}

The Solar Energy Research Institute recently released a draft report on the cost of producing ethanol fuel from waste paper (SERI, 1990). The report makes use of the model SERI developed to estimate the cost of producing ethanol fuels from wood feedstocks (Hinman,1990). Several laboratory measurements on ethanol yields from paper feedstocks were used to calculate production costs using their model.

The SERI process is very similar to that proposed by Gulf in 1980. The paper is pulped and sterilized and then transferred to the SSF processing area. Cellulase enzymes are produced from a portion of the paper feedstock. Enzymes, nutrients, and yeast are added and the resulting ethanol is sent to distillation. The insolubles and organics are dried and sent to the boiler as fuel.

Ethanol ;ields are based on 65 gallons per dry ton of paper or 63 gallons per ton of paper as received. The energy balance details for the paper to ethanol facility were not published. Howeve:, for the wood to ethanol facility the steam requirements are 33,000 Btu/gallon of ethanol and the electric requirements are $3.14 \mathrm{kWh} / \mathrm{gallon}$. The unfermentable material is sufficient to provide all the fuel needed to meet the steam needs as well as provide an excess of electricity that would be sold as a by-product. 
A detailed capital cost breakdown was not provided for the paper to ethanol facilities. However, the capital and operating costs were presented for conversion facilities of different sizes.

The operating costs for three different sized facilities are shown in Table 9. The raw material costs were independent of the size of the facility. They assumed $\$ 10.75 /$ ton would be paid for the paper delivered to the facility. The labor, overhead, and maintenance costs per gallon of ethanol were all influenced by the size of the facility. SERI assumed a 20 percent capital charge rate which takes account of federal income taxes, assumes a 15 year amortization of capital and a 10 percent after tax rate of return. A $\$ 0.05$ cent/gallon credit is assumed from the sale of excess electricity produced by the facility. As a point of reference, in Washington about 450,000 tons of mixed paper are generated each year, 250,000 tons in the Puget Sound area and about 65,000 tons are currently collected. A facility to handle all of the mixed paper generated would cost $\$ 66$ million, one to handle all of the Puget Sound area would cost $\$ 42$ million, and one to process the paper currently collected would cost $\$ 16$ million.

\section{Table 9}

Ethanol Production Costs Using SERI Process

\begin{tabular}{lrrr} 
Item & \multicolumn{3}{c}{ Facility Size } \\
\hline Tons MWP/year & 65,500 & 248,500 & 450,600 \\
& & $\ldots . . .-$ Cost cent/gallon-...... \\
Raw Material & 18.86 & 18.86 & 18.86 \\
Utilities & 1.41 & 1.41 & 1.41 \\
Labor & 9.77 & 6.82 & 5.89 \\
Maintenance & 46.48 & 32.43 & 28.02 \\
Annual Operating Cosi & 71.52 & 53.51 & 45.96 \\
Capital Charge & 81.86 & 57.11 & 49.36 \\
Required ethanol & & & \\
selling price & 160.00 & 111.00 & 99.00
\end{tabular}

\section{Comparison of Studies}

The major differences between the TVA study and the Gulf and SERI studies were the . technologies considered, the size of the facility, the capital cost, the feedstock cost, and the by-product credits. These differences, in general, are the factors most sensitive in determining the required selling price of ethanol fuel. Table 10 shows the values assumed by the different studies. 
Table 10

Comparison of Economic Studies

\begin{tabular}{|c|c|c|c|}
\hline Purameter & TVA & Gulf & SERI \\
\hline Feedstock & WDF & WDF\&mill & Paper \\
\hline Size, tpd & 500 & 2,000 & 2,000 \\
\hline Yield, gal/ton & 30 & 71 & 65 \\
\hline Technology & dilute acid & enzyme & enzyme \\
\hline Capital Cost, M\$ & 45.5 & 134.6 & 90.6 \\
\hline Capital Cost, \$/gal-yr & 8.72 & 2.68 & 2.24 \\
\hline O\&M Cost, $\$ / \mathrm{gal}$ & 1.07 & 0.61 & 0.34 \\
\hline Feedstock Cost, $\$ /$ ton & -30 & 14 & 10.75 \\
\hline Feedstock Cost, \$/gal & -0.95 & 0.185 & 0.166 \\
\hline Depreciation Period, yr & & 10 & 15 \\
\hline By-products & furfural, $\mathrm{CO} 2$ & animal & electricity \\
\hline $\begin{array}{l}\text { By-product Credits, \$/gal } \\
\text { ROI }\end{array}$ & $\begin{array}{c}\text { \& electricity } \\
1.08 \\
10 \mathrm{RT}\end{array}$ & $\begin{array}{l}\text { feed } \\
0.42\end{array}$ & 0.07 \\
\hline Selling Price for ROI, $\$ / \mathrm{gal}$ & 1.25 & 1.44 & 088 \\
\hline
\end{tabular}

Abbreviations:

$\mathrm{O} \& \mathrm{M}=$ operations and maintenance, no feedstock or capital costs

ROI = return on investment, all assumed $100 \%$ equity

$\mathrm{AT}=$ after federal taxes and $\mathrm{BT}=$ before federal taxes

$\mathrm{M} \$$ = million 1990 dollars

TVA considered acid hydrolysis at a relatively small facility. Both the technology and the small size result in a high capital cost for gallon of annual capacity. TVA shows a cost of $\$ 8.72$ per gallon of annual capacity, while Gulf and SERI showed a capital cost of $\$ 2.68$ and $\$ 2.24$ per gallon of annual capacity, respectively. Since return on investment is based on the capital cost, the TVA facility will have much higher fixed costs per gallon of production.

TVA also assumed that they would receive a tipping fee of $\$ 30 /$ ton for the waste-derived feedstock. Gulf and SERI assumed they would purchase feedstock at a cost of $\$ 14 /$ ton and $\$ 10.75 /$ ton, respectively. The yield of ethanol per ton of feedstock also showed substantial differences. TVA assumed 30 gallons per ton whereas Gulf assumed 71 gallons per ton and SERI assumed 65 gallons per ton. Thus the contribution of feedstock cost per gallon of ethanol ranged from $\$ 0.16 /$ gallon for the SERI process to a credit of $\$ 1.00$ per gallon for the TVA process.

By-products play an important role in determining the required selling price for ethanol fuel. TVA assumed income from the sale of furfural, carbon dioxide, and electricity in addition to the ethanol sales. The by-product credits were assumed to provide $\$ 1.08$ of income for each gallon of ethanol produced. This large by-product credit plus the tipping fee income counterbalance the large capital and operating costs for their proposed facility. Gulf and SERI also considered incomes from by-product sales. 
Gulf assumed that they would produce an animal feed from the material that was not converted into ethanol. SERI assumed that they would burn the non-fermentable material and provide process energy plus excess electricity that could be sold. This is a good illustration of having to decide what process options will be most economic. A plant can not easily produce both animal feed and energy. If animal feed is produced than fuel must be purchased to provide steam and the electricity must be purchased.

Gulf assumed that the animal feed could be sold for $\$ 120 /$ ton. This would give a by-product income equal to $\$ 0.42 /$ gallon of ethanol produced. The cost of purchasing steam and electricity was $\$ 0.21 /$ gallon of ethanol giving a net gain of $\$ 0.21 /$ gallon. SERI assumed the sale of electricity at $\$ 0.04 / \mathrm{kWh}$ would provide an income equal to $\$ 0.05 /$ gallon of ethanol plus there would be no need to purchase energy. A net gain of $\$ 0.28 /$ gallon of ethanol. The choice of which by-products to produce depenos on the markets for the by-products, their price, and the added capital and operating costs to produce the by-products.

Each study looked at the overall economics of the facility from a different viewpoint. TVA assumed a selling price for the ethanol and by-products, assumed 100 percent equity financing, and calculated a return on investment before taxes. Gulf computed the required selling price of ethanol to provide a 15 percent after tax return on investment. SERI calculated an operating cost after taking by-product credits and determined the required ethanol selling price to provide a 10 percent after-tax rate of return. 


\section{Economics of Ethanol Production from Mixed Waste Paper in Washington}

In the next few sections the expenses, revenues and return on investment will be examined in more detail for a hypothetical mixed waste paper to ethanol facility located in Washington. The major factors effecting expenses, revenues, and profitability will be examined by sensitivity analysis.

\section{Costs of Producing Ethanol from Paper in Washington}

The estimated cost of producing ethanol fuel from mixed waste paper in Washington used results of previously published studies (SERI,1990 and Emeret, 1980). These numbers however should only be used to consider the practicality of such a venture and the sensitivity of the project to major project variables. The actual costs of producing ethanol requires more in-depth and detailed examination.

The hypothetical facility considered for this exercise would use enzymatic hydrolysis and have a capacity to process 250,000 tons per year of mixed waste paper. The feedstock would be purchased at $\$ 15 /$ ton from both residential and commercial recycling programs. The facility would produce 17.5 million gallons of ethanol per year and sell electricity as a by-product. The Gulf and SERI studies were used to arrive at reasonable base case values tor capital and O\&M costs. The yields are based on samples of mixed waste paper collected in Olympia and analyzed by the Tennessee Valley Authority and Mycotech, Inc.

Given the base case assumptions presented in Table 11 , a selling price of $\$ 1.24$ per gallon is required for the ethanol plant to be profitable. The selling price is the price that must be received for each gallon of ethanol fuel to pay for fixed and variable costs plus provide a set return on investment, i.e. profit, after federal taxes. The assumed return on investment for the base case is twelve percent.

Table 11

\section{Base Case Assumptions for Hypothetical Ethanol Plant in Washington}

\section{Parameter Value}

Size, tpd

Capital Cost, \$/gal-yr

Capital Cost, $\mathrm{M} \$$

Yield, gallons/ton

Feedstock Cost, \$/ton

Feedstock Cost, \$/gal

O\&M Cost, \$/gallon

By-product credit, \$/gallon

Depreciation period, years

Debt fraction

ROIAT, percent

Tax credit, \$/gallon

Required selling price, \$/gal
758.00

3.00

52.50

70.00

15.00

0.21

0.45

0.05

15.00

0.00

12.00

0.07

1.24 
The percent contribution to the production cost from the various cost elements are shown in Figure 8. O\&M costs account for over 50 percent of the production costs with feedstock cost and depreciation each contributing about 25 percent. Changes to cost elements with high percentage contributions to the total cost have more effect than elements that are not as large, i.e. the element is more sensitive. There is a direct relationship between O\&M costs and cost of production, i.e. a ten cent per gallon increase in O\&M costs increases the production cost by ten cents. Feedstock costs and depreciation costs are not quite as straight forward.

Feedstock cost per gallon of ethanol produced is equal to the unit cost of feedstock divided by the ethanol yield. Thus an increase of one dollar per ton in feedstock cost increases the production cost by $\$ 0.014$ if the yield is 70 gallons/ton. Figure 9 shows the relationship between total production cost, feedstock cost, and yield.

Depreciation costs are calculated by dividing the capital cost per gallon of annual capacity by the rumber of years in which the capital would be recovered. This is called straight line depreciation. The base case assumes a capital cost of $\$ 3.00$ per gallon of annual capacity and a depreciation period of 15 years. The depreciation cost per gallon of ethanol is thus $\$ 0.20$ /gallon. Figure 10 shows the relationship between total production cost, capital cost and depreciation period. The production cost is very sensitive to the depreciation period, as the period gets shorter.

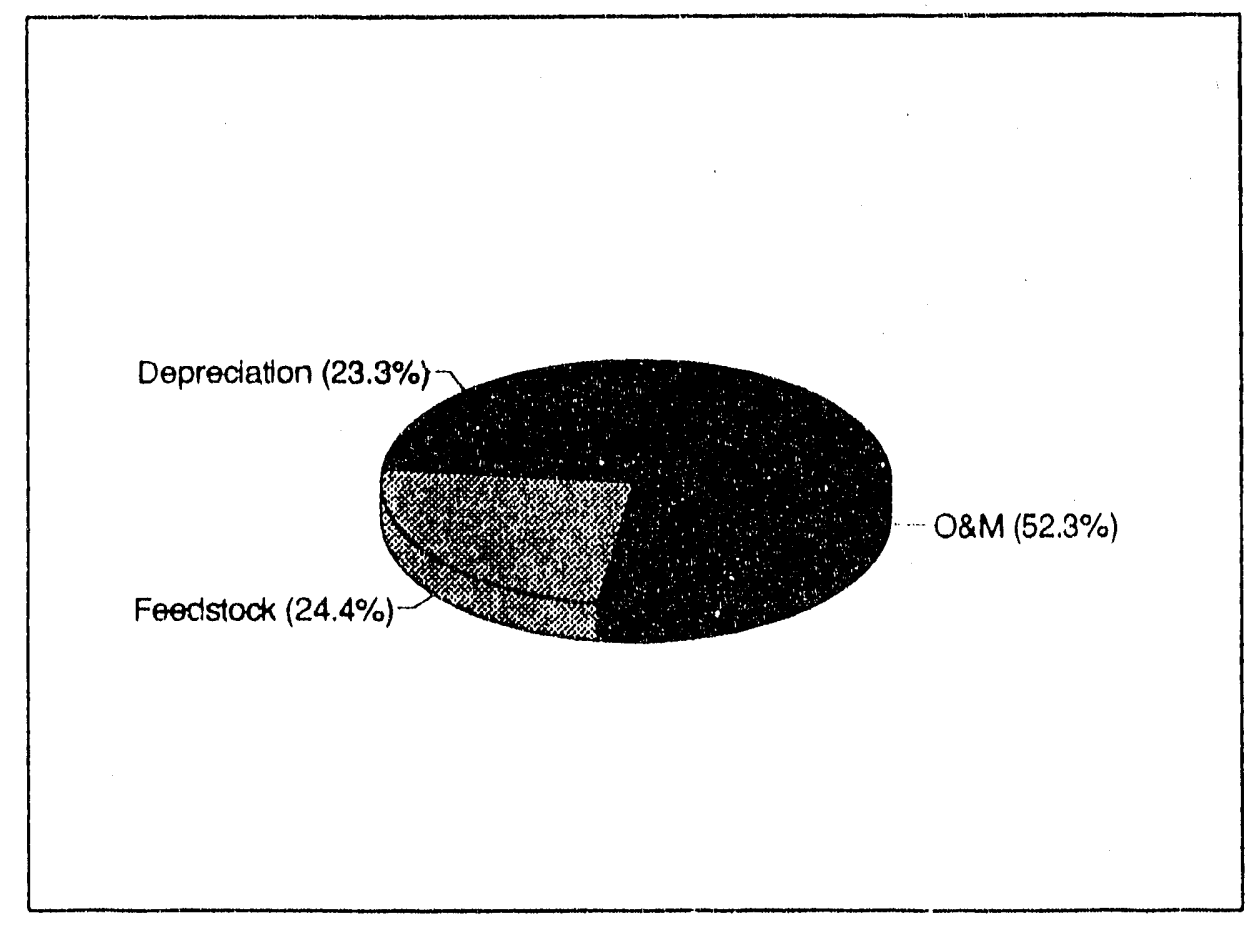

Figure 8. Percentage contribution of major operating costs in producing ethanol from paper. 


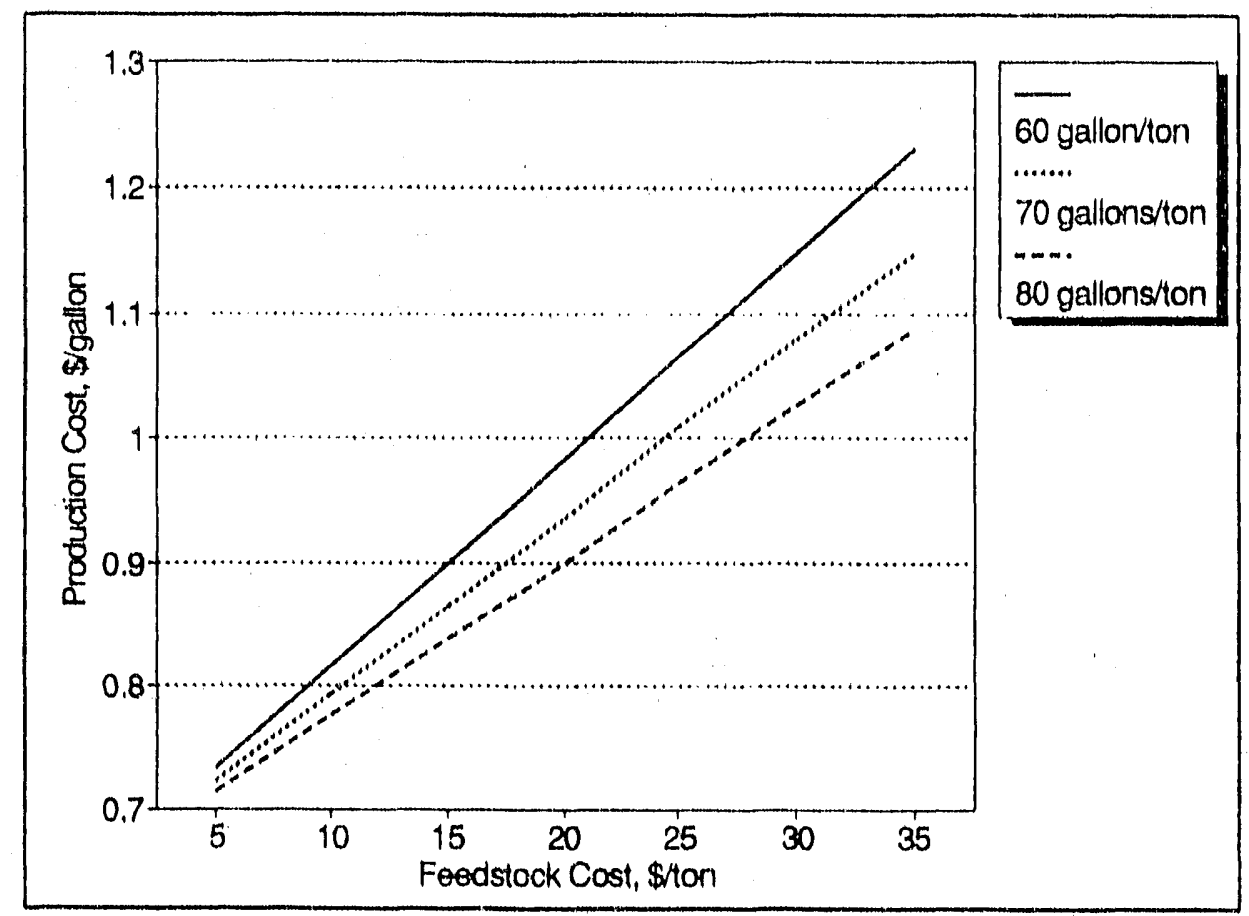

Figure 9. Sensitivity of ethanol production costs to feedstock costs and yields

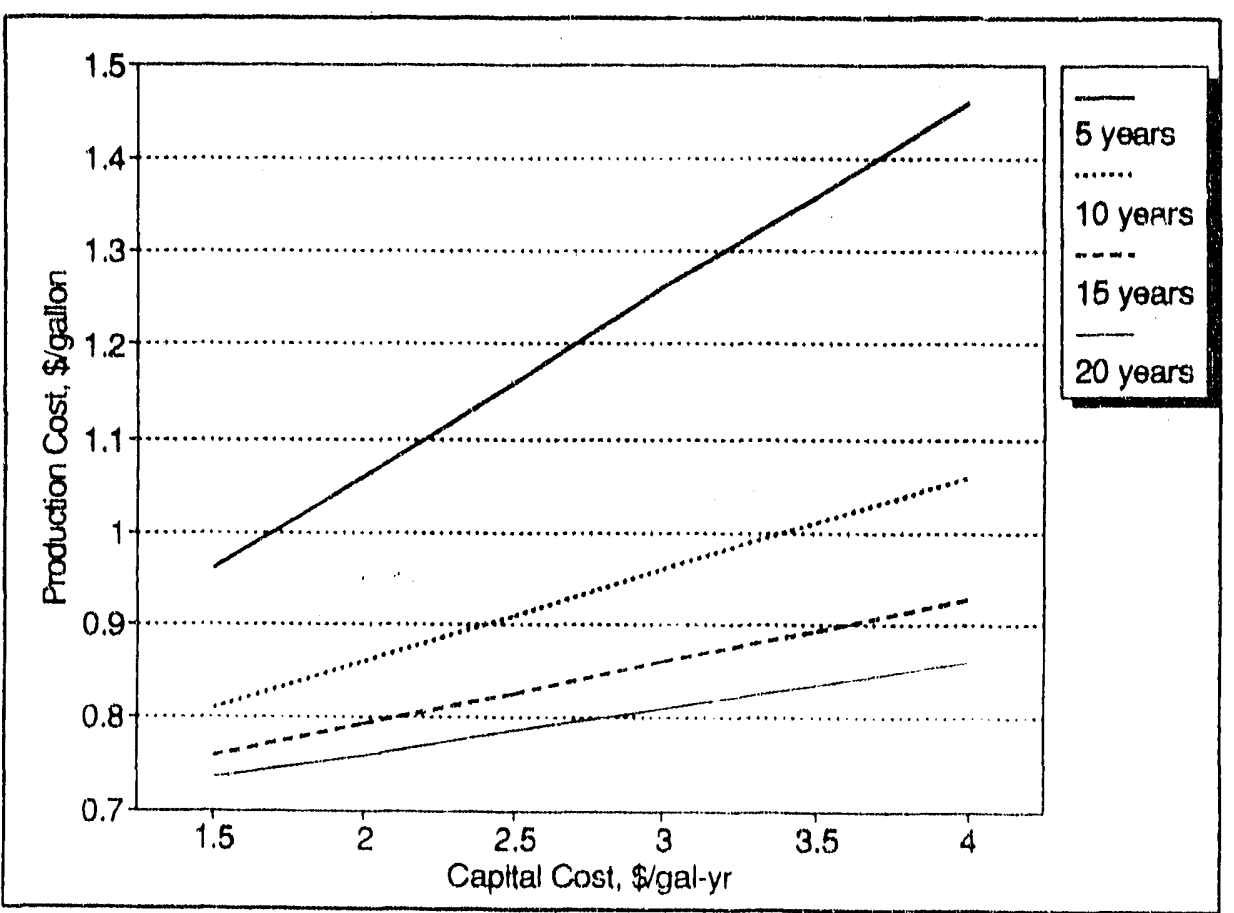

Figure 10. Sensitivity of ethanol production costs to capital costs and depreciation period. 


\section{Revenues from Sale of Ethanol}

As will be shown in the next section, revenues are the most important factor affecting profitability. The selling price for ethanol fuel depends on wholesale gasoline prices, federal and state incentives, and marketing costs. Marketing costs and incentives are falrly well defined. Gasoline prices are, and probably will be, volatile. Federal incentives are currently worth $\$ 0.54$ per gallon of ethanol when blended with gasoline and are scheduled to sunset on December 31,2000. State incentives will be worth \$(0.37/gallon beginning in April 1991 but are scheduled for sunset on December 31, 1992. Marketing costs vary between $\$ 0.20$ $0.30 /$ gallon of ethanol and provide the incentive for gasoline stations to sell ethanol blended fuels. The ethanol selling price is assurned equal to the wholesale gasoline price plus $\$ 0.70$ to account for incentives and marketing costs.

The future price of wholesale gasoline and thus the price of ethanol fuel cannot be accurately predicted. However, by assuming that gasoline prices will vary as they have in the period 1978 through 1990 the expected distribution of ethanol prices can be computed. Figure 11 shows the cumulative frequency distribution of wholesale gasoline prices over the past thirteen years and provided the basis for determining the probability of wholesale prices exceeding a particular value. For example, over the past thirteen years the wholesale gasoline prices have been greater than $\$ 0.55$ per gallon 80 percent of the time. Ethanol prices would be higher by the value of the incentives available.

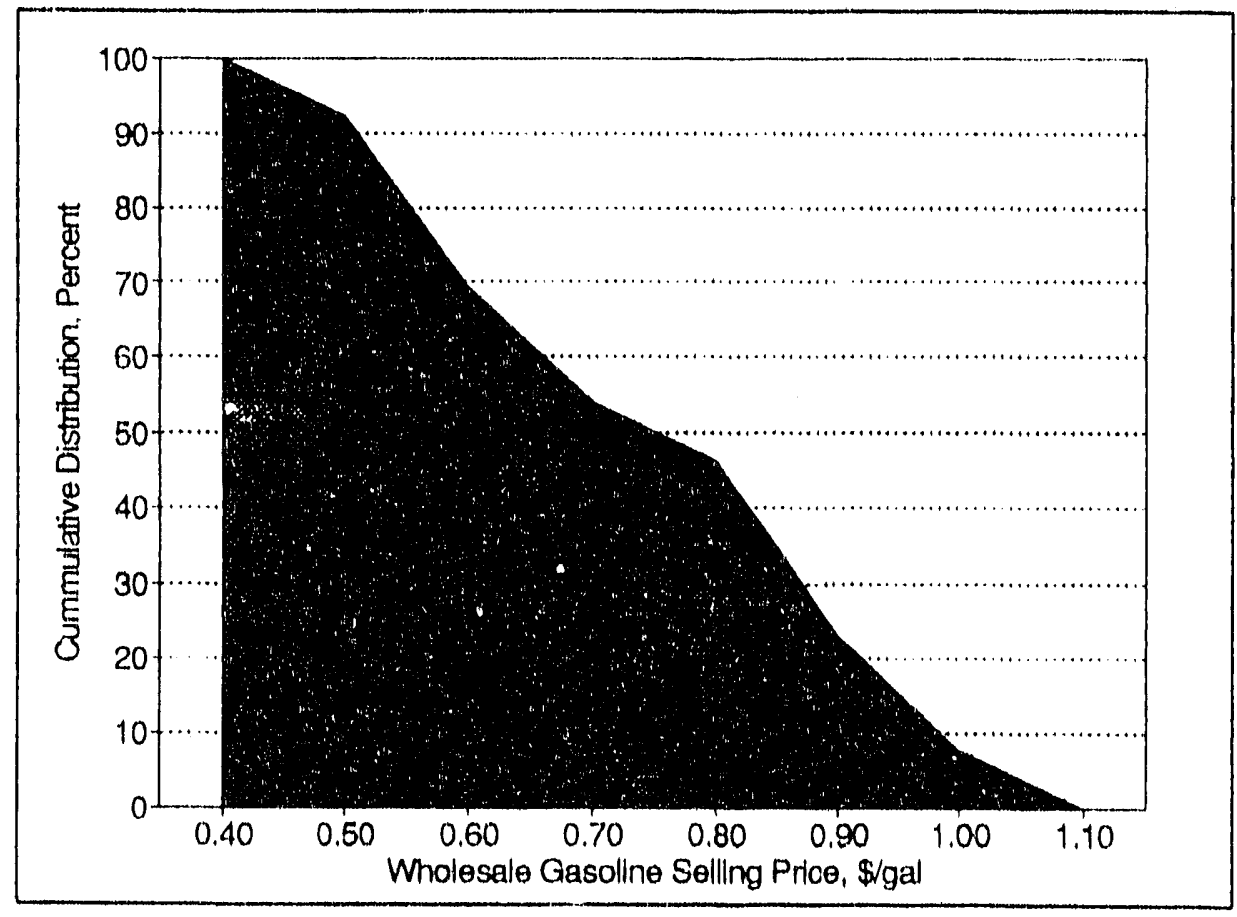

Figure 11. Cumulative distribution of United States wholesale gasoline prices, 1978-1990. (Energy Information Administration) 


\section{Return on Investment}

The profitability of a venture to produce ethanol fuel from mixed waste paper can be represented by the return on investment (ROI). The return on Investment is the rutio of net income after federal taxes to the dollars invested in the project. Table 12 shows the various factors that are used to compute the ROI and the values for our base case. Revenues result from the sale of the ethanol fuel and any by-products. Expenses include the cost of the mixed waste paper(feedstock cost), labor, chemicals, maintenance(O\&M costs), and depreciation costs. Depreciation is not a cash expenditure but represents the return of the capital that is invested. The difference between revenues and expenses is the gross revenue. Federal taxes are paid on the gross revenue. The amount of taxes paid is equal to the tax rate times the gross revenue less any applicable tax credits. The difference between gross revenue and taxes is the net inco.ne. The net income divided by the capital invested is the return on investment.

The ROI is calculated using the following equation:

$\mathrm{ROI}=100 \times[$ (revenues - expenses $) \times$ tax rate + tax credit $] /$ capital

where:

$$
\begin{array}{ll}
\text { Revenues } & =\text { wholesale gasoline price + incentives + by-products } \\
\text { Expenses } & =O \text { \& } M \text { - feedstock/yield - capital/depreciation period } \\
\text { Capital } & =\text { Capltal cost per gallon of annual capacity } \\
\text { Tax Rate } & =\text { federal income tax rate } \\
\text { Tax Credit } & =\text { federal tax credits }
\end{array}
$$

Table 12

Factors Determine Profitability

Economic Factor

Revenues

Ethanol

By-products

Expenses

Feedstock

Depreciation

Gross Income

Federal Taxes

Tax Credits
Operations and Maintenance

\$/gallon ethanol

1.29

1.24

0.05

0.86

0.21

0.45

0.20

0.43

0.14

$-0.07$

Net Income

0.36

Return on Investment, \% 
Figure 12 shows the expected plant gate selling price for ethunol fuel as 4 function of wholesale gasoline prices. The state incentive of $\$ 0.37$ is scen as major factor in the two possible selling prices shown in the figure.

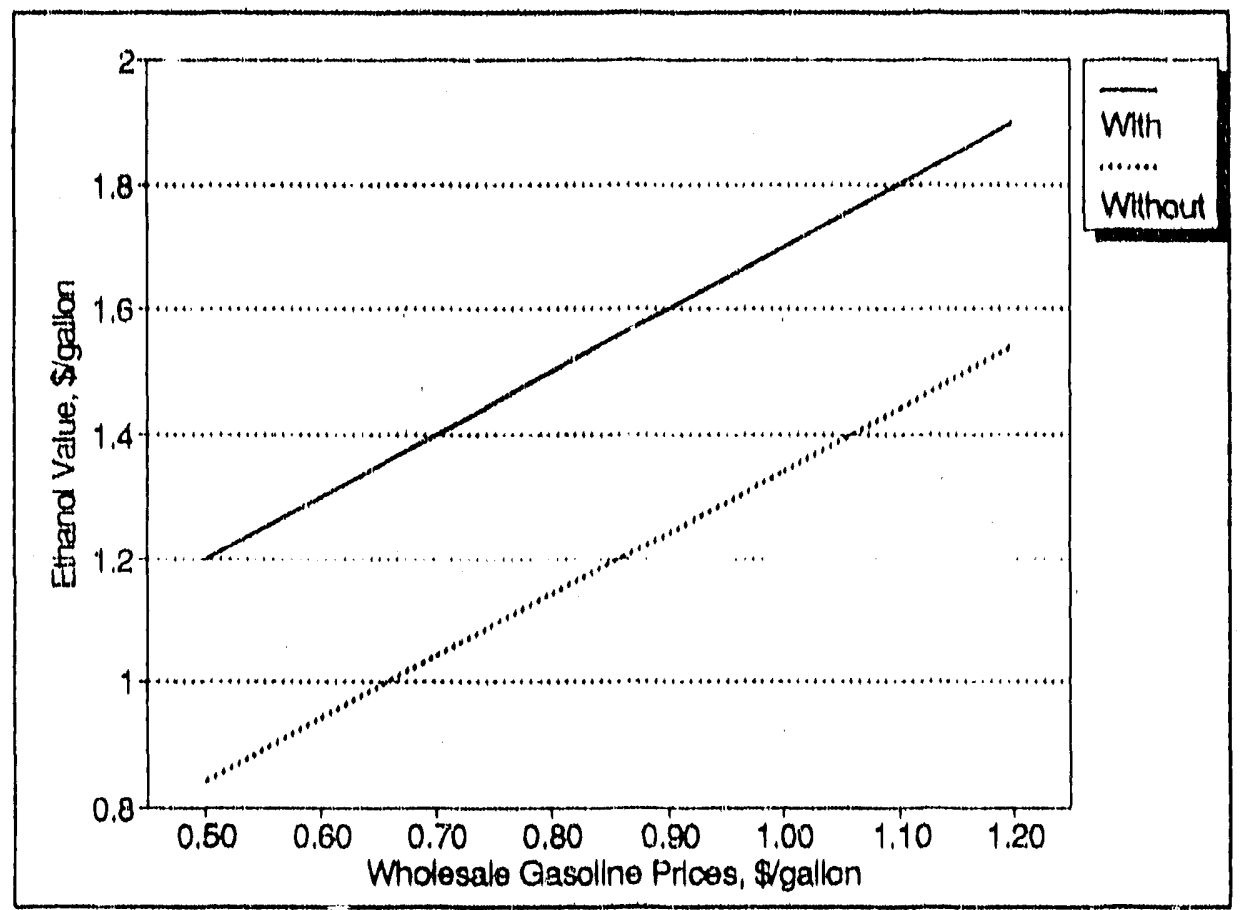

Figure 12. Relationship between wholesale gasoline prices and ethanol fuel selling price with and without state tax incentive. 
Figure 13 shows the sensitivity of return on investment to a 10 percent change in the various cost and revenue components. The selling price of ethanol is the most sensitive component. A ten percent increase in selling price would increase the $k O S$ by 23.6 percent. Since the base case ROI is 12 percent, the increased selling price would yield a 14.8 percent ROI. On the cost side, capital cost is the most sensitive factor. A ten percent increase in capital cost would give a 12.5 percent decrease in ROI, down to 10.5 percent.

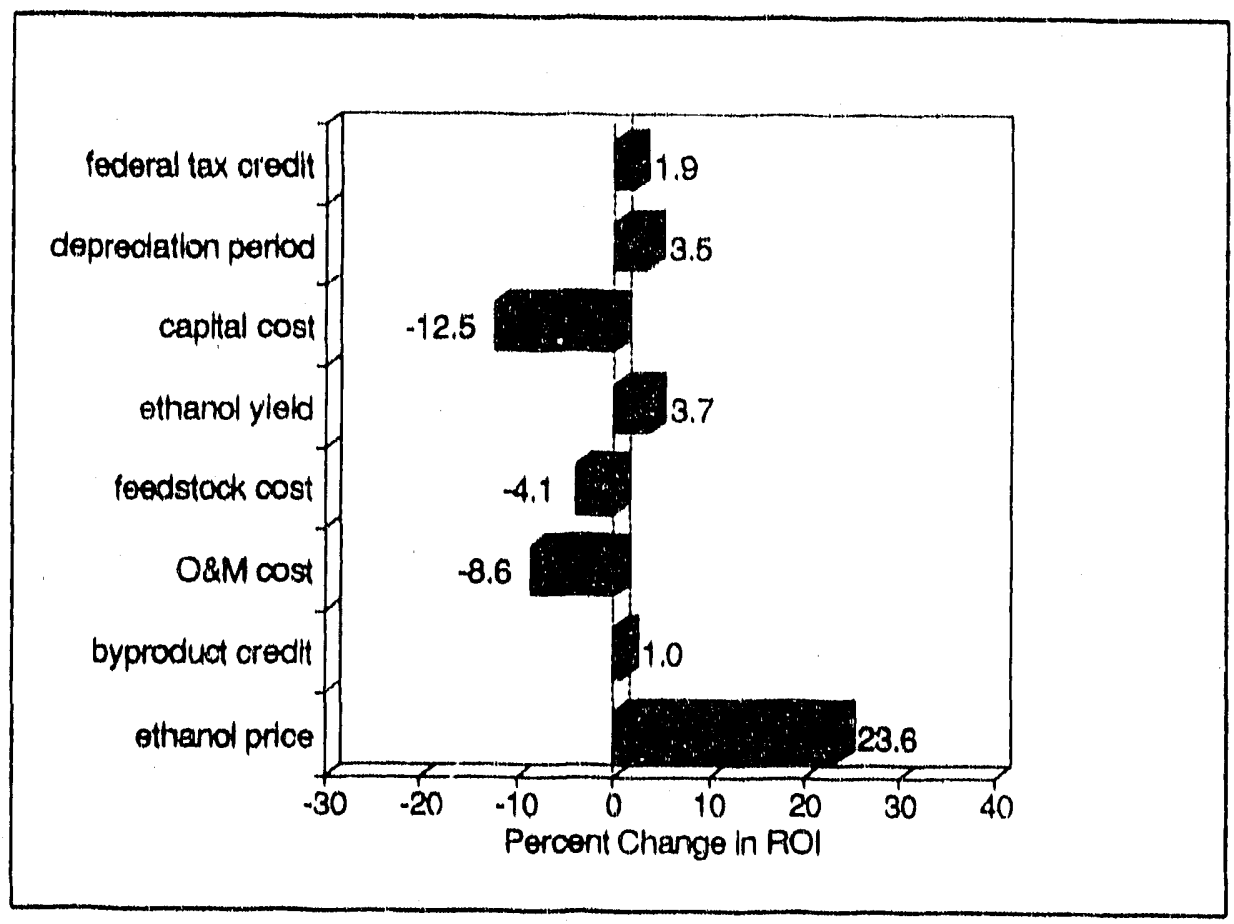

Figure 13. Sensitivity to change after tax return on investment from base case for a ten percent change in revenue and expense variables. 
Return on investment depends on all the variables in the ROI equation given above. It is possible to calculate the probability of a particular ROI based on wholesale gasoline prices. Figure 11 showed the historical probability of wholesale gasoline prices. A return on investment can be calculated for a particular gasoline price. The probability of equalling or exceeding the calculated ROI is equal to the probability of that wholesale gasoline price. The effect of changes in capital costs, O\&M costs, feedstock costs, and state incentives on ROI for various wholesale gasoline prices are shown in Figures 14 to 16. The probability is based on gasoline prices and not on the probability of a change in capital, feedstock, or other costs.

An example will help explain how to interpret the results. Figure 14 shows the effect of changes in capital cost on ROI. The base case assumed a capital cost of $\$ 3.00$ per gallon of annual capacity. There is a 60 percent probability, based on wholesale gasoline prices, that the ROI will be equal to or greater than twelve percent. If the capital cost were $\$ 4.00$ per gallon of annual capacity, there would be a 60 percent probability that the ROI would be equal to or greater than nine percent. Likewise, there is a 100 percent probability, again based on the predicted price of gasoline, that the ROI would exceed 21 percent if the capital cost were $\$ 1.50$ per gallon of annual capacity.

Since one reason for producing ethanol from mixed waste paper is to create a market that may pay higher prices for paper, its impact on ROI is important. Figure 15 shows the effect of mixed paper prices on profitability. There is a 100 percent probability that the ROI will be greater than 4 percent for a $\$ 30 /$ ton feedstock cost and greater than 10 percent for $\$ 10 /$ ton feedstock.

The importance of the state incentive on profitability is shown in Figure 16. The ROI would decrease eight percentage points if the state incentive were removed. For the base case, and a fifty percent probability based on wholesale gasoline prices, the ROI would decline from 16 to 8 percent.

\section{Summary}

On the basis of the figures presented above the production of ethanol fuel from nixed waste paper appears to be promising. Even for the worst case of no state incentive the project would break even at the lowest gasoline prices seen in the last thirteen years. On the upside, if the state incentive does not expire December 31,1992, the probability of the after tax. ROI exceeding sixteen percent is 50 percent. There still remains the need to get better estimates of the capital and operating costs for an actual facility. 


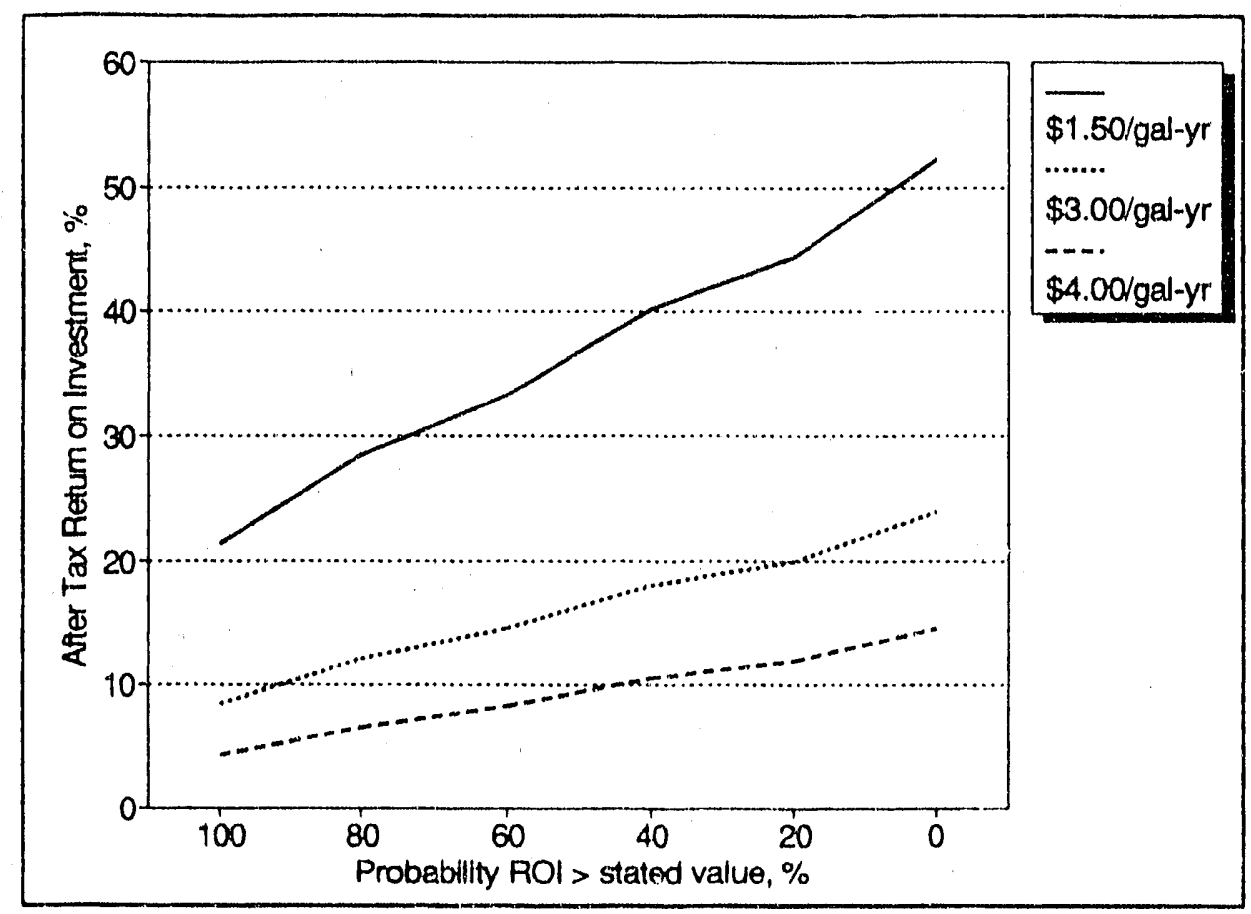

Figure 14. Probability of an after tax return on investment based on historical wholesale gasoline probabilities and the effect of capital costs.

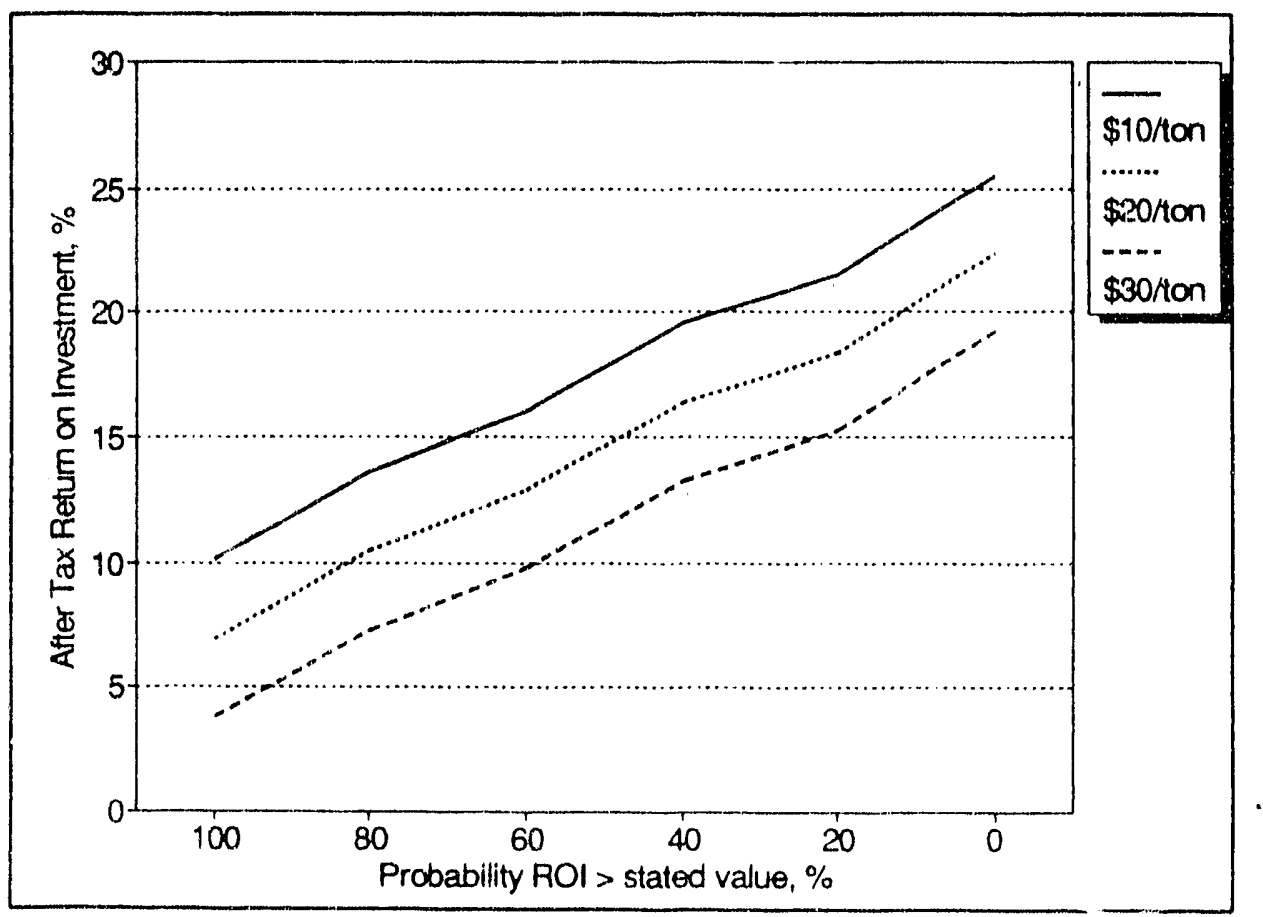

Figure 15. Probability of an after tax return on investment based on historical wholesale gasoline probabilities and the effect of feedstock costs. 


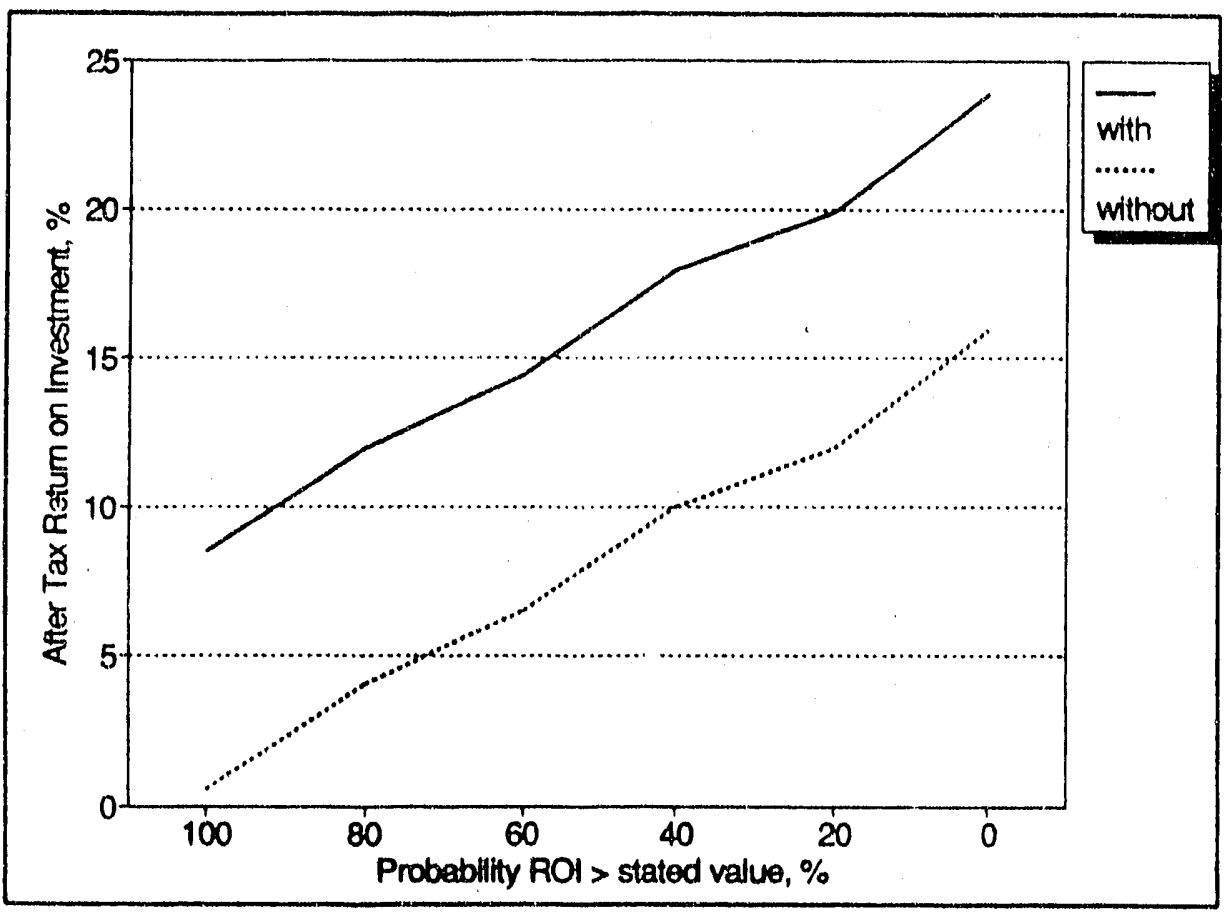

Figure 16. Probability of an after tax return on investment based on historical wholesale gasoline probabilities and the effect of state incentives. 


\section{Market Entry Opportunities}

The science and technology are available to convert mixed waste paper to ethanol fuel. The gasoline fuel market could nse all the ethanol that would be produced. The profitability looks promising.

Why then is no one building a facility? There are several reasons. The future price of gasoline and thus the price of ethanol fuel is very difficult to predict. There are no operating demonstration facilities for any technology. Thus the technology and economic risks of designing, building, and operating a commercial facility are high.

One of the challenges in getting a technology commercially accepted is to find locations that offer inarket entry opportunities. Characteristics of a good entry point include facilities that already have some of the conversion or auxiliary equipment, experience marketing the products, a disposal problem with materials similar to the feedstock, and easy access to or control of the feedstock.

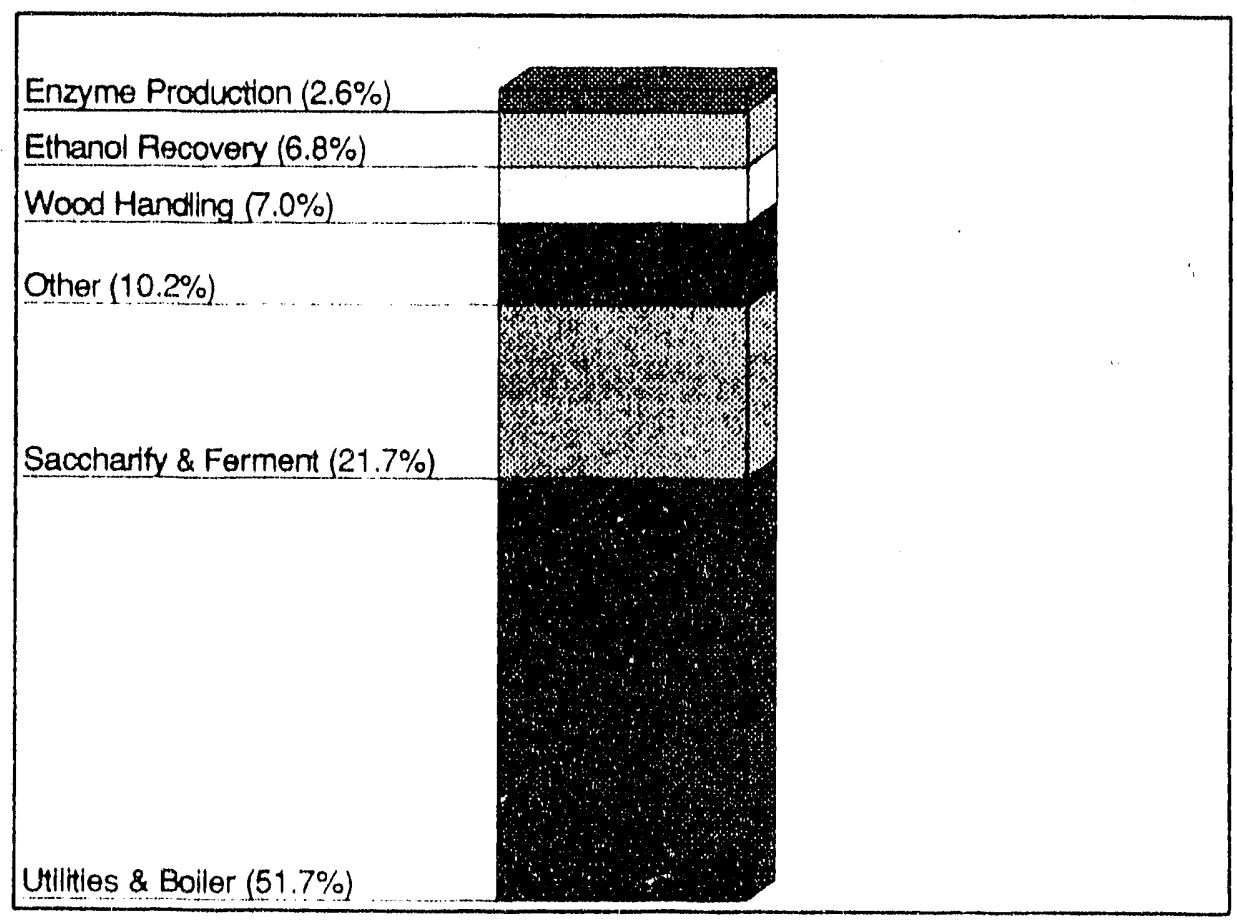

Figure 17. Percentage contribution to the capital cost of major components for a grass roots cellulose to ethanol facility. 
Lower capital costs can improve the profitability of a conversion plant. One way to achieve lowes costs is to locate a facility that already has some of the equipment on site. Figure 17 shows the approximate contribution to the capital costs for a grass roots cellulose to ethanol facility. Major cost items include the boiler system and fermentation systems. Pulp mills often have excess boiler capacity that could be used to burn the non-fermentable residues from the mixed paper. If a boiler system did not have to be purchased the capital cost could be reduced from $\$ 3.00$ per gallon to $\$ 2.00$ per gallon of annual capacity. The effect of the reduced capital cost would result in an increase in an increase in the ROI from 16 to 27 percent.

The effect of having a similar feedstock material that must be disposed of and thus has a negative feedstock is shown in Figure 13. The sludge from Weyerhaeuser showed yields of 25 gallons per ton. This is substantially lower than the 70 gallons per ton from mixed waste paper, but if the sludge is available at zero or negative cost, the contribution of feedstock cost to the cost of production is reduced substantially. The effect on profitability is also substantial with ROI going from 21 percent at a zero cost for sludge up to 39 percent if sludge disposal costs $\$ 20$ per ton.

One other market entry point could be at existing or new ethanol fuel production facilities. These sites would have fermentation and distillation equipment plus a trained staff. The Georgia-Pacific pulp mill in Bellingham has these characteristics.

Table 13

\section{Advantage of Using Sludge as Feedstock}

\section{Feedstock Characteristics}

\begin{tabular}{lrcc} 
Type & $\begin{array}{c}\text { Cost } \\
\text { \$/ton }\end{array}$ & $\begin{array}{c}\text { Yield } \\
\text { gal/ton }\end{array}$ & $\begin{array}{c}\text { ROI } \\
\%\end{array}$ \\
\hline Mixed Paper & 15 & 70 & 16 \\
Sludge & 0 & 25 & 21 \\
Sludge & -10 & 25 & 30 \\
Sludge & -20 & 25 & 39
\end{tabular}




\section{Remaining Issues and Recommendations}

This repor shows that mixed waste paper can be converted to ethanol fuel using existing technologies. The market for ethanol fuel is far from saturated and could use all the ethanol that is produced. The federal and state incentives make the economics look promising and the federal incentives will remain in effect for ten more years. The supply of mixed waste paper is expected to increase with no new markets readily apparent. Thus, the price of paper should remain stable.

\section{Issues}

1. The technology and economic conclusions are based on laboratory and small pilot scale facilities. More detailed engineering and economic analysis are required before an investor would feel comfortable building a commercial sized facility.

2. The cost of producing ethanol from mixed paper does depend on the size of the facility. Larger plants offer economies of scale. It is necessary to determine the optimum sized facility for Washington.

3. The environmental impacts of using mixed waste paper to produce ethanol have not been evaluated. There is no reason to believe a problem would exist but the issue should be addressed.

4. The need to demonstrate the technology at a larger scale is required. Finding a facility that already has some of the required equipment would reduce the cost of such a demonstration.

\section{Recommendations}

1. The results of this report should be distributed and presented to mixed waste paper suppliers and to potential conversion facilities and an effort made to work cooperatively.

2. Efforts should be made to seck federal involvernent in the demonstration of the technology at a Washington facility.

3. Capital costs and production costs should be refined for an appropriately sized facility.

4. The environmental effects of a production facility should be assessed.

5. The sunset date on state incentives for ethanol fuel production should be extended to December 31, 2000 to conform with Federal incentives. 


\section{REFERENCES}

Anderson, M., Washington State Petroleum Markets Data Book, Washington State Energy Office, Olympia, WA, January 1990.

Andren R.K. and Nystrom, J.M. "Cellulose - From Solid Waste to Chemical Resource", Energy from Solid Waste Utilization, Technomic Publishing Co., Westport, CT, 1975.

Barrier, J.W. et al, Production of Ethanol and Co-Products from MSW-Derived Cellulosics Using Dilute Sulfuric Acid Hydrolysis, Tennessee Valley Authority, Muscle Shoals, AL. May 1990.

DOE, "Tenth Annual Report on the Use of Alcohol in Fuels", Office of Alcohol Fuels, Department of Energy, Washington, D.C., November 1989.

Easley, C.E., et al, "Cellulosic Waste Conversion to Ethanol Using Fed-Batch Simultaneous "Saccharification and Fermentation", Energy from Biomass and Wastes, XIII, Institute of Gas Technology, 1989.

Emeret, G.H. and Katzen, R., "Economic Update of the Gulf Cellulose Alcohol Process", Chemical Engineering Progress, American Institute of Chemical Engineers, September 1980.

Energy Information Administration, Petroleum Marketing Monthly, Washington, D.C., 1990.

GAO, Alternative Fuels: Feasibility of Expanding the Fuel Ethanol Industry Using Surplus Grain, U.S. General Accounting Office, June 1987.

Hinman, N.D., et al, "Preliminary Estimate of the Cost of Ethanol Production for SSF Technology", Draft Proceedings; Ethanol from Biomass Annual Review Meeting, Solar Energy Research Institute, Golden, CO, September 1990.

Information Resources Inc., Washington, D.C., 1990, Private communication.

Lyons, J.K. and Kerstetter, J.D. Mixed Waste Paper as a Fuel: Environmental, Economic, and Market Assessments, Washington State Energy Office, Olympia, WA, January 1990.

SERI, Draft, Resource Assessment and Economic Analysis of Important Western Region Lignocellulosic Feedstocks for the Production of Fuel Ethanol, Solar Energy Research Institute, Golden, CO, May, 1990.

Wright, J.D. and Power, A.J., "Comparative Technical Evaluation of Acid Hydrolysis Processes for Conversion of Cellulose to Alcohol", Energy from Biomass and Wastes X, Institute of Gas Technology, 1986.

Washington State Department of Licensing, Prorate and Fuel Tax Services, "Monthly Gasohol Distribution", 1990. 
Appendix A

Record of Telephone Conversations and Site Visits 


\section{Telephone Conservation}

Who: Wayne Barrier

Date: November 21, 1990

Where: Company: Tennessec Valiey Authority

Address:

City, etc.: Muscle Shoals, AL

Telephone: (205) 386-2527

\section{Subject: Acid Hydrolysis}

Wayne visited Biomass International, at their invitution, to evaluate what they were doing. He said that he recommended they consider another process than the $\mathrm{HCl}$ hydrolysis route they are following. He said the advantages of $\mathrm{HCl}$ were that it is easy to recover and gives very high yields. However, on the negative side are the high cost of $\mathrm{HCl}$. He said that a loss of 1 percent of the acid would be equal to non-reuse of the 2 percent $\mathrm{H} 2 \mathrm{SO} 4$ that is used with dilute acid hydrolysis. $\mathrm{HCl}$ residues may also cause a problem in the boilers when the unfermentable material is burned. Biomass plans to use a hydropulper and Wayne thought that perhaps they should look at enzymatic hydrolysis since one of the costs with enzymatic process is the cost of pretreatment so the enzymes can attack the cellulose.

Wayne's lab has done some bench scale work on concentrated $\mathrm{H} 2 \mathrm{SO} 4$ hydrolysis of paper and obtained good yields. Most of their work is done on a 2 tpd dilute acid pilot plant.

He feels that dilute acid is the process most near to commercial status, perhaps 2-3 years. It does not necessarily of fer the best yields but it is closest to commercial status. He thinks it will be 5 years for concentrated acid systems and longer for enzymatic hydrolysis unless the cost of producing the enzymes can be reduced.

He would like to build a 150-200 tpd dilute acid demonstration plant before designing a full scale commercial facility. The estimated cost to build and operate a demo plant is $\$ 50$ million. 


\section{Telephonc Conservation}

Who: Roger Bond, VP linunce

Date: November 2, 1991

Where: Company: Biomass One

Address:

City, etc.: Ogden, Utah

Telephone: $801-392-1486$

Subject: Status of Project

They are 50 percent completed on their 56 tpd MSW to ethanol demonstration pilot plant. They expect to accept material within six months. The 56 tpd represents the modular size for their commercial facilities.

They will produce an RDF type of material from mixed garbage that will then undergo concentrated $\mathrm{HCl}$ hydrolysis. They contructed with a Delaware company to provide the acid recovery equipment. They expect an 85 percent recovery of fermentable sugars.

The dermonstration unit is projected to cost $\$ 4$ million. Initially they had planned to spend $\$ 1$ million. They are working to obtain funds for completion of both the demonstration plant and the cormmercial plant (500 tpd). 


\section{Telephone Conservation}

Who: Peter Daily, Director of Research

Date: September 17,1990

Where: Company: Chemical Waste Diviston is ate Management

Audress:

City, etc.: Illinois

Telephone: (708) $513-4500$

Subject: Conversion of Paper to Energy Products

Peter is the director for research activities carried ou by Waste Mangement Corp. His annual budget is $\$ 15$ million.

They are currently working on a demonstration facility to convert sewage sludge and waste paper to a pelletized coal substitute. He expects to have a commercial contract within six months. The advantage of the process is it may provide a market for sludge.

They are cooperating with Genacor on the development of cellulase enzymes. Genacor is a cooperative venture with Genatech, Kodak, und Finnsigar. They hope to have a cost effective enzyme by 1993.

He favors enzymatic hydrolysis because of the opportunities for advancement over acid hydrolysis. 


\section{'Telephone Conservation}

Who: Wayne Edwards

Date: November 1,1990

Where: Company: Levelton and Assordintes

Address:

City, etc.: Vancouver, BC

Telephone: (604) 266-1411

Subject: Ethanol from Sawdust Study

Wayne had a contract from the Canadian Energy, Mines, and Resources division to prepare a report on ethanol production from saw mill waste. He evaluated both dilute acid and enzymatic hydrolysis. He also surveyed saw mills to determine their interest in such a venture.

Wayne used BIOSIM as the model to perform the calculations and the New Zealand process for acid hydrolysis and the Arthur D. Little study done for NYSERDA on enzymatic hydrolysis.

Copies of the report are avalable from Ed Hogan of Energy, Mines, and Resources 613-996-6226. 


\section{'Telephone Comservation}

Who: Dr. George Emert

Date: November 29, 1990

Where: Compuny: Auburn Universily

Address:

Cily, elsi: Nubama

Telephone: (205) 844-4()(x)

Subject: Enzymatic Hydrolysis

Dr. Emert is now Executive Vice-President at Auburn University. He previously worked at the University of Arkansas and was responsible for developing the Gulf Oll Company enzymatic process for converting cellulose to ethunol. He said that back in the late 1970's Gulf identified the Puget Sound area as the best location in the country to bulld a commercial facility. The reason was the large number of pulp mills that had barge access.

He said that the recent Proctor and Gamble study was done at a scale large enough to perhaps build a commercial facility capable of processing 600 tpd of feedstock. Ray Katzen would know the details. His work in the 1980's is still considered state of the art and the enzymatic process they developed has been improved upon but is still basically what they did at their 1 tpd pilot plant.

The University of Arkansas is still capable of doing enzymatic research but their level of support is basically inadequate. Dr. Kurt Bevernitz is running the facility (501-575-6299) 


\section{Telephonc Conservation}

Who: Ray Kutzen

Date: $\quad$ November 30,1990

Where: Company: Raphuel Katzen Assuciates

Address:

City, etc.: Clncinnati, $\mathrm{OH}$

Telephone: (513) 351.7500

Subject: Proctor \& Gunble Project

Katzen and Associates has been working on ethanol fuel projects for 50 years. Ray Katzen was involved in the Georgia Pacific project in the 1940's. Katzen was the engineering firm working for Proctor and Gamble Paper Company when th sy were evaluating the recovery of ethanol from pulp mill waste.

Ray said that they designed a 60-80 tpd facility that could handle to pulp mill sludge generated at P\&G mill. The operation would have been profitable, even at that small scale, because of the high sludge disposal costs. No capital cost or operating data was given.

Katzen planned to use the 60 tpd facillty as a dermonstration plant to get engineering data that could be used to design a 1000 tpd conmercial facility. The pilot plant they did run was sized at about 3 tpd.

Katzen thinks the two areas needing the most wc rk are pretreatment and reducing the cost of enzyme production. They found impact milling and other thermomechanical processes to most cost effective. They favor these over chemical pretreatments. 


\section{Telephone Conservation}

Who: Professor George Lightsey

Date: November 2(0,199()

Where: Company: Mississippi State Universily

Address:

City, etc.: Mississippi State, Miss.

Telephone: (601) 325-2275

Subject: Strong Acid Hydrolysis

George is getting funding from TVA to run the strong acid hydrolysis unit. They also have done some recent work on characterizing RDF as a boiler fuel. They find relatively large quantities of PVC which could cause problems. There next project will be to determine ethanol yields using concentrated acid hydrolysis.

There first try at using concentrated $\mathrm{H} 2 \mathrm{SO} 4$ with RDF was not successful. They only obtained a yield of 30 percent. The RDF behaved quite different than their previous experience with wood. Woody material was hard to wet whereas the RDF sort of soaked up the acid.

Their general process is to use 10 percent acid as a pretreatment method. They then add more acid to get a 35 percent concentration. This is then dried to increase the concentration to 70 percent and thus effect the hydrolysis of cellulose.

He has not worked with $\mathrm{HCl}$ but knows the cotton industry uses it to remove cotton linters from the seed. The process is used in Arizona where the climate is dry but did not work well in Mississippi because of the high ambient moisture and the consequent corrosion of materials. The industry uses $\mathrm{H} 2 \mathrm{SO} 4$ in MS.

Wayne Barrier just returned from Utah where he evaluated the Biomass International technology. TVA folks also say that Gaddy is ready to commercialize his acid recovery system?

Dr. Hester at the Univ. Southern Mississippi has a graduate student working on a polymer resin that can be used to recover acid. The results look promising. 


\section{Telephone Conservation}

Who: Dr. Don Potts

Date: November 8,1990

Where: Company: Diversified Industries

Address:

City, etc.: Canuda

Telephone: (416) $922-5100$

Subject: Mixed Paper to Ethanol

Two years ago his company looked at wood waste to ethanol using sawdust at $\$ 44 /$ ton and the production cost was $\$ 0.44$ /iter. They they did a more comprehensive study with a Swedish pulp company and the results indicated a production cost of $\$ 1.00 /$ hiter. They then looked at putting the operation at an existing mill and the cost was $\$ 0.80 /$ liter. Finally they considered using waste fiber from a pulp mill and the cost estimate was $\$ 0.35 /$ iter.

They consider fines and additional waste paper material as a good choice if situated at an existing mill.

His company is investigating using a plug flow reactor that was developed for converting starch to sugars. So far they can orly get a 5 percent slurry of paper in the pipe reactor. With wood they could get 17 percent. Equipment modification is the purpose of their study with the Ministry of Energy.

Don said that the Swedes have an Ethanol Development Foundation. The Swedes are also running 35 buses on 95 percent ethanol in Stockholm. The buses are modified diesels.

His company also owns several pulp mills one in Ontario and one in Port Cheron in Michigan. 


\section{Telephone Conservation}

Who: Richard Strickland

Date: $\quad$ November 8,1990

Where: Company: Tennessee Valley Aulhority

Address:

City, etc.:

Telephone:

Subject: Analysis of Paper Samples

They use a process developed at USDA Madison labs for carbohydrate analysis. They determine glucose, mannose, and xylose. They method is reproducible but not exact. The method is critical to technique.

They just got data back on an RDF, newsprint, and cardboard samples. The results were as follows:

RDF glucose 64.9 percent, mannose 8.9 percent, and xylose 12 percent, with a remainder of 14.2 percent for ash, lignin, etc. For newsprint the numbers were 56 percent, 9 percent, 8.5 percent and 26.5 percent respectively. For corrugate they determined 68.5 percent, 9.5 percent, 10.4 percent and 11.6 percent respectively.

He offered to have our three samples analyzed for free. He needs about 5-10 gram samples and could get them done with two weeks of receiving them. 


\section{Telephone Conservation}

Who: Gabriel Teodosiv

Date: November 2, 1990

Where: Company: Ministry of Energy

Address: 56 Wellesley St. W.

City, etc.: Toronto, Ontario M7A 2BT

Telephone: (416) 327-1258

Subject: Mixed Paper to Ethanol Study

The Ministry of Energy is jointly funding two companies to investigate the conversion of mixed paper to ethanol. Each company has a different pretreatment process. One is enzymatic and the other weak acid

The project is just beginning and they have picked the feedstock for investigation. One company is Stake Technology and they will use enzymatic hydrolysis. The other company is Biohol, a subsidiary of Diversified Industries. Biohol will use plug flow acid hydrolysis.

They budget is $\$ 250,000$ for each company. They project is to be completed in November 1991. The companies said that they would move toward commercialization using the technology that proves to be best.

The contacts are Stake Dr. Ernest Yu 416-455-1990 and Dr. Don Potts of Diversified Research at 416-922\%5100. 


\section{Site Visit}

Who: Don Wines

Date: November 8, 1990

Where: Company: Georgia-Picific Corp.

Address:

City, etc.: Bellingham, WA

Telephone: (206) 733-4410

Subject: Spent Pulping Liquor to Ethanol

Georgia-Pacific Corp. has been recovering ethanol from their waste pulping liquor since the 1940 's. They sold the idea to the U.S. Government to install the equipment to recover ethanol that could be used to make synthetic rubber. The facility was built in one year and has been operating since.

The GP facility is unique because it uses calcium bisulfite as the pulping liquor and their is no chemical recovery boiler. The sugars that are released in the pulping process are thus available for recovery and fermentation.

The fermentation is a continuous process, one of the first in the US. The beer has a 4 percent alcohol concentration. Diethyl ether is used as the entrainer to break the azeotrope. Several years ago GP supported some research at the University of Washington to develop a yeast that could be used to convert the xylose sugars to ethanol. No economic mearis was found.

The sugar stream is about 75 percent $C 6$ sugars and 25 percent C5 sugars. The total sugar concentration is 5-6 percent sugar.

Dilute acid has a difficult process control because of sugar degradation. The Cedarquist process developed in the 1930's has been improved by the Swedish Pulp industry. Mr. Stone of Canada was promoting the process several years ago. Don offered to buy sugar from his process that he could set up a pilot operation at the Bellingham facility. John Stone can be reached at 819-777-5135.

Kraft mills use an alkaline process and thus there is little hydrolysis of material to sugars. ITT has a sodium based process in Hoquiam and they also recovery lignin. 


\section{Telephone Conservation}

Who: Dr. Ernst Yu

Date: November 20,1990

Where: Company: Stake Technology

Address: $2838 \mathrm{Hwy} \# 7$

City, etc.: Norval Ontario LOP $1 \mathrm{KO}$

Telephone: (416) 455-1990

Subject: Ethanol from Paper

They are co-funded by the Ontario Ministry of Energy to investigate the conversion of waste paper to ethanol using enzymatic hydrolysis. Stake Technology has a process of steam explosion that would be used as a pretreatment method. They recently received patents for using their process as a method of deinking paper.

They plan on using mixed office waste as the feedstock. The enzyme will come from the French Petroleum Institute. They have an enzyme with high activity and a projected production cost of $\$ 10 / \mathrm{kg}$

Mohawk Oil is interested in their process and is following their progress. Mohawk has not committed any funds at this time. 
Appendix B

Carbohydrate Analysis of Mixed

Waste Paper and Sludge

performed by Tennessee Valley

Authority 
December 17, 1990

James D. Kerstetter, Ph.D.

Bioenergy Program Manager

State of Washington

Washington State Energy office

809 Legion Way, S.E., FA-11

Olympia, Washington 98504-1211

Dear Dr. Kerstetter:

The three samples: (1) Weyerhaeuser's Longview, WA pulp mill primary sludge from their screw press, (2) olympia, WA residential recycling program, and (3) the wA state office buildings recycling program, were received on Wednesday, December 5. Compositional analyses were performed using a concentrated sulfuric acid, spectrophotometric method developed by the Forest products Laboratory in Madison, Wisconsin. The analyses have been completed and are presented below.

SAMPLE IDENTIFICATION

SAMPLE IDENTIFICATION

SAMPLE IDENTIFICATION
Weyerhaeuser's Longview, WA pulp mill

primary sludge from their screw press:

$\begin{array}{llc}\text { MEAN GLUCOSE } & 22.08 \\ \text { MEAN MANNOSE } & 5.7 \\ \text { MEAN XYLOSE } & 4.03 \\ \text { MEAN LIGNIN/INERTS } & 68.19\end{array}$

Olympia, WA residential recycling program:

$\begin{array}{llc}\text { MEAN GLUCOSE } & 55.97 \\ \text { MEAN MANNOSE } & 5.61 \\ \text { MEAN XYLOSE } & 8.32 \\ \text { MEAN } & \text { LIGNIN/INERTS } & 30.1\end{array}$

State office buildings recycling program:

$\begin{array}{llr}\text { MEAN GLUCOSE } & 68.63 \\ \text { MEAN MANNOSE } & 7.76 \\ \text { MEAN XYLOSE } & 12.35 \\ \text { MEAN LIGNIN/INERTS } & 11.26\end{array}$


James D. Kerstetter

December 17,1990

Glucose, xylose, and mannose are presented as percent sugar as an anhydride. These are estimates of the sugar potential in each sample. The carbohydrate estimates were used to derive the lignin estimates by subtraction. The mean for each sugar analysis is based on two replicates which showed little variation. The unsolubilized portion of the sample is represented in the percent lignin and other inert materials column. These can be either ash or lignin.

If there are further questions, please contact me at your convenience. My telephone number is (205)386-3607.

sincerely,

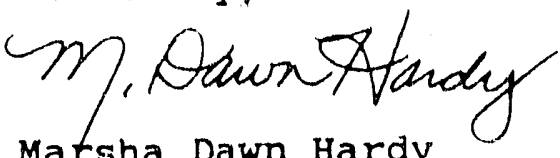

Marsha Dawn Hardy

Biotechnical Research 


\section{Appendix (:}

Enzymatic Hydrolysis Analysis of Mixed Waste Paper and Sludge

performed by Mycotech, Inc. 
HAZYKATTC HYDROLYBIB PULP MTLL

BEPARATOR BLUDGE, MXXED WABTE PAPKR

POR

WABEIMGTON BTATE BAERGY ORTICE 
Samples of pulp mill separator sludge, mixed waste paper from the olympla WA curbside residential recycling program and mixed waste paper form the Washington state ofilce bulidings recycling program were evaluated for enzymatic hydrolysis to glucose, Tests were designed as a preliminary evaluation of the potential of these materials as a hydrolysis and fermentation feedstock.

\section{Methods}

Sludge and residential, curbside samples were used as received. The state office bullding sampla was milled through a wiley Mill using a 20 mesh screen. Separator sludge was ph 6.26 in water suspension. Samples were suspended at 2 rates, $2.5 \%$ and 5\%, and each rate treated with three enzyme dose rates. Dose ratos are expressed as percent based on weight of sample. Reaction mixtures were $0.5 \mathrm{~g}$ sample or $1.0 \mathrm{~g}$ sample in $20 \mathrm{ml} .4 \mathrm{q}$ acetate buffer ph 7.8 in $125 \mathrm{ml}$ screw cap flasks. Reactions were incubated at $40^{\circ} \mathrm{C}$ in a rotary shaking water bath at 50 strokes/minute.

Mycotech's cellulase preparation, produced by solid state culture of Trichoderma reesei was used. A description of this preparation is attached. A commercial cellulase, Genencor 150L, was used for comparison at equal dcse rates.

Flasks were sampled at 20 and 40 hours, and assayed for glucose concentration using a YSI model 27 enzymatic glucose analyzer. This analyzer is specific for glucose and does not react with cellobiose, cellodextrins, xylose or mannose. To 
ensure quantitative conversion of cellobiose and callodextrins to glucose a commercial Beta glucosidase, Nova 188 was added to the reaction. Controls using only the Novo 188 were rum. These show some hydrolysis of substrate to glucose which ls lnoluded in overall conversion calculations. (In practice elther a celloblose fermenting yeast or a Beta glucosidase enzyme could be aed.)

Raw data from sample assays is reported as glucose concentration in $\mathrm{mg} / \mathrm{ml}$. Conversion efflciency is calculated by determiring the total amount of glucose produced and dividing by elther the total sample weight or the glucose potential based on the National Fertilizer and Environmental Research Center Assays. 


\section{antouthatrows}

Glucose $\mathrm{mg} / \mathrm{ml} \times 20 \mathrm{ml}$ sample volume $=$ glucose produced.

Glucose produced

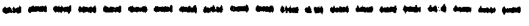

Total sample weight

$x 100 \%=$ onversion total weight

basis.

Glucose produced

X $100 \%=$ conversion

Total sample weight $x$ glucose potential glucose potential basis.

Sample caloulation:

Separator sludge $2.5 \%$ suspension, $5 \%$ enzyme at 20 hours, glucose assay $3.0 \mathrm{mg} / \mathrm{ml}$.

Total Glucose produced:

$3.0 \mathrm{mg} / \mathrm{ml}$ glucose $\times 20 \mathrm{ml}=60 \mathrm{mg}$ total glucose produced.

\& Conversion Total Weight Basis:

$60 \mathrm{mg}$ glucose

X $100 \%=12 \%$

$500 \mathrm{mg}$ sample weight

\& Conversion Glucose potential Basis:

$60 \mathrm{mg}$ glucose

$500 \mathrm{mg}$ sample weight

$X .2208$ glucose potential X $100 \%$

$=54 \%$

Glucose Potentials for the three samples are:

Separator sludge $22.08 \%$

Mixed waste paper curbside $55.97 \%$

Mixed waste paper state offices $68.63 \%$ 


\section{Results and Digoussion}

Conversion efticlency based on total welght of sample and on the glucose potentlal are shown in table 1 . Table 2 is a comparison of Mycotech and Genencor cellulase preparations at equal dose rates with results expressed in $\mathrm{mg} / \mathrm{ml}$ glucose. Table 3 shows raw data for hydrolysis results expressed in $\mathrm{mg} / \mathrm{ml}$ glucose.

In all samples conversion efficiency is greater with the lower concentrations of material but glucose concentrations are higher with the $5 \%$ suspension. Reactions appear saturated for enzyme dose at about $10 \%$. This may represent end product inhibition of the cellulase which would be reduced by continuous removal of glucose from the reaction either by membrane filtration or simultaneous fermentation. Because of end product inhibition these results tend to under-estimate hydrolysis time and conversion efficiency. Mycotech's solid culture cellulase and commercial preparations are approximatly equal in hydrolysis efficiency with these materials.

ilucose concentrations in separator sludge hydrolysis arc lower reflecting the lower glucose potentlal and high concentration of lignın and other inert material. The curbside mixed waste paper showed the highest concentration which could probably be improved by a finer milling of this material.

Suspensions greater than 5\% were extremely viscous and would be difficult to handle in stirred tank reactors. Viscosity is reduced rapidly by enzymatic hydrolysis and fed batch systems could be used to increase sukstrate loadings. 
Results for waste paper suggest that $70 \%$ conversion based on glucose potentials and $2-2.5 \%$ glucose concentrations are feasible using reasonable reaction times and economical enzyme dose rates using a low cost solid culture cellulase preparation. Assuming on average of $60 \%$ glucose potential for mixed waste paper, $70 \%$ conversion efficacy and $90 \%$ fermentation efficiency, alcohol yield per ton of waste paper could be 58 gallons.

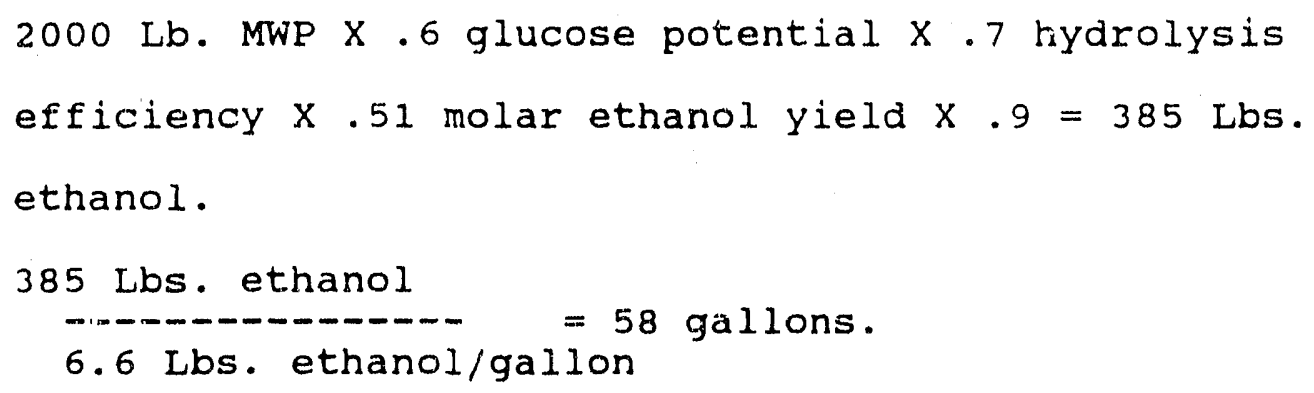

Ethanol yield from separator sludge assuming $22 \%$ glucose potential and $80 \%$ hydrolysis efficiency would be:

2000 Lbs $X .22$ glucose potential X .8 hydrolysis efficiency $\mathrm{X} .51 \times .9=161$ Lbs ethanol.

161 Libs ethanol

---.--n-.--n...

5.66 Lbs per gallon

$$
=24 \text { gallons. }
$$


TABLE 1

ENZYMATIC HYDROLYBIB WABTE PAPER, SERARATOR SLUDGE

CONVERBBION EFFICIENCY

Sample Enzyme Concentration

$x$ of substrate

$x$ of Total Weight

* of Glucose Potential

* Suspension

$20 \mathrm{hr}$

$40 \mathrm{hr}$

$20 \mathrm{hr}$

$40 \mathrm{hr}$

Separator sludge

$2.5 \%$

5
10
20

$5.0 x$

5
10
20

Mixed Uaste Peger

(Curbside)

$2.5 x$

$5.0 \%$

5
10
20

Mixed Uaste Paper

(cowercial)

$2.5 \%$

5
10
20

$5.0 x$

5
10
20

5
10
20
33

38

23

30

35

39

48

48

31

33

39
16
10

19

11

14
13

42

50

55

31

41

49

50

53

50

34

46
49

$\begin{array}{ll}54 & 76 \\ 56 & 87 \\ 60 & 87\end{array}$

$41 \quad 50$

$50 \quad 64$

59

64
61

87

64


Table 2

Comparison Mycotech

Genencor cellulase preparations

Beparator sludge (5q)

Mixed Waste Paper (curbside)

(5\%)

Mixed Maste Paper

(comercial)

(5\%)

\begin{tabular}{|c|c|c|c|}
\hline \multirow{2}{*}{\multicolumn{2}{|c|}{ Mycotech }} & \multicolumn{2}{|c|}{ Genencor } \\
\hline $2 \widehat{\mathrm{Ohr}}$ & & $20 \mathrm{hr}$ & $40 \mathrm{hr}$ \\
\hline 5.5 & 7.1 & 4.6 & \\
\hline
\end{tabular}

11.515 .3

12.315 .2

$15.6 \quad 16.9$

$14.3 \quad 17.9$ 
TABLE 3

ENZYMATIC HYDROLYBIS WABTE PAPER, BEPARATOR SLUDGE RAW DATA

Suspension Concentration

* W/Vo
Enzyme Concentration

$x$ of substrate
Glucose Concentration $\mathrm{mg} / \mathrm{ml}$

$20 \mathrm{hr}$

Separator sludie

2.5

5.0

Mixed Maste Paper

(Curteside)

2.5

5.0

Mixed Maste Paper (comercial)

2.5

5.0

Controls Beta Glucosidase onty a $20 x$

\section{Sludge 5}

Paper Curbside 5

Paper Commercial 5

$\begin{array}{ll}3.0 & 4.2 \\ 3.1 & 4.8 \\ 3.3 & 4.8 \\ & \\ 4.5 & 5.5 \\ 5.5 & 7.1 \\ 6.5 & 6.7\end{array}$

8.2

8.9

10.4

12.4

13.7

11.5

15.1

15.3

20.5

20.7

9.8

11.9

11.9

12.6

13.2

12.4

15.6

16.3

16.9

22.9

19.6

24.

$\begin{array}{ll}1.3 & 1.8 \\ 2.9 & 3.5 \\ 3.2 & 3.3\end{array}$


TABLE 1

ENZYMATIC HYDROLYBIS WABTE PAPER, BEPARATOR BLUDGE

CONVERBSION EFFICIENCY

Sample Enzyme Concentration

* of Total Weight

* of Glucose Potential

* suspension $x$ of substrate

$20 \mathrm{hr}$

$40 \mathrm{hr}$

$20 \mathrm{hr}$

$40 \mathrm{hr}$

Seperator sludes

$2.5 \%$

5
10
20

$5.0 \%$

5
10

20

Mixed Haste Paper (Curtbe ide)

$2.5 \%$

5
10

20

$5.0 x$

5
10
20

Hixed Laste Paper

(comercial)

$2.5 \%$

5
10
20

$5.0 \%$
12

13

9

13
16
19

19

11

14
13

54

56

76

87

87

$41 \quad 50$

50

64

61

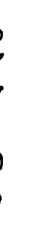

$\begin{array}{cc}10 \\ 5.0 \% \\ 20 \\ & 5 \\ 10 \\ 20\end{array}$

39

48

48

31

33

39
42

50

55

31

41

41

50
53
50

34
46
49
59

$64 \quad 89$

69

41

63

74
89
98

55
73
74

74
89
98

55
73
74

89

74

8

5
3
74

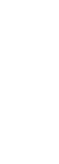




\section{MYCO TECH}

P.0. Box 4113, $630 \mathrm{Ut}$ ah Avenue

Butte, MT 59702

Ph: $(406) 782 \cdot 2386$ Fax: (406) 782.9912

CORPORATION "Enviromental Services "Biopesticides \& Agricultural Produ...j - Enzymes

January 21, 1991

Jim Kerstetter

809 Legion Way S.E., FA-11

Olympia, washington 98504-1211

Dear Jim:

Enclosed are nonproprietary excepts from Mycotechs' (then R.T.I.) report to DOE on cellulase and some cellulase data sheets. I forgot to put these in the envelope with the report sent last Friday, my apologies. The report excerpts describe hydrolysis studies on a variety of low cost or waste cellulose sources. These studies were very similar in both approach and results to the work with your samples. The data sheets provide some basic information on Mycotech solid culture produced cellulase and comparisons with conventional liquid culture cellulase.

sincerely,

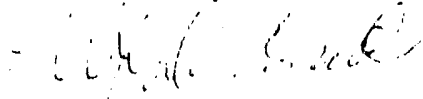

cilfford Bradley

$\mathrm{CB} / \mathrm{CW}$

enclosure

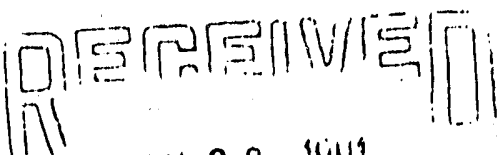

IAN $>8 \quad 19 Y 1$

WASH STALE EWERGY UFFIC, 


\section{SURMARY}

phase II demonstrated the techndcal and economic feaslbtlity or using solid state culture (SSC) of Tr1choderma reesel to prodice a low cost, crude cellulase proparation for biomass and waste celluloso collversion.

Principal technical problems were development of low cubt SSC substrates and scale-up of SSC reactors. Final substrate and reactur design achloved cellulase activity levels in crude SSC culture material. which equnl or exced all concentrated commerctal cellulase preparations. The use of SSC resulted in a significant price breakthrough. Econonic analysis denonstrated that RTI's cellulase could be marketed profitably at $1 / 10$ the price of the most cost effective commerclal cellulases. The low price opens potential markets which are uneconomical with present comercial cellulases.

Applications testing included preliminary hydrolysis and fermentation studies on a range of low-value or waste cellulose matertals, which could potentially be enzymatically hydrolyzed using a low cost collulase. Hydrolysis results with paper mill waste, paper fractions of municlpal solld waste and barley straw Indicate that conversion of these materials to ethanol is technically and economlcally feastble using RTI's SSC cellulase.

Based on Phase II results, RTI 1s proceeding with eflorts to raise private capital to support further technical narket develnpwent and construction of an SSC cellulase production plant. 


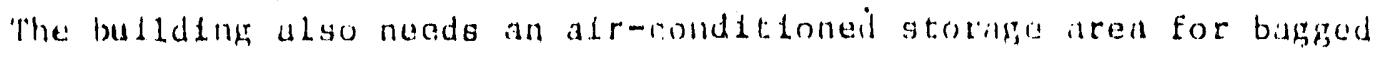
enzyme. The size of the storage area would depend on shlpptrig and sales. A $12^{\prime} \times 16^{\prime}$ room should be adequate.

The reactor room noeds to have haadrcom above the reactors. This would

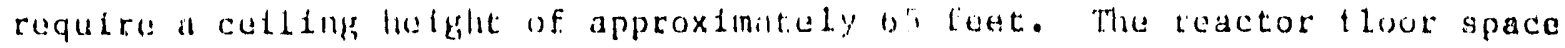
would he approximately $30^{\prime} \times 30^{\prime}$ or $10^{\prime} \times 54^{\prime}$.

The control room should be separnted Erom the proceosing areas.

It would be desirable to locatu the buliding and storage silo close to railroad tracks. This would make receiving large quantitles of barley more economical and eliminate the need for truck sales.

The building would require 440 volt, 3 -phase power. Waste process heat could supplement bullding heat.

Basod on vendur equipment cost estimates and RTI's estimates of reactor costs, total plant capital cost $1 \mathrm{~s}$ estimated at $\$ 1.31 \mathrm{~m} 111$ ion. This includes estimates for land and buildtng costs.

\section{Applications Research}

The low cost of SSC-produced cellulase opens potential markets in biomass converston which are not economical using present commercial cellulases. PreIiminary tests were conducted on a number of low value cellulosic materlals which are potential feedstock for hydrolysis and fermentation processes. Process optins for converston of these materials are elther sequential hydrolysis and fermentation or stmuitancous hydrolys ss and fermentation. Further options result from the approuch to celloblose hydrolysis and fexnentation. T. reesel cellulase preparations are low In celloblase (beta. glucosidase) activity and the predominate hydrolysis product in celloblose. Celloblose can be hydrolyzed to glucose by the addition of supplemental 
colloblase. Clucose ts then fermented by Saccharomyces. Alternatuely; juast which fermant cellobloso can be used. Tha stmplest procoss 19 stmultanuous hydrolysis and felwentiation using a celloblose fermenting yeast. Seven yeast (11sted in sectlon II) roported to ferment colloblose wore compared in a standard shake Elask fermentation ustng sulka floc. Best results were obtalned with Candida lusitanine (NRRC 5394) and Brettanomyces clausenil. (CBis 4i60) provided by slikl.

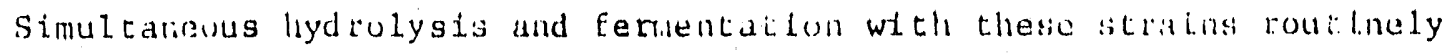
reached 3.0 to $3.5 \% \mathrm{w} / \mathrm{v}$ ethanol in $10 \%$ sollid floc at 10 to 30 fipu/gram enasme loadings. Brettonomyces generally reached higher concentrations than Candida. The system using celloblose supplement and Saccharomyces generslly produced 1.25 to $1.5 \%$ wiv ethanol. Fermentation results we re consistent despite wide variation in enzyme loadings, indicating that alcohol tulerance of cellobiose fermenting yeast may be a limiting factor.

Applications tests included hydrolysis studies and simultaneous hydrolysis and fermentation tests. Fermentations used CBS 4460) without the addition of supplemental cellobiase or a comerclal distillery yeast and the addition of cellobiase. Table 9 lists the types and sources of ccllulosic materials used in these tests. Results are described below.

1. Paper, paper Mill inaste

Paper in the form of blank nowsprint was tested as a molel for kraft process waste fiber and cellulose fraction of launicipal solid waste. Results were noor, perhaps because of the relatlvely bigh residual lignin content. The chameal solvent pulp obtalned from Biological Enorgy Corporation was more promisting. Slmultaneous hydrolysis and fermentation of this materdal reached $1.5 \%$ w/v ethanol from a $5 \%$ slurity. As a model fur solvent delignifled 


\begin{tabular}{|c|c|}
\hline Substinte & Sourca \\
\hline Newoprint (bla & Montuna Standard, Butte, MT \\
\hline Wood Pulp (organosolu process) & Blological Energy corpe Valley Forge, PA \\
\hline $\begin{array}{l}\text { Paper Mill Waste } \\
\text { (prinary clariflet sludgo') }\end{array}$ & 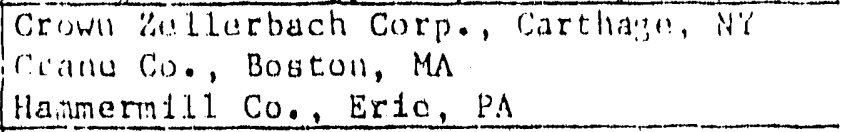 \\
\hline $\begin{array}{l}\text { Barley Strain (Nal) l'rotreated, } \\
\text { RTI) }\end{array}$ & Locil \\
\hline Wheat straw (sides plotreatment) & $\begin{array}{l}\text { Solar linurgy Research Institute? } \\
\text { (ioldon, } \mathrm{Co}\end{array}$ \\
\hline 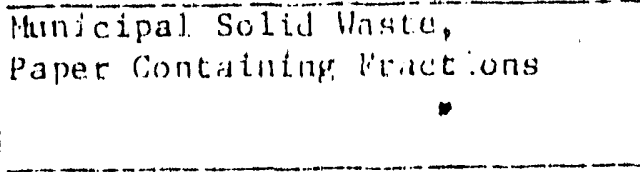 & $\begin{array}{l}\text { Gity Fllel Corpe Roca, NE } \\
\text { Undted, Blofuel Corpe, Petersburs, lA } \\
\text { Tacuma, WA } \\
\text { Buston, MA }\end{array}$ \\
\hline Corn Wet Mi iling Flber & $\begin{array}{l}\text { Archor Dandels Midland, Co, Clinton, LA } \\
\text { CPC International, Summit, IL }\end{array}$ \\
\hline
\end{tabular}

blomass, these results indicate future potontial; however, this typo of fecdstock is probably not economical for near-term ethanol production.

Paper mill waste (the off-size flber sludge from paper production) does appear technically and economically promisling as a near-term market for cellulase. Table 10 shows results of hydrolysis studies using waste sludge obtalned from three difterent paper mills. Crane Company waste is from a rag paper mill and is pribartly cotton fiber. Glucose concentrations up to 6. $7 \%$ were ubtalnet from $10 \%$ dry wejigt concentration of this material. Conversion effictency for more conventional puper inill waste was lower. Crown Zcllerbach waste wis prinary clartele: from a recycle m111 and llarimermill waste from a mill ising kraft process pulp. Results may be 1mproved with better process control, partcularly for Hammermill. Final ph was higher than apth tiun hecausn of resilual. alkall. Crown Zellerbach and Crane Company waste were evaluated fil simultaneous hydrolysis and fermentation experiments. For Crown Zellerbach, converston etiftelency at 48 hours was $29 \%$ based on dry we1ght. of the matertal at $1.6 \%$ w/v ethanol. For Crane, converston effictency 
and alcohol concentration we ro lower, $20 \%$ at $1.2 \%$ wiv ethanol. Howevur, pll was high tu these cultures. A more extenstve washthi and buflurdng procest will be required for alkaltne paper waste.

\begin{tabular}{|c|c|c|c|c|c|}
\hline \multirow[b]{2}{*}{ Sample } & \multirow{2}{*}{$\begin{array}{c}\text { Enayme Loalling } \\
(\mathrm{Epu} / \mathrm{gram})\end{array}$} & \multirow[b]{2}{*}{$2.4 \mathrm{hr}$} & \multicolumn{3}{|c|}{ (iLucuse $(m \xi / \mathrm{ml})$} \\
\hline & & & $48 \mathrm{hr}$ & $72 \mathrm{hr}$ & $91 \mathrm{hr}$ \\
\hline \multirow{3}{*}{ Crane Co. } & 7.5 & 18 & 21 & 25 & 31 \\
\hline & 15.0 & 30 & 31 & 34 & 39 \\
\hline & 30.0 & 41 & 52 & 56 & 67 \\
\hline \multirow[t]{3}{*}{ Crown Zellerbach } & 7.5 & 12 & 10 & 18 & 21 \\
\hline & 15.0 & 19 & 23 & 24 & 29 \\
\hline & 30.0 & 21 & 24 & 24 & 29 \\
\hline \multirow[t]{3}{*}{ Hanne rm 111} & 7.5 & 8 & 13 & 16 & 19 \\
\hline & 15.0 & 14 & 22 & 23 & 24 \\
\hline & 30.0 & 19 & 24 & 35 & 32 \\
\hline
\end{tabular}

Paper mill waste is a disposal problew whtch can be a signiflcant cost for some paper mills. Although the potential market is relatively small, this material is an attractive initial market for cellulase.

\section{b) Corn Wet Miling Fiber}

Corn wet milling fiber consists of corn hul 1 and residual starch separated from the corn wet miling process. About 2 million tons of tints material 1 s generated annually by the corn wet inilling lndustry and is marketed as livestock feed. This matertal is low value and as the wet miling Industry expands may saturate cattle feed markets. As a regult, value-addod procesalng of this matertal may be attractive to the wet miling industry.

Samples were obtained from CPC Interuational (CPC) and Archer Dantels Midland Company (ADM) for evaluation in hydrolysis and fermentation atudias. 


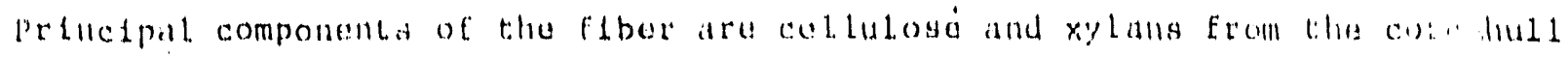
and rustdual atarch. Stareh contont was $28 \%$ for the ling samplo and $25 \%$ Lor tha ADM samplo. Converaton of hoth thareh and cellulate ta deatrablo. Sylan ut 1 hatghon would dopend on the use of xylase formenting yeast and was not Lested in this work. Hydrulgsts and fermentation atudies avaluated the addition of amylase and mixed amylaste and cellulase. In some tests, samplus were autoclaved to gelatinize starch; 1 o others, tho material was used as recclved. Amplitise used in these studies is an S\$C preparation developed by RTI which officlenty liydrolyzos ungelat Lnized gtarch.

Results are summarized ta Table 11 . In hydrolysis expertments on unconked ADM fiber, up to $28 \%$ of the dry welght matertal was converted to glucose and $38 \%$ measured as total reducing sugar. For CPC f1ber, conversions were $36 \%$ as glucose and $37 \%$ as total reducing sugar. Conversion effictency was higher when flber was autoclaved; however, the cost in commercial use could be prohibitlve. Fermentations we re run on uncooked fiber with up to $3.5 \% \mathrm{w} / \mathrm{v}$ ethanol produced in 52 hours. Ylelds were equivalent to .1 to .13 sallons of alcohol from the flber produced by the processing of one bushel of corn. Tutal potential ethanol production from current levels of fiber would be 80 tis 100 million gallons per year.

The addition oi cellulase fncreased glucose and total reducing sugar concentrations, indicating cellulose hydrolysis. The reducing sugar values probably reflect pentose reducling sugars in addition to glucose. Cellulase preparations used in these experiments contaln xylanase activity. Collulase also slgniflcantly reduces viscostty of flber slurrtes. This allowed batch feeding whlch increased ethanol concentrations. This would be a significant factor in the economica of corn wet milling fiber conversion. 


\begin{tabular}{|c|c|c|c|c|c|c|c|}
\hline \multirow[b]{2}{*}{ Source } & \multirow{2}{*}{ 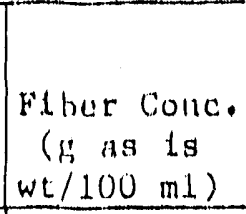 } & \multirow{2}{*}{$\begin{array}{c}\text { Dry Wt. } \\
\text { Conle. } \\
(\%) \\
\end{array}$} & \multirow[b]{2}{*}{ Linesone } & \multicolumn{2}{|c|}{$\begin{array}{c}\text { Hydrolys lou } \\
\% \text { Conversion }\end{array}$} & \multirow{2}{*}{\multicolumn{2}{|c|}{ 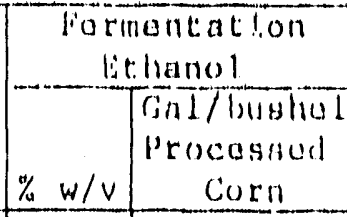 }} \\
\hline & & & & $\begin{array}{c}\text { As } \\
\text { G1 } 140080\end{array}$ & $\begin{array}{c}\Lambda s \\
t . r . s .\end{array}$ & & \\
\hline ADM & 50 & 1.99 & Amyl aryu & 27 & 31 & 1.8 & .10 \\
\hline \multirow[t]{3}{*}{ Uncooked } & 50 & 14.9 & Antyl asa/ Ce 1 Lul aso & 283 & 38 & 2.2 & .12 \\
\hline & 75 & $20.1)$ & Amylata & & & 2.4 & .10 \\
\hline & 75 & 20.0 & Anylasa/Co J. Lulaso & 27 & 34 & 2.9 & .12 \\
\hline $\mathrm{CPC}$ & 50 & 16.2 & Amylasc & 31 & 33 & 2.1 & .10 \\
\hline \multirow[t]{3}{*}{ Uncooked } & 50 & 16.2 & Amylase/Ce Llulase & 36 & 37 & 2.3 & .11 \\
\hline & 75 & 22.0 & Amylase & & & 3.3 & .12 \\
\hline & 75 & 22.0 & Amy Lase/Ce 1 Lul aso & 30 & 34 & 3.5 & .13 \\
\hline ADM & 50 & 1.4 .9 & tolyl aso & 28 & 38 & & \\
\hline Autoclaved & & 14.9 & Amylasc/CoLLulaso & 34 & 45 & & \\
\hline $\mathrm{CPC}$ & 50 & 16.2 & Amylaso & 33 & 40 & & \\
\hline Autoclaved & & 16.2 & Amylase/Cellulaso & 36 & 49 & & \\
\hline $\begin{array}{l}75 \mathrm{~g} \text { were s } \\
\text { when viscos }\end{array}$ & started at & $g / 100$ & mI with $25 \mathrm{~g}$ addit & onal fib & ver adde & ed afte & er 11 hours \\
\hline Molsture co & ontent: & $-61 \%$, & $C P C-58 \%$ & & & & \\
\hline
\end{tabular}

\section{c) Barley Straw}

Barley straw In Montana and other fiorthern Plains states is abundant and low cost, about $\$ 20$ to $\$ 25 /$ ton. Th1s is less than the $\$ 30 /$ ton feedstock cost assumed In SERI's economic analysis of large scale blomass converston. 24 Barley straw was evaluated as a model for potential large scale biomass conversion.

Straw was milled, delignifled by atutoclaving with dilute Naoll and washed. A range of $\mathrm{NaOH}$ concentrations and pretroatment condtions were tested. Table 12 shows results of liydrolys $1 \mathrm{~s}$ expurtments th which atraw was treated with $4 \%$ hydroxide at a ratlo of 15 volumes hydroxide solution per weight of straw. This table compared RTI's cellulase with the Genencor anzyme at an 


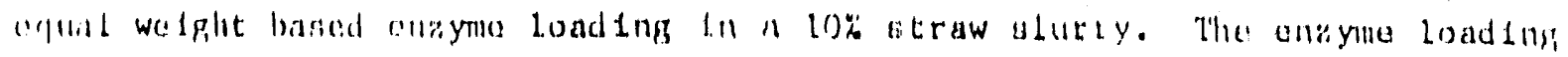

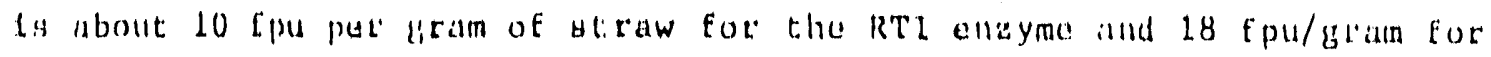
(iunoncur. Results for hoth onzymen were vary sindlar, achlauding about 70 mg/ml glucose concentration or $70 \%$ converted. Assuntag a $20 \%$ welght lose 111 Holignification and 95\% glucose fermentation efitclency, ethanol yteld would be in the range of 85 to 90 galions/an of straw. Sinultaneous hydrolystis furmentation tests with RTL's celluluse in $10 \%$ w/v straw slurry ruached $2.3 \%$ w/v ethanol in 48 hours and 2.5\% whth an equal welght dose ot Genencor cellu1ase. These testa usod a loss severe pretratinant procedure than hydrolysts tests. Enzyme loadings were the same as hydrolysis tests. Yield hased on fermentation results would be ahout 70 gallons per ton. Further work will be required to deftne the most cost effective pretreatment and yield.

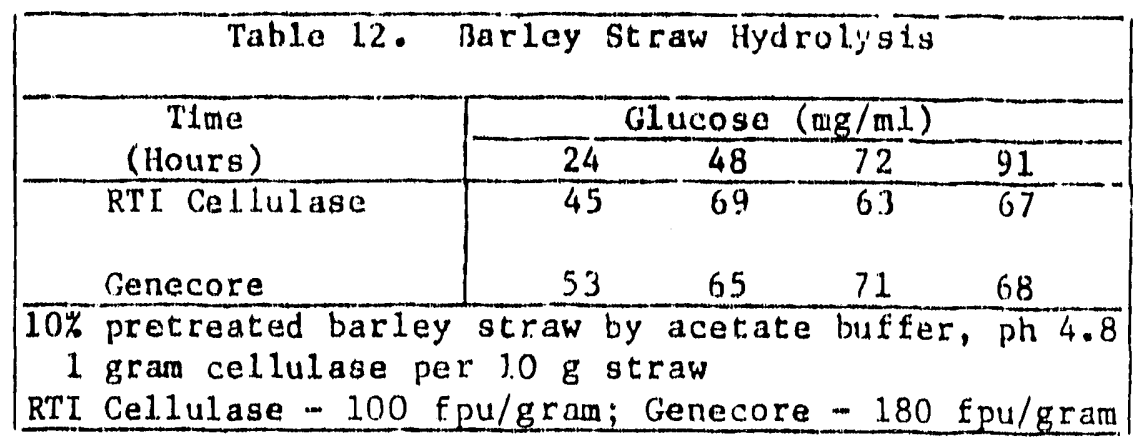

d) Municipal Solid Waste

Four of the five muntclpal soldd waste (MSW) sarples were combustible fractions or refuse-dertved fuel separated from MSW by conventional processes. The tifth sample from Clty Fuel. was produced by a proprietary separation and treatment process designed spectflcally to produce a feedstock for enzymatic hyclrolyets and formentation.

Samples were evaluated in shake flask hydrolysis experinents over a range of enzye loadings and substrate concentrations. Results are shown $1 \mathrm{n}$ 
Table 13. Viscostey was the limiting factur in substrate concentration. City Fuel samples were much less viscous and could be lindled at substrate concentrations up to $15 \%$. Conversion efficiencies measured as glucose ranged from 15 to $41 \%$ and measured as tutal reduclus: silgiar from 21 to $53 \%$ with RTL cellulase. Results with Cenencor enzyme at colual we ight unzyme doses were similar. Simultaneous hycirolysis and fermentation test: were also conducted with City Fual and United Blofuel samples. Forty-eight hour ethanol cuncentrations were $1.4 \% \mathrm{w} / \mathrm{v}$ for City Fuel and $1.6 \%$ for United Biofuel frou $10 \%$ solids slurries. Ethanol yields were lower than predicted based on hydrolysis results. Fermentations had poor yeast populations and bactorial contamination. Further work will be raquired to evaluate theso problems.

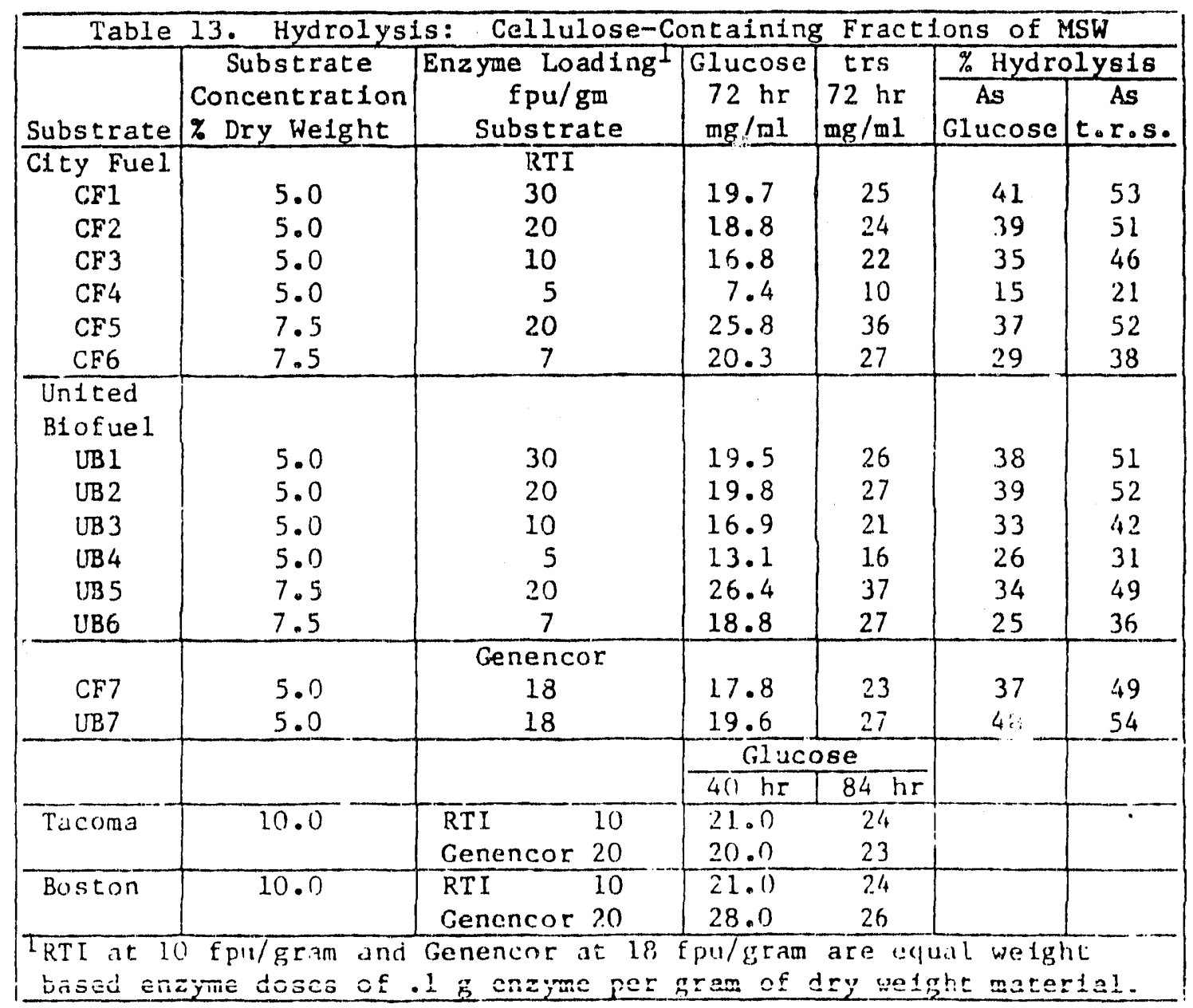




\section{MYCOLASE C - TECHNICAL PRODUCT INFORMATION}

Product Description

Mycolase C is a low cost cellulase preparation produced by soili state culture of Trichoderma reesei. The enzyme is a free-flowing, dry powide: stable for at least $s i x$ months at normal room temperatiro. Mycolase $D$ is comparable in activity levels to conmercial celdulase preparations as jirow in Table 1 below. Temperature stability up to $50^{\circ} \mathrm{C}$ and pH optima of 4.8 to 5.0 is typical of $\underline{T}$. resei cellulase.

\begin{tabular}{|c|c|c|c|c|}
\hline & $\begin{array}{c}\text { Filter paper } \\
\text { Activity } \\
\text { IU/Gram }\end{array}$ & $\begin{array}{c}\text { Carboxymethyl } \\
\text { Cellulose } \\
\text { IU/Gram }\end{array}$ & $\begin{array}{c}\text { Xylanase } \\
\text { Units } \\
\end{array}$ & $\begin{array}{c}\text { Straw Hydrolysis } \\
\text { Glucose } \mathrm{mg} / \mathrm{ml}\end{array}$ \\
\hline $\begin{array}{l}\text { Mycotech } \\
\text { Mycolase C }\end{array}$ & 140 & 444 & 272 & 5 \\
\hline Genencore $150 \mathrm{~L}$ & 218 & 455 & 240 & 25 \\
\hline $\begin{array}{l}\text { Novo } 1.5 \text { i } \\
\text { Celluclast }\end{array}$ & 144 & 407 & 88 & 21 \\
\hline Amano T.V. & 180 & 444 & 460 & -- \\
\hline
\end{tabular}

Assay procedures provided upon request.

Hycolase $C$ is typical of $T$. reesei derived cellulase preparations in haring a low cellobiase activity. For processes requiring high concentrations of glucose (rather than cellobioșe) as the end product, supplemental cellobiase activity is recommerided. Hycotech has deveioped a low cost cellobiase preparation by solid state culture of a selected strain of Aspergillus phoenicis suitable for use as a supplemental activity.

Mycotech's proprietary solid state culture technology provides very high enzyme concentrations compared with conventional dee? tank fermentations. Activity levels comparable to the best available connercial preparations are obtained with minimal processing of clilture material. The resulting unpurified preparations contain insoluble residual culture solids; ho'wever, the very low cost of this approach makes Mycolase c economical for a variety of high volume applications. Laboratory applications tests have evaluated hydrolysis of a variety of low value or waste cellulosic natezials including:

Straw

Paper Mill haste

Corn Wet Milling Fiber

Steam-Exploded Aspen
Cellulosic Fractions of Municipal Solid Waste

Silage/Ruminant Feea Additive

Efficient convezsion of these types of cellulosic materials is ungconomica! at current celiulaso prices. Hith the develonment of Mycolase C, oost effective bioccnvession of low valise or waste celiulose is possibia.

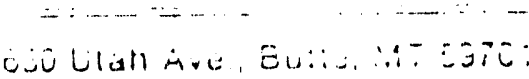
$406 ! 78: 2346$ 


\section{Introduction}

Mycolase $C^{m}$ was evaluated in comparison will cummercial collulase preparations in hydrolysis studies with steam-exploded Aspen as a substrate.

\section{Experimental}

Samples of Aspen were steam-exploded using equipment manufactured by Stake Technology (Oakville, Ontario, Canada) but not further processed for removal of lignin or hemicellulase.

Samples were delignified using $1 \mathrm{M}$ NaOH in either a "harsh" or "mild" treatment followed by hydrolysis studies using a range of enzye dose rates and substrate concentrations. Commercial cellulase preparations from Novo (Ce11uclast $1.5 \mathrm{~L}$ ) and Genencore ( $150 \mathrm{~L}$ ) were compared at equivalent weight based dose rates.

Substrate and enzyme concentrations were varied to represent potential extremes in process conditions. The mild treatment Aspan was tested in 5 and $10 \% \mathrm{w} / v$ slurries (dry welght basis delignified ispen) ar. enzyme dose rates of 2.5 to $10 \%$ enzyme based on Aspen dry weicht. The harsh treatrent Aspen was tested in a $2.75 \% \mathrm{w} / \mathrm{v}$ slurry at an enzyme dose rate of $18 \%$. All samples were suppleluented with a commercial cellobiase preparation (Novo 188) to convert soluble dextrins to glucose which was assayed using a Yellow Springs Instrument Model 27 enzymatic glucose analyzar. This cellobiase does not produce glucose from this substrate without the prescnce of cellulase.

Results are shown in Table 1 for the mild treatment and Table 2 for the harsh treatment. As shown in Table 1 , glucose concentrations of up to $5 \%(50 \mathrm{mg} / \mathrm{m} 1)$ and conversion efficlencies of up to $50 \%$ of dry weight delignifled Aspen could be obtained. Mycotech, Genencore and Novo preparations gave essentially equivalent results over the range of experimental conditiuns.

The harsh treatment Aspen at low cellulose concentration and high enzyne dose rates gave $78 \%$ hydrolysis efficiency using the Mycotech preparation and $85.5 \%$ using the Genencore preparation.

These laboratory tests indicate that Mycolase $C^{\prime \prime}$ can te used effectively in hydrolysis of steam-exploded Aspen with performance equivalent to the best avallable commercial cellulase preparations. 


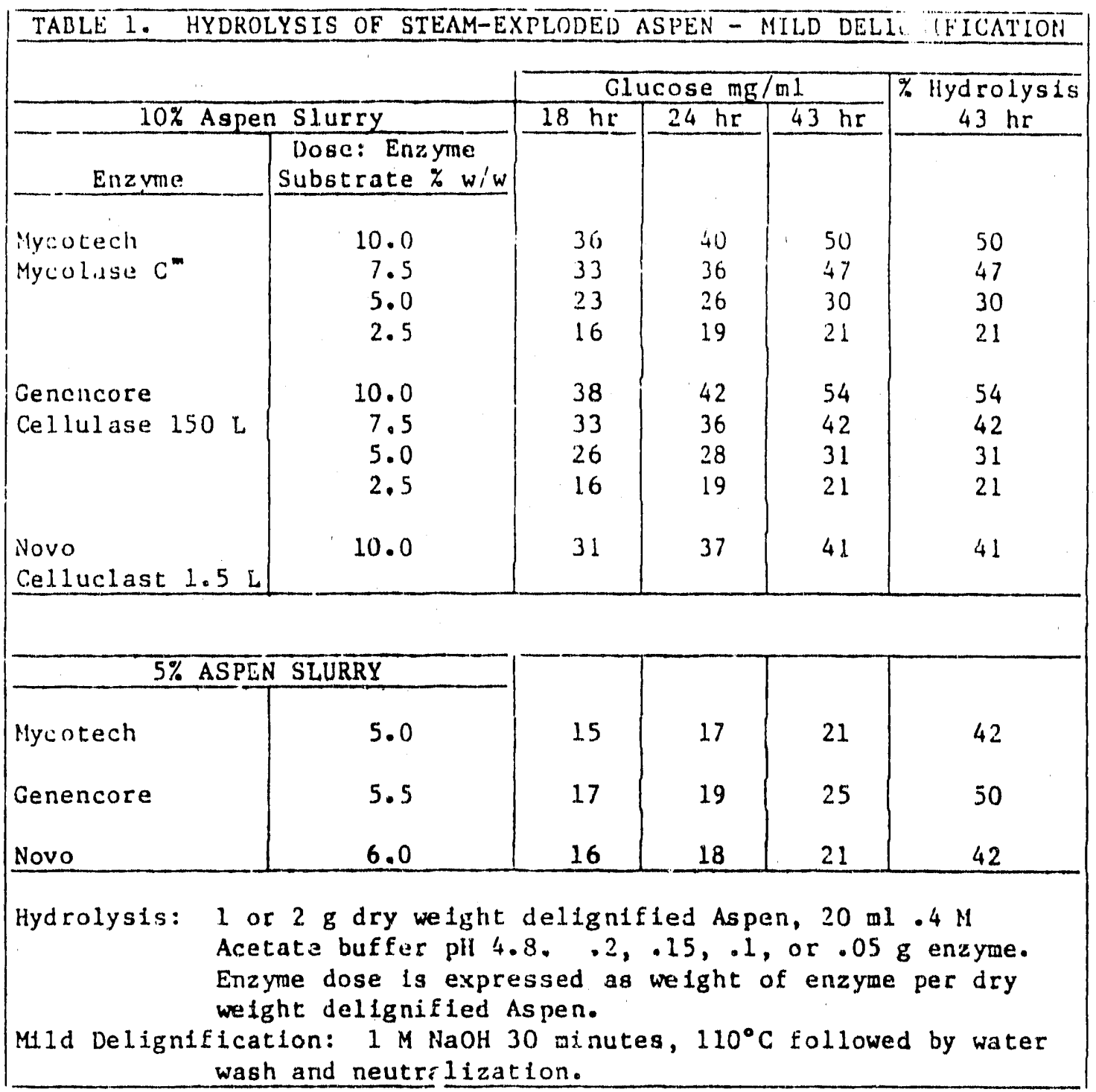

\begin{tabular}{|c|c|c|}
\hline \multicolumn{3}{|c|}{$2.75 \%$ Aspen } \\
\hline Enzyme/Dose & Clucose $\mathrm{mg} / \mathrm{ml} 24 \mathrm{hr}$ & 7 Hydrolysis \\
\hline Mycotech $18 \%$ & 21.5 & 78.2 \\
\hline Genencore $18 \%$ & 23.5 & 85.5 \\
\hline 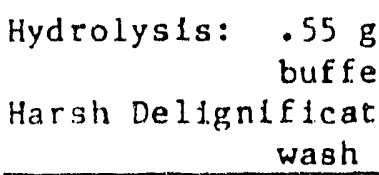 & $\begin{array}{l}\text { welght delignifted Asp } \\
4.8 \text {. } 1 \text { g enzyme. } \\
1 \mathrm{M} \mathrm{NaOH,} 1 \text { hour. } 125 \\
\text { neutrallzatioll. }\end{array}$ & $\begin{array}{l}20 \mathrm{ml} \cdot 4 \mathrm{M} \text { acetate } \\
11 \text { owed by water }\end{array}$ \\
\hline
\end{tabular}


Mycotech's cellulase is evaluated by standard enzyme procedures using filter paper, carboxymethyl cellulose (CMC), cellobiose, and xylan as reaction substrates. A standardized hydrolysis of delignified barley straw is also used as a routine test procedure.

\section{Enzyme Assays}

Enzyme assays are carried out using .05 M acotic acid, sodium acetate buffer $\mathrm{pH}$ 4.8. Both solid and liquid enzyme samples are diluted 1:1000 by weight in buffer. Dilutions are mixed to suspend insoluble material when being dispersed to reaction tubes. Assays are incubated at $50^{\circ} \mathrm{C}$ in a stationary ivater bath for the specified time. For filter paper, CMC and xylan assays, the reaction is stopped by the addition of $2 \mathrm{ml}$, Dinitrosalycilic acid reagent. Tubes are immersed in boiling water for 10 minutes to develop the DNS color reaction. Developed samples are diluted $1: 10$ in water and read at $550 \mathrm{~nm}$. A $4 \mathrm{mg} / \mathrm{ml}$ glucose solution is used as a standard. In cellobiase assay, glucose is determined using a Yellow Springs Instrument enzymatic glucose analyzer.

\section{Filter Paper}

Filter, paper activity is determined using the disc assay method of Montanecourt. In the assay, $.5 \mathrm{ml}$ diluted enzyme and $.5 \mathrm{ml}$ buffer are incubated with one antibiotic disc (Schleicher and Schuell Company) for 120 minutes. Results are expressed as international units (micro mole glucose produced per minute) per gram of cellulase. For comparison with assays using filter paper strips, results are multiplied by a factor of 2.8 as described by Montene-
court.

\section{Carbomethyl Cellulose}

CMC activity is determined using $1 \mathrm{ml}$, $1 \%$ CMC (Sigma Low Viscosity) mixed with 1 ml diluted enzyme sample incubated for 30 minutes. Results are expressed as international units per gram of enzyme.

\section{Cellobiase}

Cellobiase activity is determined using .5 $\mathrm{ml}, 1 \%$ cellobiose (Sigma) and .5 ml diluted enzyme incubated 30 minutes. Results are reported as international units per gram of enzyme. Montenecourt, Antibiotic Discs, An Improvement in the Filter paper Assay for
Cellulase, Biotechnology and Bioengineering, Vol. 20, pp. 297-300. 
$\underline{x y} \operatorname{lin}$

Larchwood xylan (Slgma) is suspended at .5t in buffex. One m 1 xylan suspension is mixed with .5 ml enzyme dilution and .5 ml buffer and incubated for 15 minutes. Results are expressed as my reducing sugar produced per minute per gram of enzyme.

\section{Straw Hydrolysis}

In Mycolase $C$ preparatiots, fellitase is absorbed to insoluble culture solids. This makes accurate analysis by conventional enzyme assay procedures difficult. It is difficult to accurately dispense small aliquotes of enzyme dilution containing suspended solids. Cellulase may not completely desorb from insoluble materials in short reaction times. To overcome these problems and to use a more "real world" substrate, Mycotech developed a stanclardized hydrolysis of delignificd barley straw. In this procedure, enzyme is directly weighed without dilution into the reaction flask and the hydrolysis carried out for 24 hours.

Barley straw (Hector variety from Montana USA) is milled to pass a 20 mesh screen. Straw is delignified by mixing with 15 voluma, $1 \mathrm{M} \mathrm{NaOH}$ (1 ug straw per $15 \mathrm{mg} \mathrm{NaOH}$ solution) and autoclaving for 1 hour at $120^{\circ} \mathrm{C}$. Straw is then washed on an 80 mesh screen unil wash water is clear, transferred to a beaker, suspended in water, and neutralized with a $\mathrm{H} \mathrm{H}_{2} \mathrm{SO}_{4}$. Neutralized water is poured off, and straw is rinsed with water, sczeened and dried at $30^{\circ} \mathrm{C}$.

One gram of delignified straw is suspended in $20 \mathrm{ml} .5 \mathrm{M}$ acetate buffer pH 4.8 in a screw cap $100 \mathrm{ml}$ flask and autoclaved. After cooling, $.100 \mathrm{~g}$ cellulase sample and $.100 \mathrm{~g}$ cellobiase (Novo 188 ) are weighed into the flask. One $m 1$ sodium azide is added to inhibit bacterial growth. Flasks are incubated in a rotary shaking environmental chamber ai 100 strokes/minute and $45^{\circ} \mathrm{C}$. At 24 hours, glucose is determined using a ySI En zymatic glucose analyzer. Cellobiase insures that soluble cellodextrins are converted to glucose. Without the presence of cellulase, Novo 188 does not produce measurable glucose under these conditions.

The reaction is linear over a range of cellulase activity levels to at least 48 hours. The following figure compares Mycolase $C$ and two commercial cellulase preparations at two different enzyme doses over 48 hours. Activity levels of Mycolase $C$ are directly corparable to these comercial preparations. Differences in activity levels in this procedure are much less than in filter paper assays, indicating that standard assay techriques tend to underestimate the activity of the unpurified Mycolase C preparation. In hydrolysis studies using a variety of cellulosic substrates, straw hydrolysis values have provided a more accurate prediction of results than have standard enzyme assiay procedures. 


\section{MYCO TECH}

\section{BioProducts Systems}

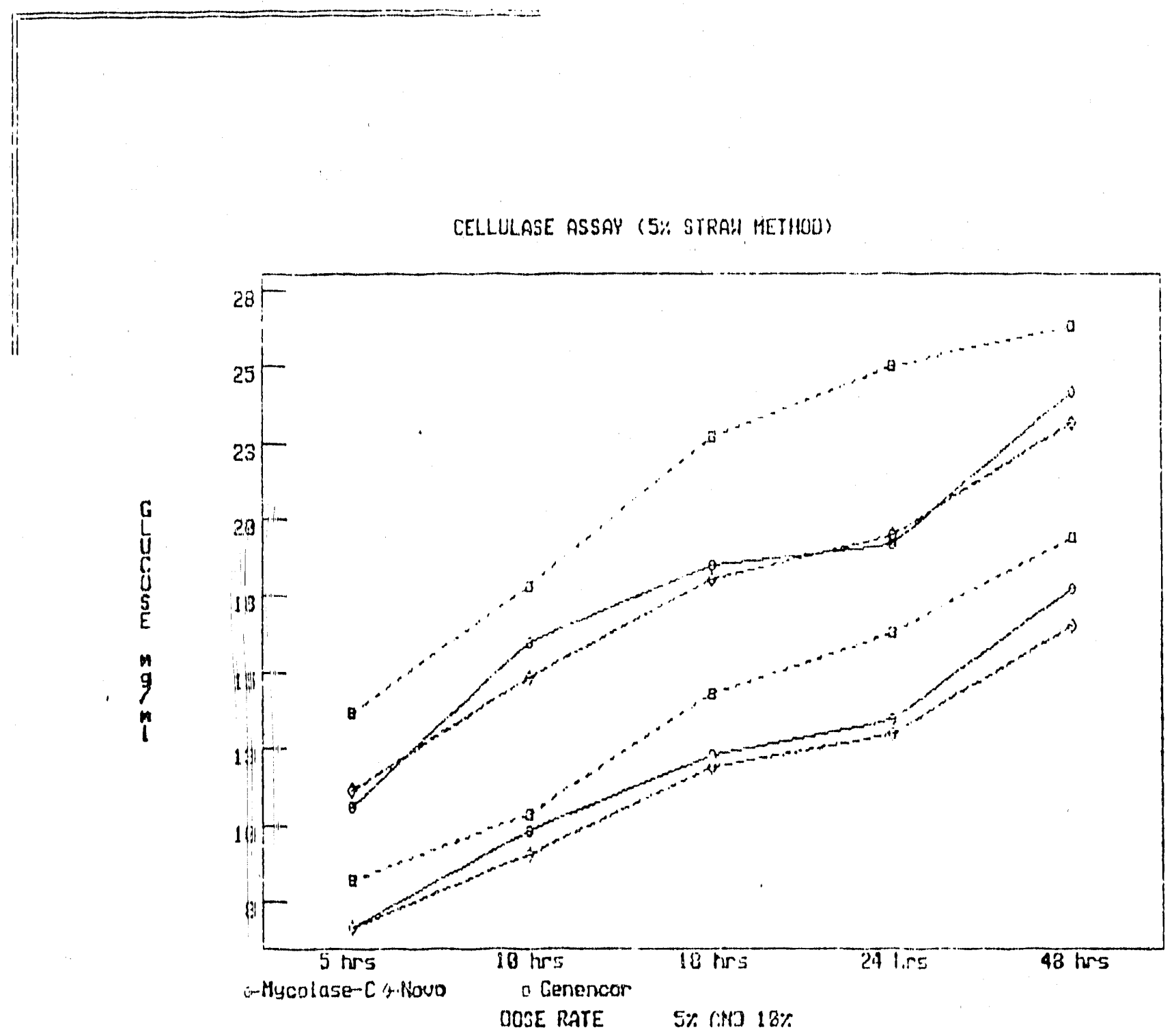

630 Ulah Ave., Butte, MT 59701 $4061182 \cdot 2346$ 

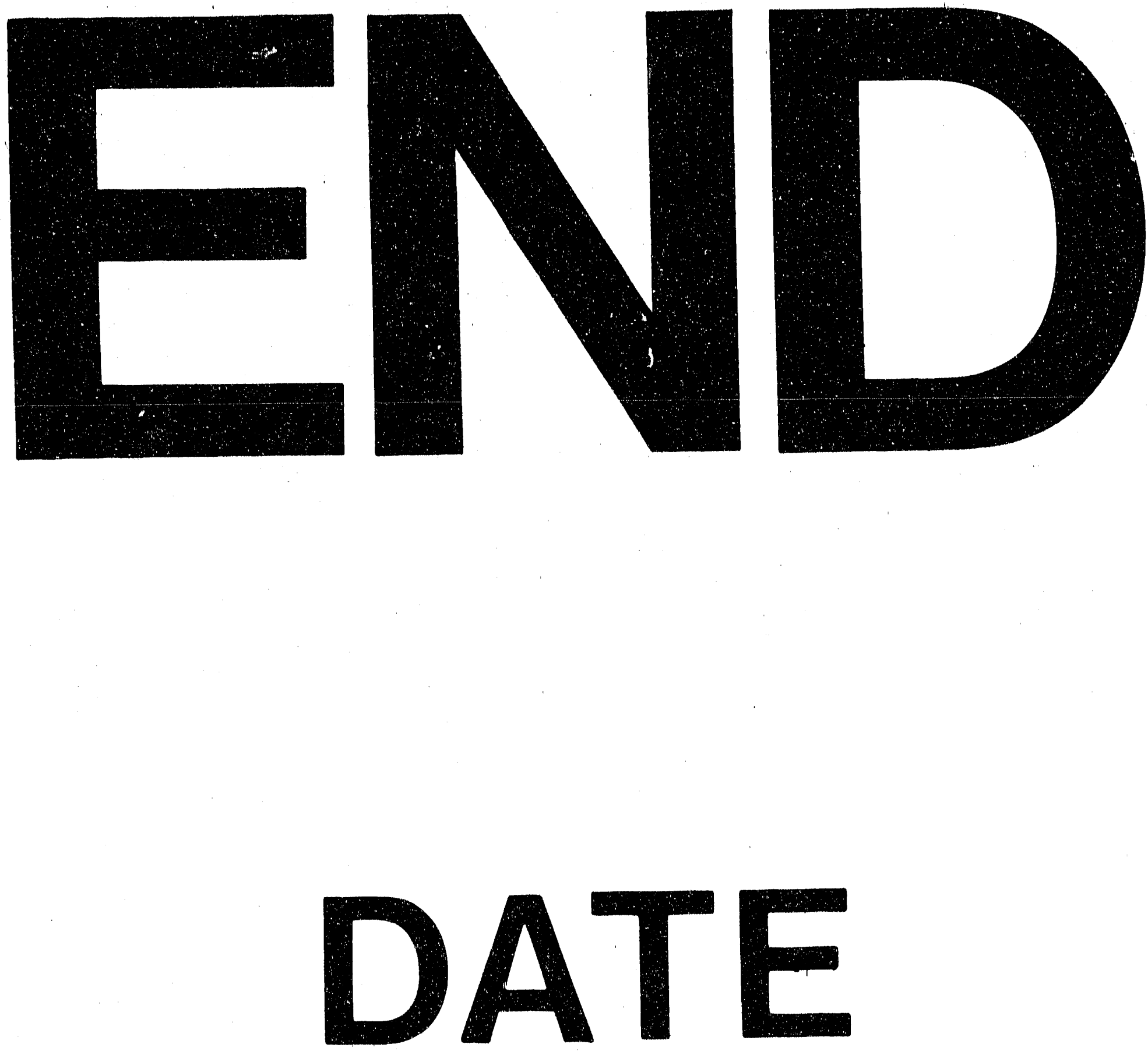

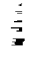
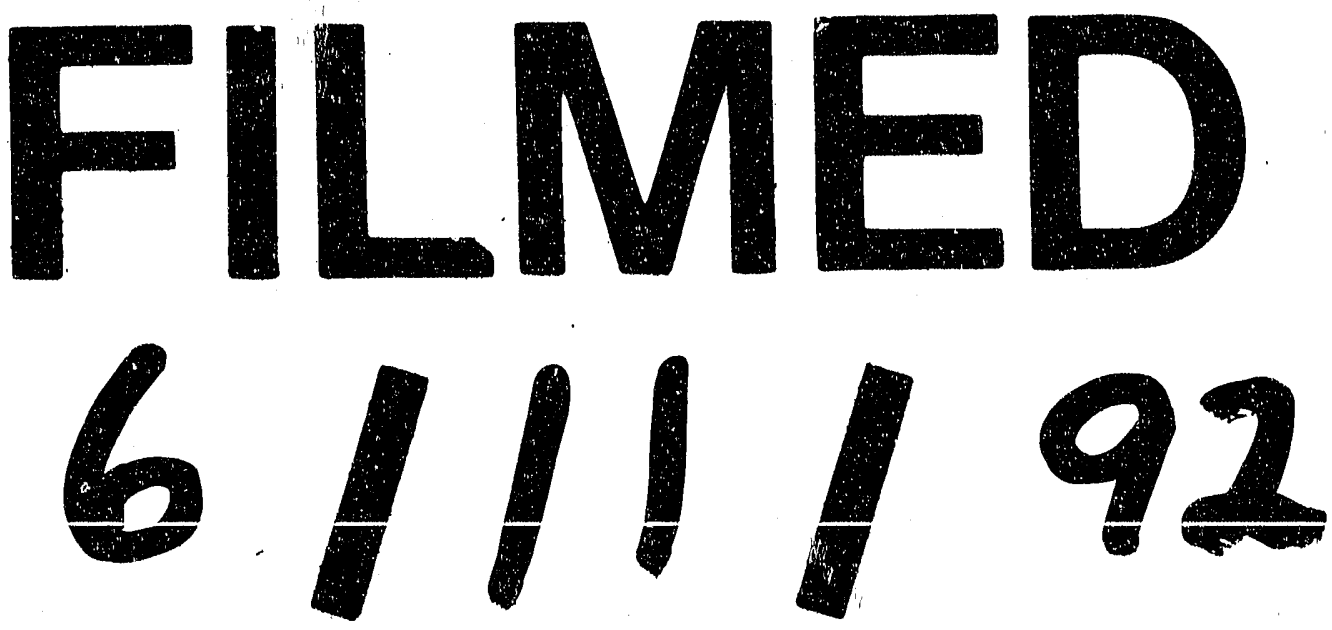
